\title{
MISI DAN PLURALITAS KEYAKINAN DI INDONESIA
}

Dr. Fransiskus Irwan Widjaja, MAIE., M.Th

Noh Ibrahim Boiliu, MTh 


\section{KATA PENGANTAR}

Bersyukur untuk buku MISI dan PLURALITAS KEYAKINAN DI INDONESIA yang boleh diterbitkan. Kami menghadirkan buku ini untuk meresponi masalah kekinian yang dihadapi gereja yakni misi dan pluralsime agama sebagai tantangan global khususnya di Indonesia. Sebagai seorang praktisi misi dan akademisi, Amanat Agung adalah amanat yang hakiki yang tidak bisa di tawar-tawar. Pemberitaan kabar baik untuk semua makluk, penjangkauan dan pemuridan, pertumbuhan iman serta penanaman gereja merupakan tanggung jawab gereja Tuhan. Tetapi di sisi lain, realitas masyarakat Indonesia yang majemuk dengan berbagai keyakinan yang merupakan kumpulan mayoritas adalah ladang misi yang menguning.

Bagaimana meyikapinya? Melalui buku ini, dihadirkan dengan jelas pandangan dan sikap Misi Allah baik di Perjanjian Lama maupun Perjanjian Baru, begitu juga dengan Amanat Agung dan Misi Gereja. Amanat Agung sebagai fondasi misi gereja merupakan kewajiban yang harus di jalankan. Gereja harus fokus pada panggilannya. Permasalahan yang terjadi adalah gereja "sering dianggap sembrono" dalam pendekatan yang sering kali menimbulkan konflik.

Pluralitas keyakinan dalam konteks ke-indonesiaan dijelaskan dalam buku ini sebagai usaha untuk membuka wawasan kekristenan dalam menyikapi pluralitas keyakinan di Indonesia. Kepelbagaian keyakinan dalam negara Pancasila juga menjadi tantangan tersendiri dalam dalam tugas Misi.

Buku ini yang ada di tangan pembaca dapat dibaca oleh kaum awam dan akademisi. Juga dapat menjadi buku wajib, khususnya bagi mahasiswa semua jurusan yang studi di STT Real Batam.

Akhir kata, terima kasih buat rekan sekerja dan sahabat saya Bapak Noh Boiliu yang juga menjadi sahabat dalam tahun-tahun awal berdirinya STT Real Batam dan "motor pendorong" dalam menulis bersama buku ini. 


\section{DAFTAR ISI}

\section{Kata pengantar $\mathrm{i}$}

Bab Satu: Kontinuitas Misi Allah 1
A. Memahami Posisi Israel dalam Misi Allah 1
B. Perjanjian Lama dan Misi Allah 3
C. Perjanjian Baru dan Misi Allah 6
D. Teologia Perjanjian dan Misi Allah 8
1. Konsep dasar dan Istilah Perjanjian 8
2. Sejarah Teologi Perjanjian 11
3. Perjanjian Eden 13
4. Perjanjian Nuh 19
5. Perjanjian Abraham 21

Bab Dua: Amanat Agung Dan Misi Gereja 25
A. Amanat Agung sebagai Fondasi Misi Gereja (Mat. 28:16-20) 25
B. Amanat Agung dalam Kisah Para Rasul 30
C. Misi dan Tanggung Jawab Gereja 33
D. Fokus Misi Gereja 36
E. Misi dan Misionaris 39

\section{Bab Tiga: Misi Dan Pemuridan 45}
A. Pendahuluan 45
B. Pemuridan sebagai Tugas Mengajar 46
C. Memuridkan sebagai Upaya Melahirkan Pemimpin dalam Gereja 49

\section{Bab Empat: Perjumpaan Menuju Pertobatan 55}
A. Permasalahan dan Pendekatan Fenomenologi 52
B. Fenomena Perjumpaan Paulus 57
C. Pra Perjumpaan 61
D. Perjumpaan Pneumatik dengan Kristus: Titik Kulminasi Religiusitas 65

Bab Lima: Pluralitas Keyakinan Dalam Konteks Keindonesiaan 70

A. Manusia dan Agama 
B. Kekristenan dan Pluralitas Keyakinan di Indonesia 70

C. Pluralisme Sebagai Suatu Perubahan 71

D. Dari Pikiran Mitis Hingga Fungsional 72

E. Manusia dan Pluralitas Keyakinan 74

F. Kepelbagaian Keyakinan dalam Negara Pancasila 75

G. Pancasila yang Hirarkis Piramidal 79

H. Kepelbagaian dalam Realitas Praksis Bernegara 80

I. Pluralitas Keyakinan dan Tanggapan 85

J. Kesimpulan 88

\section{Bab Enam: Isu Pluralisme Dan Tantangan Misi 91}
A. Pendahuluan 91
B. Perlunya Teologi Pluralisme 93
C. Pluralisme Agama dan Konflik 98
D. Pluralisme dan Tantangan Misi 102
E. Tanggapan Terhadap Teologi Pluralisme 103 


\section{BAB SATU \\ KONTINUITAS MISI ALLAH}

\section{A. Memahami Posisi Israel dalam Misi Allah}

Memahami posisi bangsa Israel dalam peta visi Allah atas dunia merupakan sebuah pintu masuk untuk memahami kehendak Allah atas gereja. Urgensitas pemahaman kita atas posisi Israel dalam peta visi Allah adalah agar gereja mengerti maksud pemanggilan, penetapan dan pengutusan Tuhan atas Israel; mengerti reaksi dan aksi Israel dalam menjalani misi tersebut. Memahami panggilan Allah atas Israel merupakan langkah awal dalam memahami peta misi Allah sebab "from Genesis to Malachi Jehovah is portrayed as a missionary God. The Jesus of the New Testament is the Jehovah of the Old. He was the first and great Missionary...".1 Perintah misi berkaitan dengan bagaimana manusia tetap berada di dalam hubungan dan komunikasi dengan Allah. Allah memanggil Israel dan nantinya gereja, adalah agar yang terputus hubungannya dengan Allah dapat mendengar berita misi dan kembali membangun hubungan dengan Allah. Sebab, sejak awal, Allah menciptakan manusia untuk diriNya. "Man was created in the beginning not only by God but for God". ${ }^{2}$

Menurut Kane, ada tiga tujuan pilihan Allah atas Israel saat kita melihatnya dalam konteks misi, yakni " first, Israel was to be the recipient and guardian of God's special revelation to the world (Heb. 1:1-3). Second, Israel was to be the channel through which the Redeemer was to enter the stream of human history. Third, Israel was to be God's servent and witness in the midst of the nations". ${ }^{3}$ Tujuan ini, oleh Harold Cook ${ }^{4}$ juga berkaitan dengan sepuluh hukum Allah (the ten commandments) sebagai bukti legal (legalitas itu dapat

\footnotetext{
${ }^{1}$ Herbert Kane J. The Christian World Mission. Today and Tomorrow (Michigan: Baker Book House, 1986), 16.

2 Ibid.

${ }^{3}$ Ibid.

${ }^{4}$ Harold Kook, An Introduction to Christian Missions (USA: Moody Press, 1974), 61.
} 
dilihat melalui adanya tempat diberikan dan 10 hukum itu sendiri) bahwa Allah telah memilih dan mengutus mereka bahkan Allah pernah berbicara kepada mereka.

Ketika Israel menerima panggilan tersebut melalui Musa, Israel pada umumnya pada waktu masih berada di Mesir, mereka hanya mengarahkan pandangannya pada bagaimana memperoleh kemerdekaan dari Mesir. Atau pun ketika Musa menyampaikan visi Tuhan atas mereka tentang Kanaan sebagai tujuan akhir mereka, mereka hanya mengerti berita tersebut sebatas "bebas dan memiliki negeri”. Pandangan semacam ini tentu akan mengarahkan mereka hanya sebatas memiliki negeri sendiri sehingga mereka menjadi setingkat dengan bangsa-bangsa lain di sekitarnya.

Pemikiran yang diungkapkan di atas dapat ditelusuri dari sikap dan reaksi Israel ketika Musa menyampaikan visi tersebut pertama kalinya bahkan sikap dan reaksi lainnya dapat ditelusuri ketika proses keluar dari Mesir, memasuki dan menetap di Kanaan.

Sikap dan reaksi umum yang dapat dijumpai adalah menafikan panggilan Allah atas mereka sebagai misionaris. Penafikan tersebut dapat dilihat dari sikap mereka untuk tidak terpaut kepada Tuhan, tegar tengkuk, dan lain-lain. Sikap-sikap ini menunjukkan bahwa mereka tidak memiliki tanggungjawab misi atau tidak melihat posisi mereka sebagai misionaris Tuhan di tengahtengah bangsa kafir.

Berkaitan dengan mandat misi Allah kepada Israel, maka kita dapat mengerti konsep misi. Konsepnya adalah setiap orang yang belum mengenal Allah baik dalam konteks Perjanjian Lama maupun Perjanjian Baru harus mengenalnya melalui Israel (PL) dan melalui gereja Tuhan (PB). Wilayahnya meliputi seluruh dunia yakni yang belum mengenal dan menerima Tuhan (Kristus).

Israel dalam Perjanjian Lama dan gereja dalam Perjanjian Baru, samasama mengemban tugas sebagai misionaris. Ini berarti bahwa mereka harus melaksanakan mandat. Dalam konteks Perjanjian Lama, tidak ada keharusan 
untuk menjadi warga Israel sebagai representasi berada di dalam "Tuhan". Melainkan menunjukkan melalui sikap tunduk dan menyembah hanya kepada YHWH. Sedangkan di Perjanjian Baru, memang tidak ada keharusan untuk berada di dalam gereja namun tidak mungkin mengenal Allah dan menandainya jika tidak di dalam gereja. Ini berarti bahwa tidak ada jaminan bahwa yang berada di dalam gereja "pasti selamat", sejalan dengan itu juga tidak mungkin ada jaminan pengajaran yang benar jika tidak "di dalam gereja".

Misi bukanlah tugas pertama dan terakhir melainkan misi ada di dalam proses menjadi milik Kristus seutuhnya. Yakni, yang telah mengenal Allah (Kristus, baik PL maupun PB) di pundaknya tugas misi diletakan. Ini berarti semua orang percaya adalah misionaris. Proses selanjutnya adalah menjadikan semua murid Kristus, yakni yang telah mengenal dan menerima Kristus.

\section{B. Perjanjian Lama dan Misi Allah}

Ada kesalahpahaman yang populer bahwa Perjanjian Lama (PL) tidak memiliki suatu mandat misi dan bahwa Perjanjian Lama didedikasikan hanya bagi orang Yahudi dan sejarah Yahudi. Akan tetapi, pandangan tersebut tidak sesuai dengan klaim yang dibuat oleh Perjanjian Lama itu sendiri. Bahkan jika membatasi penyelidikan kita kepada tiga teks kunci dalam Perjanjian Lama, kita akan langsung dapat melihat bahwa ketiga teks ini menghadirkan beberapa pernyataan panggilan misi yang paling kuat yang bisa ditemukan di mana pun di Alkitab.

Jika kita memperhatikan dengan saksama permulaan dari Perjanjian Lama maka kita tidak cepat menilai bahwa Perjanjian Lama tidak memiliki tantangan misi. Pesan dalam pasal-pasal terawal Kitab Kejadian adalah universalitas ruang lingkup dan globalnya audiensi. Bukankah Allah berurusan dengan "semua kaum di muka bumi" ketika Allah bertindak dalam anugerah yang menyelamatkan di ketiga titik penghubung spesifik dalam Kejadian 1-11? Sejak kejatuhan manusia, air bah di bumi dan kegagalan menara Babel, Allah mengarahkan pesan agung mengenai keselamatan kepada seluruh umat 
manusia (Kej. 3:15; 9:17; 12:1-3). Bavink mengatakan bahwa "Genesis 1:3 and Genesis 10, as well as Paul's statement that God 'hath made of one blood all nations of men for to dwell on all the face of the earth' (Acts 17:26), have therefore an outstanding significance on the mission field". ${ }^{5}$

Jika kita meragukan bahwa janji Allah kepada Abraham (Kej. 12:1-3) adalah global ruang lingkupnya dan universal dalam penawarannya, kita harus memperhatikan bahwa "bangsa-bangsa" yang terpencar di seluruh bumi muncul di Kejadian 10, di dalam apa yang sering disebut “Tabel Tujuh Puluh Bangsa”. Daftar seluruh bangsa, bahasa dan kaum merupakan latar belakang bagi janji Allah untuk memberkati "semua kaum di seluruh bumi” dalam Kejadian 12:3.

Ada tiga teks dasar yang bisa menjelaskan mandat misi yang telah Allah rancang bagi seluruh bangsa Israel: Kejadian 12:1-3, Keluaran 19:4-6, dan Mazmur 67. Kita tidak mungkin mengerti Perjanjian Lama secara akurat tanpa menyelidiki ketiga teks ini dalam konteks misi.nya. Di dalam rencana dan tujuan Allah, Israel selalu bertanggung jawab untuk mengomunikasikan pesan anugerah Allah kepada bangsa-bangsa. Bangsa Israel dimaksudkan untuk menjadi suatu bangsa pemberita.

Agar jangan kita berpikir bahwa ketiga teks Perjanjian Lama ini memberi mandat hanya kepada orang-orang pada masa itu saja dan karena itu sama sekali tidak relevan bagi kita yang hidup di era Kristen, maka perlu dijelaskan bahwa ketiga teks tersebut juga merupakan panggilan Allah bagi kita:

1. Memberitakan Rencana Allah untuk Memberkati Bangsa-bangsa (Kej. 12:3).

2. Berpartisipasi dalam Keimamatan Allah sebagai Agen-Agen dari Berkat itu (Kel. 19:4-6).

3. Membuktikan Maksud Allah untuk Memberkati Semua Bangsa (Mzm. 67).

Tidak seorang pun bisa berkata bahwa Perjanjian Lama dimulai secara etnosentris atau Allah dalam Perjanjian Lama begitu pro Yahudi sehingga

5 J.H. Bavink, An Introduction to the Science of Missions (New Jersey: P\&R Publishing, n.d), 13 . 
penjangkauan misi tidak terjadi sampai pada bangsa-bangsa bukan Yahudi. Kejadian 1-11 dengan jelas membuktikan hal yang sebaliknya. Ruang lingkup dari pasal-pasal ini adalah seluruh dunia dalam hal tawaran keselamatan bagi semua orang yang mau percaya. Tema yang bertentangan dalam pasal-pasal yang sama ini adalah usaha bangsa-bangsa untuk mencari "nama" bagi diri mereka sendiri. Baik Kejadian 6:4 maupun Kejadian 11:4, tujuan tunggal dari umat manusia adalah mendapatkan "nama" bagi diri mereka dan memajukan reputasi mereka sendiri - dengan mengorbankan "nama" Allah.

Perkataan anugerah ketigalah yang relevan di sini karena menekankan anugerah Allah mengatasi kegagalan manusia dan usaha sesat mereka untuk mendapatkan "nama" atau reputasi bagi diri mereka sendiri. Lima kali Allah berkata, "Aku akan memberkati engkau", "Aku akan memberkati orang-orang yang memberkati engkau," dan "olehmu semua kaum di muka bumi akan mendapat berkat". Meski demikian, pemilihan (boleh kita melihatnya sebagai suatu anugerah) Israel tidak serta merta membuat mereka "besar kepala". "If Jehovah is the God of Israel because he has made a covenant with Israel, it is conceivable that other nations will also some day be included in that covenant. For Israel has no individual and peculiar claim upon God its privileged position is due solely tod God's electing grade. Israel is not better than other nation"6. Israel boleh merasakan pemilihan tersebut secara sendiri dalam konteks kesejarahan pemilihan dalam perjanjian (covenant) namun bergerak maju dan menjadi bagian semua bangsa yang mau mengenal Allah.

Sangat jelas bahwa kata kuncinya adalah memberkati (berkat). Kata yang sama ini menandai seluruh bagian ini, dimulai dengan perkataan kepada Adam dan Hawa: "Dia memberkati mereka dan berkata, "Beranakcuculah dan bertambah-tambah banyak", sama seperti Dia juga dengan murah hati berjanji untuk memberkati binatang-binatang.

Bangsa-bangsa akan diberkati melalui "keturunan" orang ini, merujuk kepada keturunan-keturunannya. "Sesungguhnya, keturunan" perempuan (Kej.

${ }^{6}$ Ibid., 14. 
3:15), "keturunan" Sem di kemah di mana Tuhan mau datang dan berdiam (Kej. 9:27) dan "keturunan" Abraham semua membentuk suatu keutuhan kolektif. Entitas kolektif ini ditandai oleh serangkaian perwakilan yang berperan sebagai jaminan di muka untuk berkat tersebut sampai Kristus sendiri muncul dari garis keturunan yang sama sebagai bagian dari rangkaian dan entitas korporat tersebut.

\section{Perjanjian Baru dan Misi Allah}

Para pujangga dan filsuf Yunani kuno merindukan suatu masyarakat ideal dan memimpikan suatu zaman keemasan yang hilang di masa lampau. Tetapi mereka tidak melihat kecemerlangan pada masa kini atau pengharapan bahwa masa depan seperti itu dapat terjadi. Iman Ibrani-Kristen menyatakan pengharapannya dalam istilah Kerajaan Allah. Pengharapan alkitabiah ini tidak seperti mimpi para pujangga Yunani.

Sebaliknya pengharapan ini dinyatakan oleh Allah dan berakhir dalam Dia. Ide alkitabiah tentang Kerajaan Allah berakar secara mendalam pada Perjanjian Lama. Ide tersebut didasarkan pada keyakinan bahwa ada satu Allah yang kekal dan hidup yang telah menyatakan Diri-Nya kepada manusia. Allah tersebut juga telah menyatakan bahwa Dia memiliki tujuan bagi umat manusia yang telah dipilih-Nya untuk dicapai melalui Israel. Maka para nabi mengabarkan suatu hari ketika manusia akan hidup bersama dalam damai. Allah kemudian akan menjadi hakim antara bangsa-bangsa dan akan menjadi wasit bagi banyak suku bangsa; maka mereka akan menempa pedangpedangnya menjadi mata bajak dan tombak-tombaknya menjadi pisau pemangkas; bangsa tidak akan lagi mengangkat pedang terhadap bangsa, dan mereka tidak akan lagi belajar perang (Yes. 2:4).

Masalah yang ada dalam masyarakat tidak hanya akan diselesaikan, tetapi kejahatan dalam lingkungan fisik manusia juga tidak akan ada lagi. Serigala akan tinggal bersama domba dan macan tutul akan berbaring di 
samping kambing. Anak lembu dan anak singa akan makan rumput bersamasama, dan seorang anak kecil akan menggiringnya (Yes. 11:6).

Damai, keamanan, kenyamanan - semuanya dijanjikan di masa depan.Kemudian datanglah Yesus dari Nazaret dengan pengumuman ini, "Bertobatlah, sebab Kerajaan Sorga sudah dekat!" (Mat. 4:17). Tema kedatangan Kerajaan Allah ini sentral dalam misi-Nya. Pengajaran-Nya dibuat untuk menunjukkan kepada manusia bagaimana mereka bisa masuk ke dalam Kerajaan Allah (Mat. 5:20; 7:21). Pekerjaan Allah yang hebat dimaksudkan untuk membuktikan bahwa Kerajaan Allah telah datang ke atas mereka (Mat. 12:28). Berbagai perumpamaan Kristus mengilustrasikan kepada para muridNya kebenaran tentang Kerajaan Allah (Mat. 13:11). Ketika Dia mengajarkan para pengikut-Nya untuk berdoa, pada inti permohonan mereka ada kalimat, "datanglah Kerajaan-Mu, jadilah kehendak-Mu di bumi seperti di sorga" (Mat. 6:10). Menjelang kematian-Nya, Dia meyakinkan para murid-Nya bahwa Dia akan memberikan kebahagiaan pada mereka dan persekutuan dari kerajaan Allah (Luk. 22:22-30). Dia berjanji bahwa Dia akan datang kembali ke bumi dalam kemuliaan untuk membawa berkat-berkat Kerajaan Allah bagi mereka yang sejak semula telah disediakan (Mat. 25:31, 34).

Ketika kita berbicara tentang misi dan Perjanjian Baru 7 , maka keduanya saling berkaitan. Dengan kata lain Perjanjian Baru tidak dapat dilepaskan dari tindakan misi. Ini berarti orang percaya tidak dapat dilepaskan dari misi. Bahkan, "Christianity, if it is real Christianity, must of necessity be missionary...it is strange until we realize that many people's ideas Christianity have only a remote connection with the New Testament" 8 . Kekristenan, misi dan pemuridan saling berkaitan. Tentang misi dan pemuridan akan dijelaskan pada bab berikutnya.

Bahkan Perjanjian Baru merupakan kelanjutan misi Allah. Allah memanggil Israel ke Kanaan karena Allah mempunyai tujuan atas Israel. Allah

${ }^{7}$ Cock, An Introduction to Christian Missions, 31-58.

8 Ibid., 19. 
menetapkan Kanaan sebagai tujuan akhir perjalanan Israel. Mereka diizinkan memiliki Kanaan bukan hanya untuk ditempati melainkan menempatinya dan menjadikan diri serta bangsa mereka sebagai rule model dalam iman kepada Allah. Ini berarti ada unsur kerugma atau unsur pemberitaan atau memberi kesaksian kepada bangsa lain yang belum mengenal Allah.

\section{Teologia Perjanjian dan Misi Allah}

\section{Konsep Dasar dan Istilah Perjanjian}

Teologia Kovenan adalah keunikan dari teologia Alkitab yang memiliki akar pengertian berdasarkan penyataan Allah di dalam firmanNya. Dapat dikatakan bahwa Alkitab mengungkapkan prinsip ini di seluruh bagiannya, baik di dalam Perjanjian Lama maupun Perjanjian Baru. Itulah sebabnya pengertian teologia kovenan ini tidak lepas dari usaha hermeneutik, penafsiran Alkitab. Usaha hermeneutik yang bertanggung jawab pada akibatnya akan melihat Alkitab sebagai sebuah sistem kebenaran, dalam arti sebuah pokok permasalahan tertentu yang muncul di dalamnya harus memiliki konsistensi prinsip. Hal ini pada akibatnya, tidak saja melihat kesatuan Alkitab sebagai firman Allah yang tertulis, melainkan juga kepada pengenalan akan diri Allah sendiri. Dengan kata lain, Teologia Kovenan memberi nilai dari kehidupan iman sejati sesuai dengan maksud dan rencana Allah di dalam kehidupan orang percaya. Jika demikian, apakah yang dimaksud dengan teologia kovenan itu? Mengapa kemudian mempunyai dampak praktis serius di dalam kehidupan Kristen sejati?

Bangunan iman Kristen dibangun atas dasar teologia kovenan, maka jika kehidupan Kristen (baca: "Gereja") tidak lagi menempatkan teologia kovenan menjadi pusat teologianya, maka gereja telah kehilangan inti imannya. Gereja yang sedemikian telah kehilangan esensi dan arah keberadaannya di tengahtengah dunia ini. Pada akibatnya akan mengalami kesulitan yang besar di dalam perjuangannya sebagai saksi Kristus dan akan lebih mudah berkompromi dengan berbagai macam sistim pemikiran dunia yang tidak menurut Kristus. 
Harus diakui bahwa pembahasan mengenai teologia kovenan ini sangat luas dan menyangkut aspek-aspek praktis yang dapat diteliti satu demi satu. Karena itu pembahasan ini hanya menyangkut pengertian perjanjian baik Perjanjian Lama maupun Perjanjian Baru, sejarah teologi covenan dari perjanjian edenik, Noahik dan Abrahamik kovenan sebagai perjanjian tertinggi (the higest covenant).

Istilah Perjanjian dalam Perjanjian Lama. Dalam Perjanjian Lama, istilah perjanjian disebut juga dengan berit. Berit berarti suatu ikatan perjanjian khusus (special covenant). Ikatan ini dapat berlaku pada level yang sama maupun dalam level yang berbeda (secara hirarkis). Istilah berit dalam konteks ini lebih mengacu pada suatu ikatan yang tidak se-level, yakni antara Allah dan manusia. Di sini gagasan bilateral tidak ada. Gagasan mengenai berit (ikatan) datang dari Allah, bukan manusia. Artinya Allah mau mengikatkan diri dengan manusia. Ikatan ini, disusun, ditetapkan, dan dikerjakan oleh Allah dan ikatan ini bersifat kekal.

Dari penjelasan di atas, nampak bahwa kata berit merupakan kata benda femenim Tunggal dan secara umum berlaku pada dua level, yakni: 1) Tingkatan pertama manusia dengan manusia (man to man) adalah tingkatan perjanjian teman dengan teman (setara). Istilah-istilah yang dipergunakan adalah persekutuan, perkumpulan, perserikatan (alliance, league). 2) Tingkatan perjanjian antara raja dengan rakyat (tidak setara). Istilah yang dipergunakan adalah constitution dan ordinance (monarc to subject). Perjanjian pernikahan (marriage). Istilah yang dipergunakan adalah alliance (artinya persekutuan, perserikatan). Tingkatan kedua adalah tingkatan perjanjian antara Allah dengan manusia. Dalam perjanjian ini, kedua belah pihak tidak selevel dan berada pada status yang sangat berbeda. Ini merupakan ikatan perjanjian antara Tuhan dengan manusia. Tuhan sebagai pribadi yang kudus rela mengikatkan diri dengan manusia melalui berit/perjanjian. Ia menginginkan agar melalui perjanjian, semua hal (anugerah, keselamatan, berkat, 
perlindungan, kasih sayang, kekudusan) yang ada pada-Nya dapat diimpartasikan kepada manusia.

Istilah Perjanjian dalam Perjanjian Baru. Dalam teks-teks Perjanjian Baru, istilah perjanjian muncul dalam dua bentuk, pertama; diatheke (kata benda), berarti kontrak, perjanjian, surat wasiat atau perjanjian (contract, testament, covenant). Misalnya, teks Galatia 3:15. Dalam teks asli Galatia 3:15, ...nomos anthropos diatheke- kuroo- oudeis atheteo- epidiatassomai (...tetapi bila seseorang membuat ikatan perjanjian dan sudah disahkan, tidak ada orang yang membatalkan atau menambahkan (mengubahnya lagi) sesuatu. Artinya secara hukum, perjanjian itu legal/sah atau dengan kata lain tidak dapat digangu gugat. "Inisiatif datang dari pihak yang memiliki kedudukan yang lebih tinggi dan tidak bersyarat". 9 Istilah diatheke kadang langsung dihubungkan dengan istilah diatithemai dari Sang pembuat perjanjian ( diatithemi berbentuk kata kerja : membuat, menentukan, mengadakan/appoint and make). Misalnya, teks asli Ibrani 8:10, “...Hoti ho diatheke- hos diatithemai ho oikos Israet” (untuk itulah perjanjian ini Aku buat..). Dalam teks ini, kedua istilah (diatheke dan diatithemai) muncul bersamaan sebagai kata benda dan kata kerja. Di sini, Allah bertindak sebagai pembuat perjanjian (diatheke) dan berhak menetukan syarat dan ketentuan/aturan/hukum perjanjian yang berlaku. But we must know that the covenant is the unconditional covenant and this statement represent God feeling to the its people.

Dalam diatheke dan diatithemai, tidak ada gagasan persetujuan bilateral sama sekali. Seperti dalam teks Ibrani 8:10 "Maka inilah perjanjian yang Kuadakan dengan kaum Israel sesudah waktu itu," demikianlah firman Tuhan...(TB). Di sini perjanjian disusun dan ditetapkan oleh Allah (unconditional). Pemegang wasiat memiliki hak penuh atas surat wasiat tersebut bahkan berhak penuh untuk memberikan kepada siapa ia kehendaki. Namun, si penerima tidak harus memenuhi syarat-syarat tertentu. Kata yang

9 John S. Dana, Teologi Perjanjian Lama 1. Catata Kuliah (Surakarta : STT Berita Hidup, 2005), 7. 
kedua suntheke. Suntheke memiliki pengertian "suatu perjanjian yang dibangun atas dasar inisiatif bersama, sederajat, bersyarat dan kedua belah pihak harus tunduk"10 (covenant conditional the to subject and this is the absolut) pada syarat perjanjian dan ini mutlak.

Dari dua istilah ini, kita melihat bahwa Allah sendiri yang mengambil inisiatif (berit dan diatheke) membuat perjanjian dengan manusia. Ia rela, tanpa melihat status ke-Allah-an-Nya, mau mengikatkan diri dengan umat-Nya dalam perjanjian (berit dan diatheke). Ini merupakan tindakan yang luar biasa dan fantastis. Dalam bukunya "The Religion of Israel" Henry Renckens mengatakan bahwa Tuhan memberikan suatu wahyu yang baru dan Ia menikmati hubungan itu bahkan Ia memberikan kepada mereka suatu orientasi baru dalam hidup mereka. "All that could be said of the new god of revelation was that he enjoyed a special relationship with certain individual person, by reason of the fact that he had given a new orientation to their lives, in this respect he was the god of Abraham". ${ }^{11 D i a}$ yang memberikan orientasi baru adalah Tuhanya Abraham.

\section{Sejarah Teologi Perjanjian}

Dalam menggambarkan "perjanjian" yang digunakan dalam teologia maka adalah baik untuk meninjau ulang dengan singkat sejarah dari terimonologi ini. Menurut Morton Smith dalam artikelnya, "The Church and covenant Theology" mengemukakan bahwa:

A mutual promise and agreement, between God and men, in which God gives assurance to men that he will be merciful to them And, on the other side, men bind themselves to God in this covenant that they will exercise repentance and faith... and render such obedience as will be acceptable to $\operatorname{Him}^{12}$

Tuhan membangun suatu hubungan yang timbal balik (Tuhan-manusia) dan Tuhan memberikan kemurahan kepada siapa Ia bermurah hati. Di sini

\footnotetext{
10 John Dana, Teologi Perjanjian Lama, 18.

${ }^{11}$ Henry Renckens, The Religion of Israel, (New York: Seed and Ward, 1965), 63.

12 Morton Smith, The Church and covenant Theology. https://www.apuritansmind.com. Diakses, 26 Juni 2016.
} 
manusia pun mengikatkan diri dengan Tuhan dalam perjanjian sehingga mereka (umat) dapat melatih diri dalam perubahan diri, iman dan ketaatan. Konsep perjanjian semacam ini digunakan untuk menguraikan hubungan seperti hubungan perkawinan dan fakta bahwa perjanjian bukan hanya suatu kontrak yang sah secara hukum tetapi adalah juga suatu hubungan penuh kasih, suatu hubungan persekutuan yang kontinyu antara kedua belah pihak. Ini yang nantinya akan muncul dalam konsep Kristus sebagai mempelai lakilaki dan gereja sebagai mempelai wanita. Ini yang juga dikatakan oleh Smith, bahwa, "the covenant concept is used to describe the marriage relationship, and as such it speaks to us of the fact that the covenant is not just a legal contract but is also a loving relationship, a continuous fellowship between the parties involved". ${ }^{13}$

Dalam mempelajari perjanjian ilahi secara umum, satu hal yang menapak bagi kita adalah rencana penebusan Tuhan dan ini merupakan keselamatan kekal. Tuhan dalam kemahatahuan-Nya dan telah ada dalam blue print-Nya dengan satu tujuan dan rencana untuk umat manusia sejak kejatuhan manusia untuk memulihkan kembali umat-Nya melalui Yesus Sang Mesias. Di dalam terminologi alkitab tentang perjanjian, Allah adalah agen yang utama dalam sejarah penyelamatan. Di mana Tuhan mengungkapkan diri-Nya sebagai Tuhan perjanjian.

Istilah perjanjian sering kali kita jumpai baik dalam Perjanjian Lama maupun Perjanjian Baru. Istilah ini merupakn istilah sekuler namun diberi arti dan makna rohani atau tekhnis khusus, misalnya perjanjian antara Daud dan Yonatan, tentang kontrak komersial, bahkan pakta perjanjian antar negara. Alkitab mengambil kata yang sehari-hari digunakan orang dan memberinya arti khusus.

${ }^{13}$ Morton Smith, The Church and covenant Theology. https://www.apuritansmind.com. Diakses, 26 Juni 2016. 
Dasar dari perjanjian antara Allah dan manusia merupakan prakarsa Tuhan dan bukanlah perundingan. Sebab bila dasarnya adalah perundingan maka bisa saja salah satu pihak tidak setuju karena berbagai hal berkaitan dengan perjanjian yang akan dibangun dan batal. Namun di sini berbeda. Tuhan berdaulat membuat perjanjian, kemudian Ia mencari orang yang tepat menurut pemandangan-Nya dan membangun pakta perjanjian dengan orang tersebut (manusia). Hal ini juga sama dengan keselamatan. Tuhan tidak merundingkan soal keselamatan. Perjanjian semacam ini boleh kita sebut suatu perjanjian yang asimetris bukan simetris.

Sekalipun ini prakarsa ilahi, perjanjian selalu dua sisi. Sebab perjanjian itu berjalan atau tidak, ini kembali pada tanggapan manusia karena free will. Tetapi kita harus ingat bahwa bukan berarti Tuhan tidak mampu menggerakan manusia untuk menerima janji tersebut. Contohnya, Perjanjian Abraham di pasal 17 dari kitab Kejadian, di sana kita menemukan suatu penekanan yang jelas pada bagian yang dimainkan oleh Iman Abraham. Iman Abraham menjadi "The important part in covenant or faith is the basic element in covenant". Iman Abraham, membawa Abraham pada satu keyakinan bahwa perjanjian yang ia buat dengan "pribadi yang Maha Kudus itu" berbeda dengan "pribadi-pribadi yang lain yang menganggap diri dan dianggp sebagai "Tuhan". Tidak ada perjanjian tanpa respons dari manusia. Salah satu contoh, teks Yohanes 3:16 di sana dicatat bahwa "Karena Allah begitu mengasihi manusia di dunia ini, sehingga Ia memberikan Anak-Nya yang tunggal, supaya setiap orang yang percaya kepada-Nya tidak binasa, melainkan mendapat hidup sejati dan kekal-BIS". Dalam teks ini antara inisiatif Allah (God's loved the world is the representing initiative of God) dan respons manusia (setiap orang yang percaya kepada-Nya tidak binasa melainkan ...). Muncul bersamaan. Dalam teks ini keselamatan hanya dinikmati oleh mereka yang "percaya -karena respon iman".

\section{Perjanjian Eden (penciptaan)}

Saya memulai sejarah teologi perjanjian dengan teologi proper, bahwa Allah adalah satu pribadi yang ada dengan sendirinya, Ia ada, kudus, tak 
terlihat dan kekal. Ia memiliki sifat dan sifat yang dimilikinya tidak berdiri sendiri atau terpisah-pisah bahkan sifat yang satu tidak mengungguli sifat-Nya yang lain.

Allah merupakan satu pribadi yang "misteri”. Sebelum Kejadian 1:1 dan selanjutnya tidak ada seorang pun yang mengetahui tentang Allah dan keberada-an-Nya (being). Meskipun Ia tidak dikenal (sebelum Kejadian 1:1 dst) namun Ia ada. Mulai Kejadian 1:1, yakni "pada mulanya 'Allah' menciptakan langit dan bumi" maka kita dapat mengetahui adanya satu pribadi yang kudus, ada dengan sedirinya (tak berawal dan tak berakhir) tak terlihat dan namun kekal. Kejadian 1:1 merupakan langkah awal Allah menyatakan diri. Istilah ini oleh para teolog disebut penyataan Allah. "Penyataan Alah ialah tindakan Allah untuk menyatakan atau memperkenalkan diriNya kepada manusia yang menjadikan manusia dapat mengenal Allahnya atau mempunyai pengetahuan tentang Allah."14 Dari situlah (pengetahuan tentang Allah) maka muncul istilah "teologi" dari kata "theos," berarti Allah dan "logos," berarti "kata" atau "percakapan". Maka dari itu teologi merupakan "suatu percakapan tentang Allah". ${ }^{15}$ Sekalipun demikian manusia dapat melakukan percakapan dengan Allah, Allah tetap tidak terpahami (Ayub 11:7-dapatkah engkau memahami hakekat Allah, menyelami batas-batas kekuasaan Yang Mahakuasa; Yesaya 40:18). Namun Ia dapat dikenal (Yohanes 14:7; 17:3; dan 1 Yohanes 5:20).

Dari keberadaan atau eksistensi Allah maka muncul beberapa argumentasi seperti argumentasi kosmologikal. Argumentasi ini didasarkan pada hukum sebab-akibat, bahwa setiap sebab harus ada akibatnya. Telah dikatakan di atas bahwa Allah yang misteri itu telah menyatakan diri. Penyataan diri Allah melalui dunia atau alam semesta oleh para teolog disebut sebagai argumentasi kosmologis/logikal. Ini menunjuk pada "alam semesta

\footnotetext{
${ }^{14}$ Harun Hadiwiyono, Iman Kristen (Jakarta : BPK Gunung Mulia, 1992), 29.

15 Paul Enns, The Moody Hand Book of Theology, penerj. Rahmiati Tanudjaja (Malang: Literatur SAAT, 2003), 223.
} 
disekitar kita"16 sebagai suatu "akibat dari sebab yang memadai". ${ }^{17}$ Di dasarkan pada dunia karena secara defakto dunia adalah nyata atau ada secara fisik. Oleh karena dunia ada maka harus ada penyebab tunggal. Hanya saja ketika kita bertanya mengenai penyebab tunggal maka muncul perkembangan atau kemungkinan-kemungkinan. Alam semesta yang sekarang ini ada tentu berada dari yang tidak ada, atau berasal dari sesuatu yang kekal. "Bila berasal dari sesuatu yang kekal, maka sesuatu yang kekal itu bisa alam semesta sendiri yang tentunya harus kekal, atau kebetulan sebagai akibat yang kekal, atau Allah sebagai keberadaan yang kekal". ${ }^{18}$ Logisnya, belum tentu alam semesta menciptakan dirinya sendiri sebab alam semesta tidak ada oleh karena dirinya sendiri. Untuk "menciptakan diri sendiri sesuatu itu harus ada dan tidak boleh ada pada saat yang sama dengan cara yang sama...menciptakan diri sendiri belum pernah diamati dan terjadi secara ilmiah". ${ }^{19}$ Jika alam semesta tidak maka hanya ada satu kemungkinan terakhir yakni Allah. Tetapi apakah Allah merupakan sesuatu akibat dari sebab? Ia bukan produk dari suatu akibat sebab Ia kekal. Maka dari itu akibat mengharuskan adanya sebab. Apabila alam semesta tidak menciptakan dirinya sendiri maka harus ada yang kekal menciptakan atau mengadakan alam semesta ada. Memilih Allah merupakan suatu pilihan yang bersifat teistis berarti satu pribadi yang kekal, berkuasa, hidup dan cerdas telah menyebabkan alam semesta ini ada (Mazmur 19:1-7, ini menunjukkan kontiyuitas tindakan di mana alam semesta menceriterakan kemuliaan dan kebesaran Allah baik siang maupun malam).

Sengaja dimasukkan istilah "cerdas" di atas sebab dari tatanan alam semesta menunjukkan suatu kecerdasan dan kemahageniusan dari satu pribadi yang mengaturnya dalam ketraturan dan menuju satu tujuan. Para teolog

16 Charles, C. Ryrie, Teologi Dasar; Panduan Populer untuk Memahami Kebenaran Alkitab (Yogyakarta : Yayasan Andi, 1991), 39.

17 Ibid.

18 Ibid., 38.

19 Ibid. 
menyebutnya dengan istilah argumentasi "teleologis/logikal". ${ }^{20}$ Mazmur 19:2 menunjukkan bahwa dunia-kosmos merupakan buah pengetahuan Allah atau karya Allah yang. Dari karyaNya dapat dilihat betapa mahageniusnya Allah dalam menciptakan alam semesta bahkan memiliki nilai dan sifat estetis yang luar biasa. Dengan demikian maka manusia yang adalah gambaran Allah (Kejadian 1:26) yang memiliki kecerdasan, moral dan hidup menunjukkan atau mengarahkan kita pada suatu paradigma bahwa yang menciptakan atau yang membentuknya haruslah satu pribadi yang cerdas. Mazmur 94:9 berkta "Dia yang menanamkan telinga ..., Dia yang membentuk telinga ..., dan Dia yang membentuk mata..”. Ini pun berarti Ia adalah pribadi yang cerdas, bermoral dan hidup (argumentasi antropolois/lokal dan moral).

Ia adalah pencipta atau penyebab tunggal adanya dunia. "He is the unmoved mover of the world" dan Ia adalah pribadi yang transenden dan imanent. Ia mencipta dan juga memelihara. Ini menunjukkan betapa sempurnanya Allah itu dan "setiap kesempurnaanNya menguraikan keseluruhan keberadaan-Nya". ${ }^{21}$ Semua sifat yang dimilikinya tidak berdiri sendiri atau terpisah-pisah bahkan sifat yang satu tidak mengungguli sifat-Nya yang lain. Thiessen, Vernon D. Doerksen; Herman Bavink; Millard J. Erickson; Gordon R. Lewis adalah teolog-teolog yang mencoba mengelompokan atributatribut Allah secara kategorial namun satu hal yang perlu diketahui atau dapat saya simpulkan bahwa "semua yang telah diteliti oleh para teolog menunjukkan kesempurnaan Allah di dalam sifat dan tindakanNya terhadap alam semesta dan manusia sebagai gambaran Ilahinya yang ada di dunia dan berada dalam progresive revelation."

Selain sifat-sifatNya yang dikelompokan oleh para teolog maka ada sifat tambahan yang dapat kita lihat, yakni namaNya. Misalnya "elohim" digunakan bagi Allah yang benar. Ada yang mengartikannya sebagai takut. Berarti bahwa

20 Dieter Becker, Pedoman Digmatika-Suatu Kompendium Singkat (Jakarta: BPK Gunung Mulia, 2001), 59.

${ }^{21}$ Charles Ryrie, Teologi Dasar, 47. 
Ia adalah pribadi yang ditakuti, atau dihormati karena memiliki kekuatan. Bahkan dapat dilihat dari nama-nama gabungan, misalnya El-Shaddai artinya Allah yang menyediakan. Namanya sesuai dengan sifatNya sebagai Allah yang menyediakan (Kej. 17:1, 8:3, 35:11; Kel. 6:3).

Melalui penciptaan sebagai wahyu umum, Allah menunjukkan kepada manusia bahwa "Ia mampu, kuat, maha mulia, kudus dan tak tertandingi". Keinginan Allah ini tidak berhenti pada penciptaan melainkan dilanjutkan pada tindakan membangun hubungan. Meskipun hubungan yang di buat pada era edenik (Adam), era Noh terhenti oleh karena sikap manusia namun Allah tidak beralih dan membangun hubungan dengan ciptaan-Nya yang lain melainkan tetap consisten sehingga Ia memunculkan kembali atau mengangkat orang lain sebagai tindakan yang berkesinambungan dari tujuan ilahi-Nya sejak semula dan tetap berjalan menuju puncak dari wahyu progresif. Perjanjian pertama Allah dengan Adam merupakan "basic covenant" untuk keseluruhan dari masa penciptaan hingga inkarnasi Kristus, yang di dalam tulisan Paulus mengenai sejarah dunia, Adam dan Kristus dikaitkan. Di sini Adam menjadi "the head of the old testament and Christ is the head of the new covenant". Oleh Adam, Adam menuntun generasinya ke dalam dosa sedangkan Kristus menuntun generasiNya (dibaca umat-Nya) ke dalam kegenapan perjanjian (Rom. 5:19). Dari waktunya kejatuhan Adam sampai Kristus, Alkitab mencatat enam perjanjian sekunder tambahan. Perjanjian ini adalah pembaruan dan perluasan perjanjian dengan Adam. Masing-Masing menggarisbawahi aspek/pengarah dari tanggung jawab Adam sebagai Gambaran Tuhan. Di (dalam) taman itu, Adam adalah seorang imam dan bertanggung jawab untuk menjaga taman dan Hawa. Ia adalah juga seorang raja, raja yang pertama (Adam is the first king) diberi dominion seluruh dunia. Dan ia adalah seorang nabi untuk Tuhan.

Meskipun demikian, oleh kehendak bebasnya, Adam tidak dapat mengontrol diri dan istrinya atau ia tidak manjalankan tanggungjawabnya sebagai imam, nabi, suami dengan tepat sehingga ia keclongan di mana Hawa jatuh. Tetapi satu hal yang sangat penting dalam peristiwa kejatuhan Adam 
adalah bahwa Allah tidak meninggalkan Adam begitu saja melainkan Allah memulihkan kembali Adam.

Walaupun Adam telah memberontak terhadap Perjanjian Tuhan, Tuhan tetap dengan penuh keindahan mencari orang mewariskan suatu perjanjian baru. Dengan kejatuhan Adam, Adam tidak lagi memiliki hunungan yang akrab. Dari situ Tuhan mencari cara baru, yakni melalui benih perempuan (Kej. 3:15). Benih tersebut kelak akan dikorbankan untuk menghapus "keberdosaan" manusia.

Doktrin perjanjian adalah yang memberi struktur pada sejarah alkitab (kitab-kitab). Seperti yang dikatakan oleh Ralph Smith bahwa hubungan Tuhan dengan Adam adalah convenantal sejak awal. Tetapi Adam memutuskan atau memecahkan perjanjian telah diciptakan. Smith berkata:

The doctrine of the covenant is what gives structure to the Biblical story. God's relationship with man was covenantal from the beginning. But Adam broke the covenant the day he was created. This could have been the end of the story, but God is a God of grace. He renewed His covenant with man and promised to establish a wholly new covenant through a new Adam (Gn. 3:15). The promised Savior would be the Head of a new humanity that would fulfill the purpose of God in creating the world as His kingdom (cf. Rm. 5:12-25) ${ }^{22}$

Sejarah para patriakh menjadi catatan bagi kita bahwa Allah tetap tidak pernah berhenti membangun hubungan dengan manusia sekalipun manusia gagal. von Rad dalam bukunya "The Old Testament Library" mengatakan bahwa "the story of the patriachs the departure from and the re-entry in canaan. Is also the theme of the hexateuch. where the material is massively expanded and throughly permeated theologically".23 Materi mengenai wahyu progresif dibangun kembali dan diperluas namun dalam satu tema.

22 Ralph, A. Smith, The Covenantal Structure of the Bible: Introduction to the Bible. http://www.berith.org/essays/bib/. Diakses 26 Juni 2016

${ }^{23}$ Gerhard von Rad, The Old Testament Library (Philadelphia: Wesminister Pres, 1956), 43. 


\section{Perjanjian Nuh}

Setelah perjanjian Adam (gagal), Allah lalu membuka term baru dengan Nuh. Perjanjian dengan Nuh menandai suatu permulaan baru atau babak baru dalam perjanjian. Seperti halnya dalam perjanjian Adamik, di mana Allah menjadi penentu atau pembuat perjanjian demikian juga dalam Noahik covenant. Smith berpendapat bahwa "Nuh dihormati sebagai Adam baru--- Noah is regarded as a new Adam" dan Tuhan memberkati Nuh dan para putra nya, and God said unto Noah "...Be fruitful, and multiply, and replenish the earthGenesis 9:1-KJV". Allah memulai ucapan-Nya dengan berkat, seperti dalam Kejadian 9:1, "and God blessed Noah and his sons". Allah mengulang pernyataan ini seperti sediakala ketika Ia mengucapkannya kepada Adam "And God blessed them, and God said unto them, Be fruitful, and multiply, and replenish the earth, and subdue it: and have dominion over the fish of the sea, and over the fowl of the air, and over every living thing that moveth upon the earth-1:28-KJV". Artinya bahwa "berkat yang diterima Nuh sama dengan berkat yang diterima Adam (Tuhan tidak punya anak emas/gold of son)". Kini Allah menunjuk Nuh sebagai penerus "Adamik covenan" atau Allah merekonstruksi perjanjian Adamik dengan menunggangbalikan Sodom dan Gomora. Setelah peristiwa penghukuman Sodom dan Gomora (tanda penghancuran dan pemutusan perjanjian yang lama), kini tinggal keluarga Nuh yang ada di atas bumi pada masa itu. Ini merupakan perluasan dari perjanjian Edenik.

Nuh setelah kejadian itu, ia hidup dalam dunia yang baru (new world), dan era yang naru (new era). Era dan dunia yang lama telah dihancurkan. Ini merupakan sejarah baru dalam pergerakan dan perkembangan hidup umat manusia. Allah memulai masa yang baru ini dengan empat keluarga. Namun dalam perjanjian dengan Nuh, tidak terdapat gagasan baru. Memang perjanjian dengan Nuh disebut perjanjian. Tetapi tidak ada gagasan atau term yang baru. Melainkan merupakan kelanjutan dari term atau gagasan yang sama dalam 
perjanjian Edenik. Nuh sekalipun hidup dalam dunia yang baru namun tetap membawa dosa warisan dan konsep penebusan tetap ada. Mari kita melihat paling tidak ada kesamaan konsep dalam kedua perjanjian ini (Adam/eden dan Nuh). Konsep manusia sebagai nabi, imam, dan raja sama dengan konsep awal. Di mana Nuh dengan jelas menerima otoritas tersebut. Ia berfungsi sebagai imam di (dalam) menawarkan pengorbanan (Kej. 8:20) dan sebagai nabi di dalam mengucapkan berkat dan kutuk pada (atas) para putranya (Kej. 9:25). Tetapi perbedaan yang utama di dalam otoritas manusia adalah hal tentang pengadilan. Sebelum air bah otoritas manusia tentang pengadilan telah terbatas pada kasus selain dari hukuman mati (Kej. 4:14-15). Tetapi Perjanjian Nuh dengan datang sebagai otoritas untuk melaksanakan eksekusi bagi para pembunuh (Kej. 9:6). Ini bukanlah semata-mata Tuhan melegalkan atau memberi perintah untuk melakukan pembunuhan. Melainkan harus di lihat dalam konteks dan konsep seperti ketika Tuhan menghukum Sodom dan Gomora. Tuhan sendiri yang mengeksekusi mereka (Kej. 6:11-13), Ia memerintahkan Nuh untuk melaksanakannya. Nah, dalam hal ini "Nuh menjadi pengantara perjanjian Allah bagi semua umat manusia. Hal ini juga merupakan perjanjian yang tidak bersyarat sebagaimana tidak ada juga persyaratan yang dikenakan pada perjanjian itu. Allah mengindikasikannya sebagai sesuatu yang akan Ia lakukan (Kej. 6:18; 9:9,11)". ${ }^{24}$

Di antara kedua perjanjian ini (Eden dan Nuh) memang terdapat kesaman sehingga ada beberapa ahli teologi (teolog) mengatakan bahwa perjanjian edenik sama dengan perjanjian Noahik. Sebab masih dalam nafas teologi penciptaan. Selanjutnya, Allah membuat perjanjian yang tak bersyarat (unconditional) dengan Abraham. Namun hal ini akan dibahas pada bagian berikutnya. 


\section{Perjanjian Abraham}

Sehubungan dengan keberdosaan umat manusia yang sudah terjadi, Allah sekarang bertindak untuk memberkati dan menebus umat manusia yang telah jatuh dengan melakukannya melalui bangsa tertentu. Abraham menjadi pusat figur di mana melaluinya Allah bertindak. "Ia menjanjikan suatu berkat bagi Abraham dan keturunannya yang akan melahirkan seorang Mesias dengan berkat bagi orang Ibrani dan bangsa-bangsa di dunia dalam kerajaan milenial". ${ }^{25}$

Setelah penghakiman, dengan penuh kasih karunia memperbaharui perjanjian-Nya dengan manusia sehigga Ia memenuhi janji keselamatan dan membangun kembali kerajaan yang telah dirusak oleh iblis dengan menggoda Adam untuk memberontak. Untuk tujuan tersebut, yakni mendirikan atau memperbaharui janji penyelamatan, Allah memilih Abraham di mana benih ilahi akan muncul dari keturunan Abraham.

Dalam konsep pemilihan Abraham sebagai jalan menuju penggenapan perjanjian penebusan, maka orang harus mendekati Tuhan melalui Abraham. Artinya keselamatan datang dari bangsa Yahudi yang secara kolektif melalui Abraham. Perjanjian penebusan kali ini berbeda dari yang sebelumnya. Di sini Abraham diberi visi di mana Tuhan akan menebus dosa dunia dan dipulihkan untuk Tuhan. Tuhan berkata "melalui keturunanmu semua kaum di muka bumi memperoleh berkat (Kej. 12:3b; 18:18; 26:4; dan 28:14). Prospek dari berkat universal ini adalah merupakan karakteristik dari periode nubuatan. Di sini juga Abraham bisa dilihat sebagai imam dan juga raja. Karena itu, ia menawarkan pengorbanan, memimpin suatu angkatan perang (Kej. 22:3; 14:13; 17:5-6). Lebih dari itu, Abraham merupakan orang pertama dalam alkitab yang dipanggil nabi (Kej. 20:7). Saya kira, berkat Abraham yang dijanjikan Allah kepadanya mulai dirasakan oleh bangsa lain ketika Yusuf berada di Mesir. Kita tahu tentang kelaparan yang melanda Mesir kala itu, namun oleh karena kasih 
karunia Tuhan yang dikaruniakan Tuhan melalui kebijaksanaan Yusuf sehingga Yusuf dapat memahani makna dari mimpi tersebut. Maka dari itu Yusuf dengan bijaksana mempersiapkan segala sesuatu sehingga bangsa Mesir dan juga termasuk bangsa dari orang tuanya (Yakub) mendapat berkat.

Dalam bukunya Paul Enns, Enns melihat perejanjian Abraham sebagai perjanjian yang tertinggi. Ini memang benar sebab setelah dua kali Allah membuat perjanjan dengan manusia (Adam dan Nuh), manusia gagal. Namun yang menjadi catatan bagi kita adalah bahwa sekalipun Allah menggati orang atau pelaku atau pembawa amanat perjanjian satu hal yang tidak berubah adalah "konsep atau termnya tetap sama". Konsep ini berjalan menuju puncak daripada progresive revelation. Setelah babak Edenik dan Noahik berakhir dengan Allah memanggil Abraham. Pemanggilan Abraham bukan untuk memenuhi janji "pengembangbiakan kehidupan umat manusia" seperti Edenik dan Noahik. Dua tokoh di babak pertama-Edenik dan Noahik, membawa berkat tersendiri melalui firman yang diucapkan Tuhan kepada mereka "beranak cuculah dan bertambah banyak; penuhilah bumi (Kej. 1:28)”. Dan “... beranak cuculah dan bertambah banyaklah serta penuhilah bumi (Kej. 9:1)". Maka dari itu, berkat yang dibawa oleh Adam dan Nuh berbeda tetapi tetap dalam satu tema yaitu "perjanjian" di mana perjanjian ini berjalan menuju progresive revelation.

Di pasal 12 dari kitab Kejadian, Allah memanggil Abraham untuk membawa berkat kepada bangsa-bangsa lain dengan berkata "pergilah dari ...(ayat 1). Aku akan membuat engkau..., Aku akan memberkati engkau..., dan engkau akan menjadi berkat (ayat 2). ...dan olehmu semua kaum di muka bumi akan mendapat berkat (ayat 3).

Langkah pertama dalam perjanjian Tuhan dengan Abraham di awali dari pemanggilan Abraham. Yahweh berkata "I am yahweh who brought thee out from Ur of the Chaldees, to give thee this land, and that thou mightest possess it- 
15:7".26 Dalam pemanggilan Abraham ini, telah termaktub tiga perjanjian, yakni:

- Tanah Perjanjian (promis of land-Kej. 12:1). Allah memanggil abraham keluar dari tanah Ur Kasdim ke tanah yang akan menjadi milik keturunannya kelak. Menurut Paul Enns, “...janji itu dikonfirmasikan dengan suatu kovenan kasut; dimensi kovenan itu diberikan di Kejadian 15:18-21...Aspek tanah perjanjian dalam kovenan Abraham lebih jauh dijelaskan lagi di Ulangan 30:1-10, yang adalah kovenan Palestina”. ${ }^{27}$

- Perjanjian Keturunan (Kej.12:2). Allah menjanjikan kepada Abraham bahwa melaluinya Allah akan membuatnya menjadi bangsa yang besar. "Janji ini (dijelaskan lebih jauh di kovenan Daud di 2 Sam. 7:12-16) akan terjadi pada garis keturunan kerajaan Daud di mana kerajaan Mesias akan memerintah atas bangsa Ibrani”. ${ }^{28}$

- Perjanjian Berkat dan Penebusan (Kej. 12:3). Di ayat 3, Allah kembali menjanjikan kepada Abraham bahwa melaluinya (keturunannya) semua kaum di muka bumi akan memperoleh berkat. Berkat ini meliputi berkat rohani dan penebusan.

Dalam dua perjanjian pasca kejatuhan, visi penebusan masih kabur. Baru di perjanjian berikutnya (perjanjian Abraham) perjanjian yang baru ini diperluas dan visi penebusan diperjelas. Sekalipun kenyataannya seperti itu bahwa visi penebusan masih kabur tetapi dasarnya telah diletakan terutama di perjanjian Nuh. Allah dalam kemahatahuan-Nya mengerti bahwa Nuh hidup benar. Oleh karena itu Allah mengambil tindakan penyelamatan terhadap keluarga yang benar dan menghacurkan yang lain "yang tidak benar". Artinya perjanjian penebusan menjadi fondasi yang tersembunyi (the hidden fondation of the salvation of covenant). Namun demikian perjanjian Abraham menjadi acuan atau rujukkan dari perjanjian di era perjanjian lama. Baik perjanjian Musa, Daud dan maupun perjanjian baru semuanya didasarkan pada perjanjian

\footnotetext{
26 Ibid., 63.

27 Paul Enns, The Moody Hand Book, 58.

28 Ibid.
} 
Abrahamik. Ralph Smith juga berpendapat yang sama bahwa, "thus the Abrahamic covenant became the "reference covenant" for the rest of the covenants in the old covenant era. The Mosaic, the Davidic, and the Restoration covenants are all explicitly grounded in the Abrahamic covenant". 29 Perjanjian baru juga menjadi point penting dalam perjanjian Abraham.

Di atas telah dijelaskan mengenai perjanjian tertinggi di mana perjanjian Abraham menjadi perjanjian yang tertinggi hanya itu bukan puncak. Puncak wahyu progresif bukan di perjanjian Abraham melainkan itu merupakan jalan yang dilewati untuk sampai pada puncak dari wahyu progresif yaitu janji penebusan (redamption of covenant). Tokoh yang menjadi pusat dari janji penebusan atau yang berada di puncak wahyu progresif bukan Abraham, bukan Musa dan bukan Daud melainkan keturunan Abraham dan Daud, yakni Kristus.

Perjanjian penebusan adalah merupakan perjanjian biblikal yang ketiga (pertama, perjanjian Eden dan Nuh, sama. Kedua, perjanjian Abraham: TanahPalestina, Daud, dan Perjanjian tentang kitab Injil besar yang ketiga adalah perjanjian penebusan. Maka di atas perjanjian penebusan ini, misi dilaksanakan agar semua orang mengalami penebusan Allah.

${ }^{29}$ Ralph Allan Smith, The Covenantal Structure of the Bible: Introduction to the Bible. http://www.berith.org/essays/bib/. Diakes 26 Juni 2016 


\section{BAB DUA}

\section{AMANAT AGUNG DAN MISI GEREJA}

\section{A. Amanat Agung sebagai Fondasi Misi Gereja (Mat. 28:16-20)}

Misi dan penginjilan selalu berkaitan dengan perintah untuk pergi. Amanat Agung harus dilihat sebagai perintah Agung misi dan penginjilan. "Titik berangkat misi-penginjilan adalah pada pergi, memenangkan, dan memuridkan"30.

Menurut ayat 16, kesebelas muridlah yang menjadi pendengar asli dari perintah itu. Para rasul lebih dari individu yang ingin secara pribadi mematuhi ajaran-ajaran Kristus. Orang-orang ini berdiri sebagai pendiri dan pemimpin Gereja yang akan ditegakkan dan dilipatgandakan melalui kesaksian mereka dan kuasa Roh Kudus. Dipahami bahwa setiap anggota gereja akan diajar untuk mematuhi segala sesuatu yang diperintahkan Tuhan, termasuk perintah untuk memuridkan semua bangsa.

Asumsinya adalah, bahwa pesan-pesan tentang bangsa-bangsa secara khusus merupakan bagian dari jemaat: pria dan wanita yang sudah cenderung memikirkan atau berinteraksi dengan apa yang terjadi di seluruh dunia. Ini akan masuk akal jika (a) kedekatan dengan orang-orang dan budaya adalah motivasi utama untuk menjangkau bangsa-bangsa dengan Injil; dan (b) satusatunya cara kepatuhan terhadap perintah Kristus adalah benar-benar meninggalkan rumah dan tinggal di tempat lain demi Injil.

${ }^{30}$ Bandingkan dengan, Yakub Tomatala, Penginjilan Masa Kini. Jilid 2 (Malang: Gandum Mas, 1998), 10-24. Stephen Tong, Teologi Penginjilan (Surabaya: Momentum, 2007), 7-10. Stephen Tong memberikan penekanan pada, orang yang mengetahui teologi tidak mungkin tidak menginjil sebaliknya orang yang menginjil tidak mungkin tidak belajar teologi. Dalam kaintanya dengan misi-penginjilan, orang yang dimenangkan dimuridkan sehingga yang dimuridkan diharapkan dapat memenangkan orang lain dan mengajar mereka mengenal Kristus. 
Tujuan dari misi bukanlah hanya menginjili semua orang, tetapi juga untuk memuridkan yang mematuhi semua yang diperintahkan Kristus. Hal pertama dapat dicapai dengan cepat melalui individu, sedangkan yang kedua membutuhkan waktu dan membutuhkan komunitas. Karena itu, memenuhi Amanat Agung mengharuskan penanaman gereja.

Matius 28:18-20, dikenal sebagai ayat yang menyatakan mengenai Amanat Agung. Oleh karena itu, untuk membicarakan perihal Amanat Agung, maka sangatlah penting dijabarkan dan diuraikan secara terperinci apa yang sesungguhnya dimaksudkan dalam ayat tersebut.

Ayat 19-20, 'Jadikanlah semua bangsa murid-Ku'. Dalam bahasa Yunaninya, 'jadikan murid' adalah satu-satunya kata perintah dalam bagian ini. Sedangkan kata-kata 'pergilah', 'baptislah', dan 'ajarlah' merupakan participles (kalau diterjemahkan ke bahasa Inggris menjadi 'kata kerja + ing', yaitu: going, baptizing, teaching). Ini menunjukkan bahwa penekanan utama dari bagian ini adalah 'menjadikan murid Yesus'. Sedangkan 'pergi', 'membaptis' dan 'mengajar' adalah hal-hal yang harus dilakukan untuk bisa menjadi murid.

Berbeda dengan Matius 10:5-6, di mana sasaran penginjilannya hanyalah orang-orang Yahudi, maka sekarang sasarannya adalah 'semua bangsa'! Dalam penulisan teks aslinya, kata bangsa adalah etne (yunani), yang mana mengandung makna "suku bangsa". Karena itu jelas tidak benar kalau dikatakan:

- Kristen adalah agama untuk orang Yahudi saja.

- Kristus adalah Juruselamat untuk orang Yahudi saja.

Hal ini secara implisit menunjukkan bahwa Yesus Kristus adalah satusatunya jalan ke surga, karena kalau tidak mengapa Yesus menyuruh menjadikan semua bangsa (suku bangsa) murid-Nya? Ajaran bahwa Kristus adalah satu-satunya jalan ke surga harus diterima dan dipertahankan, karena Kitab Suci mengajar demikian (Yoh. 14:6 Kis 4:12; 1 Yoh. 5:11-12). "Kata Yesus kepadanya: 'Akulah jalan dan kebenaran dan hidup. Tidak ada seorangpun yang 
datang kepada Bapa, kalau tidak melalui Aku"' (Yoh. 14:6). Ayat ini hanya mempunyai 3 kemungkinan: Kitab Sucinya salah; Yesus tidak pernah mengatakan pernyataan ini, tetapi Kitab Suci mencatat seolah-olah Yesus mengatakan pernyataan ini; Kitab Sucinya betul; Yesus memang pernah mengucapkan pernyataan ini. Tetapi Yesusnya berdusta, karena Ia menyatakan diri sebagai satu-satunya jalan kepada Bapa padahal sebetulnya tidak demikian; Kitab Sucinya betul, dan Yesusnya tidak berdusta, sehingga Ia memang adalah satu-satunya jalan kepada Bapa / ke surga.

Dari ketiga kemungkinan ini, jika yang pertama atau yang kedua, itu benar, maka sia-sialah kepercayaan orang Kristen. Karena apa gunanya menjadi Kristen tetapi mempercayai Kitab Suci yang salah, atau mempercayai Tuhan pendusta! Kisah Para Rasul 4:12, "Dan keselamatan tidak ada di dalam siapapun juga selain di dalam Dia, sebab di bawah kolong langit ini tidak ada nama lain yang diberikan kepada manusia yang olehnya kita dapat diselamatkan”. 1 Yohanes 5:11-12, "Dan inilah kesaksian itu: Allah telah mengaruniakan hidup yang kekal kepada kita dan hidup itu ada di dalam Anak-Nya. Barangsiapa memiliki Anak, ia memiliki hidup; barangsiapa tidak memiliki Anak, ia tidak memiliki hidup". 1Timotius 2:5, "Karena Allah itu esa dan esa pula Dia yang menjadi pengantara antara Allah dan manusia, yaitu manusia Kristus Yesus”.

Hanya orang sesat yang tidak menghargai otoritas Kitab Suci dan yang ingin memutarbalikkan Kitab Suci yang bisa menafsirkan bahwa ayat-ayat ini tidak menunjukkan Yesus sebagai satu-satunya jalan ke surga. Perhatikan bahwa Kisah Para Rasul 4:12 menyatakan bahwa 'keselamatan itu ada di dalam Yesus', dan 1Yohanes 5:11-12 menyatakan bahwa 'hidup yang kekal itu ada di dalam Yesus'. Bayangkan, Yesus sebagai sebuah kotak yang di dalamnya berisikan keselamatan/hidup kekal. Kalau seseorang menerima kotaknya (Yesus), maka ia menerima isinya (keselamatan / hidup yang kekal), dan sebaliknya kalau ia menolak kotaknya (Yesus), otomatis ia juga menolak isinya (keselamatan / hidup yang kekal).

Perhatikan juga pernyataan, 'di bawah kolong langit ini' dalam Kisah Para Rasul 4:12, dan 'barangsiapa tidak memiliki Anak' dalam 1 Yohanes 
5:12. Ini menunjukkan bahwa tidak mungkin pernyataan ini ditujukan hanya untuk orang-orang yang telah mengenal Kristus. Ayat-ayat tersebut di atas berlaku untuk seluruh dunia! Juga perhatikan, bahwa berbeda dengan Yohanes 14:6 yang diucapkan oleh Yesus kepada murid-murid-Nya (orang-orang yang percaya), maka Kisah Para Rasul 4:12 diucapkan oleh Petrus kepada orangorang Yahudi yang anti Kristen! Jadi jelas bahwa ayat ini tidak mungkin dimaksudkan hanya bagi orang yang sudah mengenal Kristus! Karena itu, hal ini menunjukkan bahwa orang yang tidak percaya Yesus pasti masuk neraka, ini bukan menghakimi, tetapi percaya pada kebenaran Kitab Suci!

Orang-orang yang berkata bahwa mereka tidak tahu akan nasib orang yang tidak percaya Yesus (dengan alasan bahwa manusia tidak maha tahu; hanya Allah yang maha tahu) adalah orang yang tidak menghargai otoritas Kitab Suci! Mereka bukannya tidak tahu, tetapi memang tidak mau tahu! Perlu berhati-hati dengan orang yang mengatakan 'moga-moga Tuhan menyediakan jalan untuk selamat bagi orang yang mati tanpa Kristus'. Kata-kata seperti ini tampaknya penuh kasih, tetapi jelas merupakan kata-kata dari orang yang tidak percaya pada Firman Tuhan! Mengatakan 'moga-moga orang di luar Kristus bisa selamat' adalah sama dengan mengatakan 'moga-moga kata-kata Yesus dalam Yohanes 14:6 itu adalah salah atau dusta! Karena Kristus adalah Allah sendiri dan Ia satu dengan Bapa-Nya (Yoh. 10:30). Karena itu sikap kepada Yesus Kristus merupakan sikap terhadap Allah Bapa (Yoh. 5:23, 14:9, 15:23, 1 Yoh. 2:22-23).

Dengan demikian, orang yang tidak percaya kepada Yesus, sama dengan tidak percaya kepada Allah. Lalu bagaimana ia mau masuk surga yang adalah milik Allah? Karena Kristus adalah satu-satunya Penebus atau Juruselamat. Orang yang tidak mau percaya dan menerima Yesus sebagai Juruselamat, harus membayar dosanya sendiri, dan karena itu ia harus masuk ke neraka selamalamanya!

Pergilah. Untuk bisa pergi mencari jiwa, maka orang yang hendak diutus sudah lebih dahulu datang kepada Kristus! Bandingkan, Matius 4:19 yang mengatakan: "Mari, ikutlah Aku, dan kamu akan Kujadikan penjala 
manusia”. Jadi, harus ikut Yesus duhulu dan setelah itu menjadi penjala manusia! Kata 'pergi' jelas menunjukkan bahwa orang percaya tidak boleh hanya menunggu sampai orang luar datang ke gereja. Ia harus pergi ke luar mencari mereka yang "terhilang"!

Baptislah mereka dalam nama Bapa, Anak dan Roh Kudus. Kata 'nama' ada dalam bentuk singular (tunggal), sekalipun di belakangnya ada 3 pribadi, yaitu Bapa, Anak dan Roh Kudus. Ini salah satu dasar dari doktrin Allah Tritunggal. Perlu disadari bahwa sekalipun istilah 'Tritunggal' itu memang tidak ada dalam Kitab Suci, tetapi konsep tentang Tritunggal jelas ada dalam Kitab Suci. Ini adalah satu-satunya formula baptisan dalam Kitab Suci, dan karena itu maka pada waktu Pendeta melakukan baptisan, maka ia mengucapkan kata-kata 'Aku membaptis kamu dalam nama Bapa, Anak dan Roh Kudus'.

Pada abad ke-20 ini, ada banyak gereja dan hamba Tuhan yang menambahi formula baptisan itu menjadi 'Aku membaptis kamu dalam nama Bapa, Anak dan Roh Kudus, yaitu Tuhan Yesus Kristus'. Ini mungkin dilandasi oleh ayat-ayat seperti Kisah Para Rasul 2:38; 8:16; 10:48; 19:5 (baptisan dalam nama Tuhan Yesus).

Tetapi perlu disadari bahwa:

- Kata-kata itu salah secara teologis, karena 'Bapa, Anak dan Roh Kudus' tidak sama dengan 'Tuhan Yesus Kristus'.

- Ayat-ayat ini (Kis. $2: 38 ; 8: 16 ; 10: 48 ; 19: 5$ ) tidak menunjukkan formula baptisan! Kata-kata 'dibaptis dalam nama Tuhan Yesus' hanya menunjukkan bahwa orang-orang itu dibaptis atas otoritas Tuhan Yesus, atau bahwa orang-orang itu di baptis masuk ke dalam tubuh Kristus.

- Mengapa dalam Amanat Agung, kata 'baptis' mendahului kata 'ajar'? Ada yang menganggap bahwa ini adalah dasar dari baptisan bayi, karena untuk bayi memang baptisan mendahului pengajaran! Ada juga yang mengatakan bahwa ini disebabkan karena baptisan hanya dilakukan satu kali sedangkan pengajaran dilakukan seumur hidup. 
'Ajarlah mereka melakukan segala sesuatu yang telah Kuperintahkan kepadamu'. Kata 'segala sesuatu' menunjukkan bahwa hamba Tuhan harus mau dan berusaha untuk mengajarkan seluruh Firman Tuhan, bukan hanya sebagian-sebagian (yang gampang, yang praktis-praktis saja, atau yang disenangi jemaat dsb). Tetapi kalau hamba Tuhan harus mengajarkan seluruh Firman Tuhan, maka jelas bahwa jemaat harus mau belajar seluruh Firman Tuhan! Kata 'melakukan' menunjukkan bahwa hamba Tuhan harus mengajar dengan tujuan supaya ajaran itu ditaati, dan jemaat harus belajar dengan tujuan mentaati Firman Tuhan!

Jadi apa yang menjadi tujuan belajar Firman Tuhan? Bukanlah hanya untuk menambah pengetahuan teologis atau "mengisi otak", supaya menang dalam berdebat, tetapi supaya bisa hidup sesuai dengan kehendak Tuhan melalui pelajaran Firman Tuhan.

Ayat 20b. Janji penyertaan Tuhan Yesus. Perintah untuk memberitakan Injil dalam ayat 19-20a memang berat, tetapi Tuhan berjanji untuk menyertai orang yang mau mentaati perintah itu! Dalam memberitakan Injil, harus disadari bahwa akan ada serangan setan bagi mereka yang memberitakan Injil. Tetapi jangan takut, karena Tuhan Yesus berjanji untuk menyertai senantiasa!

\section{B. Amanat Agung dalam Kisah Para Rasul}

Selain dalam Injil Matius 28: 18-20, untuk memberikan gambaran yang lengkap mengenai Amanat Agung Tuhan Yesus, harus dibaca juga ayat-ayat lain yang berkaitan dengan perihal tersebut, yaitu antara lain: Markus 16: 1418; Lukas 24: 46-49; Yohanes 20: 21-23; Kisah Para Rasul 1:8. Ayat-ayat tersebut menceritakan tentang bagaimana Kristus memerintahkan muridmurid-Nya untuk memberitakan dan mengajarkan Injil ke seluruh dunia (bangsa dan segala makhluk). Tuhan Yesus memerintahkan mereka untuk menjadikan segala bangsa murid-Nya, membaptiskan orang yang percaya, dan memberitakan Injil dengan disertai tanda-tanda ajaib. Jika ingin melihat 
bagaimana para murid tersebut mengimpartasikan Amanat Agung, maka Kisah Para Rasul menjadi rujukkan.

Mengerti apa yang dimaksudkan Yesus dengan memberitakan Injil, mengajarkan pertobatan, dan pengampunan dosa di dalam Nama-Nya, maka dapat dilihat dan dipelajari dari khotbah-khotbah yang ada dalam Kisah Para Rasul. Banyak hal yang dapat dipelajari dan diketahui melalui Kitab Kisah Para Rasul, di antaranya: tentang tanda-tanda ajaib yang mengikuti orang percaya; tentang bagaimana berbicara dengan bahasa Roh; menyembuhkan orang sakit; mengusir setan; dan memegang ular dan kalajengking. Amanat itu belum berubah. Arti dari penggenapannya dan mentaatinya adalah sama. Interpretasi sebagaimana dilihat di dalam Kisah Para Rasul dan Surat-surat Rasul adalah sama. Orang-orang yang belum percaya dapat memperdebatkan perihal "berkata-kata dalam bahasa Roh, menyembuhkan, mengusir setan-setan", dan juga dapat memperdebatkan mengenai cara baptisan air. Kisah Para Rasul menjadi jawaban terhadap apa yang Yesus maksudkan dalam perintah Amanat Agung sebagaimana tercatat di dalam Injil. Baik Injil maupun kitab Kisah Para Rasul harus selaras (memang sudah selaras). Yang satu tidak bisa menentang yang lainnya. Kitab Injil adalah "perintah" dari Yesus, dan kitab Kisah Para Rasul adalah "penggenapan" terhadap perintah-perintah itu. Kitab Injil mengatakan apa yang Kitab Kisah Para Rasul maksudkan, dan mengartikan apa yang Ia katakan. Dengan demikian apa yang dikatakan dan dilakukan seperti yang dicatat dalam Kisah Para Rasul adalah representasi dari Amanat Agung tersebut. Oleh karena itu pernyataan berkaitan dengan misi seperti yang dinyatakan dalam Kisah Para Rasul dapat menjadi acuan dalam pelaksanaan Amanat Agung pada Gereja Misioner masa kini. Gereja tidak boleh melalaikan Amanat Agung. Melakukan mandat dari Amanat Agung merupakan tugas mutlak bagi gereja, hingga Injil tersebar sampai ke seluruh dunia. Karena hal ini sesuai dengan Matius 24:14, "Dan Injil Kerajaan ini akan diberitakan di seluruh dunia menjadi kesaksian bagi semua bangsa, sesudah itu barulah tiba kesudahannya." 
Dalam Kisah Para Rasul 1:8, dikatakan bahwa "Tetapi kamu akan menerima kuasa, kalau Roh Kudus turun ke atas kamu, dan kamu akan menjadi saksi-Ku di Yerusalem dan di seluruh Yudea dan Samaria dan sampai ke ujung bumi.". Kata Yunani untuk "kuasa" dalam Kisah Para Rasul 1:8 adalah "Dunamis", artinya "Kekuatan, Kemampuan" (dinamit). Dengan demikian yang dimaksud "kuasa" dalam ayat tersebut adalah "Kamu akan menerima kemampuan/ kekuatan (Kuasa) setelah Roh Kudus turun ke atasmu”.

Otoritas adalah milik Allah yang diejawentahkan melalui gereja. Gereja hanya sebagai alat terwujudnya misi Allah. Maka setiap pasal dalam Kisah Para Rasul yang menceriterakan tentang pelayanan misi adalah demonstrasi merupakan manifestasi kuasa Roh Kudus, bukan kemampuan manusia. Ia mampu melakukan segala hal karena Ia adalah Allah. Roh Kudus adalah setara dalam keagungan, kuasa, kemuliaan, kehormatan Allah Bapa dan Allah Anak. Sedangkan kata Yunani martures dalam Kisah Para Rasul 1:8 berarti "menjadi saksi, menyaksikan".

Berpijak dari Kisah Para Rasul 1:8 inilah, Gereja Mula-mula mulai pergi menjadi saksi dan memberitakan Injil. Bukti kemisioneran Gereja Mula-mula di mulai dari Yerusalem (Kis. 1:8; 1:4; Luk. 24:47), Yudea (Kis. 2:9, 14; 8:1, 40; 9:31-43; Pasal 10-11), Samaria (Kis. 8 s/d 10), dan Ujung bumi (Kis. 11:19-26; Pasal 13 s/d 28).

Pada awalnya, Gereja Mula-mula hanya memfokuskan penginjilannya di Yerusalem saja, tetapi penganiayaan terhadap Gereja Mula-mula, membuat jemaat di Yerusalem tersebar ke seluruh Yudea dan Samaria (Kis. 8:1). Peristiwa inilah yang menjadikan Injil diberitakan ke daerah-daerah di luar Yerusalem (Kis. 8:4). Perhatikan, pasal 8 dimulai dengan akibat pembunuhan Stefanus, yaitu penganiayaan yang hebat terhadap gereja Tuhan yang mulamula itu. Kemudian pasal 8 menceritakan beberapa peristiwa dalam riwayat seorang teman sekerja Stefanus. Stefanus dan Filipus dipilih dan dilantik menjadi diaken (pasal 6). Stefanus bersaksi, dan mati syahid (pasal 7). Pada fasal 8, kita menyaksikan pengalaman keberanian Filipus bersaksi. 
Injil juga mulai diberitakan kepada orang-orang non-Yahudi (Kis. 10, 11), walaupun hal ini sempat menjadi sebuah pertentangan besar, namun akhirnya mereka menyadari bahwa adalah kehendak Tuhan untuk Injil juga diberitakan kepada orang-orang non-Yahudi, Injil harus diberitakan ke seluruh dunia. Sidang Yerusalem (Kis. pasal 12) menjadi sebuah titik tolak bagi kemisioneran Gereja Mula-mula untuk bersaksi dan memberitakan Injil ke seluruh dunia (termasuk orang-orang non-Yahudi).

Setelah mereka bersidang, mereka mengutus utusan-utusan resmi untuk membawa dan mengantarkan surat hasil sidang tersebut kepada jemaat di Antiokhia (Kis. 12:22-29). Jemaat di Antiokhia itu tentu bergembira sekali mendengar keputusan sidang itu. Pelayanan rohani yang mereka jalankan itu dibenarkan oleh seluruh gereja Tuhan. Kini mereka bersedia menjangkau terus ke daerah-daerah yang jauh.” Gereja Mula-mula sangat bersemangat dan bahkan berorientasi dalam tugas pemberitaan Injil. Injil diberitakan dan tersebar sampai ke seluruh dunia (hingga sekarang).

\section{Misi dan Tanggung Jawab Gereja}

Kata Misi (Mission) berasal dari bahasa Latin "missio", berkaitan dengan kata "missum", yang berarti "to send" (mengirim/ mengutus). Istilah ini menekankan mengirim dengan otoritas. Dalam hal ini, yang dikirim atau diutus diperlengkapi dengan otoritas dari yang mengirim untuk tujuan khusus yang akan dicapai. Tekanan penting dari "misi atau pengutusan Allah" berbicara tentang Allah sebagai pengutus, di mana Allah adalah sumber, inisiator, dinamisator, pelaksana, dan penggenap misi-Nya.

Allah adalah Allah yang memiliki misi. Misi pasti berbicara tentang pengutusan dan misi juga berarti "that God is a 'sending' God"31. Dalam konteks God is a sending God, maka kita dapat memahami bahwa Allah Bapa mengutus Putera-Nya sebagai "misionaris" dari sorga, sebab Allah "yang menghendaki

${ }^{31}$ Craig van Gelder dan Dwight J. Zscheile, The Mission Church in Perspective: Mapping Trends and Shapping the Conversation (USA: Baker Academi, 2017), 3. 
semua orang diselamatkan dan memperoleh pengetahuan tentang kebenaran" (I Timotius 2:4). Yesus memberikan Amanat Agung kepada murid-murid-Nya: Karena itu pergilah, jadikanlah semua bangsa murid-Ku dan baptislah mereka dalam nama Bapa dan Anak dan Roh Kudus (Mat. 28:19). Dalam Markus 16:15, Yesus berbicara tentang penginjilan dunia, "Engkau, pergilah ke seluruh dunia, beritakanlah Injil kepada segala makhluk." Mengenai penginjilan dunia, Lukas 24:47 mengatakan, “... dan lagi: dalam nama-Nya berita tentang pertobatan dan pengampunan dosa harus disampaikan kepada segala bangsa, mulai dari Yerusalem." Sedangkan dalam Yohanes 20:21, Yesus berbicara tentang penginjilan dunia, "Seperti Bapa mengutus Aku, juga sekarang Aku mengutus kamu." Sebelum Yesus naik ke surga, Kisah Para Rasul 1:8 mencatat bahwa, "Kamu akan menerima kuasa, kalau Roh Kudus turun ke atas kamu, dan kamu akan menjadi saksi-Ku di Yerusalem dan di seluruh Yudea dan Samaria, dan sampai ke ujung bumi." "Kedangan Kristus ke dunia juga dapat dilihat sebagai "aksi misi Allah dalam sejarah manusia" 2 .

Misi merupakan keinginan terdalam dari hati Allah untuk menyelamatkan manusia yang berdosa. Misi memancar dari hati Tuhan melalui penginjilan dan pemuridan, yang bertujuan memimpin orang lain kepada Allah, menjadi murid yang bersaksi, mencari yang terhilang (membawa dunia yang terhilang), memelihara (misi pemeliharaan-memberi makan) sehingga menjadi tubuh Kristus yang bertanggung jawab.

Gereja adalah tanda dan alat kerajaan Allah, suatu umat yang dipersatukan oleh iman dalam proklamasi Injil tentang Yesus sebagai Allah yang disalibkan dan bangkit. Misi gereja adalah untuk pergi ke dunia dalam kuasa Roh Kudus dan memuridkan dengan memberitakan Injil, memanggil orang-orang untuk menanggapi Injil dan mengalami pertobatan, hidup dalam kebenaran dan menunjukkan kebenaran dengan hidup di bawah kekuasaan Tuhan.

32 Ibid., 3. 
Misi gereja adalah untuk mengenal Yesus Kristus dan menghasilkan buah Roh-Nya. Kita hanya benar-benar mencintai dengan kasih "agape", ketika kita pertama kali memahami bagaimana Dia menunjukkan kasih-Nya kepada kitadengan mengampuni semua dosa kita; membebaskan kita dari standar hukum yang mustahil kita penuhi; dan dengan memberi kita identitas baru di dalam Dia. Begitu kita melihat kemuliaan-Nya melalui tindakan Kristus menyelamatkan kita, maka kita dapat menyampaikan kasih-Nya kepada dunia di sekitar kita.

Misi gereja adalah untuk pergi ke dunia dan menjadikan murid dengan menyatakan Injil Yesus Kristus dalam kuasa Roh dan mengumpulkan para murid ke dalam gereja, agar mereka dapat menyembah dan menaati Yesus Kristus sekarang dan dalam kekekalan untuk kemuliaan Tuhan Bapa.

Misi gereja, bagaimana kita memahaminya? Apakah kita berbicara tentang gereja lokal sebagai institusi atau gereja sebagai individu yang tersebar di seluruh masyarakat? Bagaimana kita mendefinisikan istilah seperti "mengajar" dan "mengumpulkan" dan "mengirim atau mengutus"? Apakah penting untuk mendefinisikan apakah gereja itu sebelum mendefinisikan apa yang gereja lakukan? Dan mungkinkah mendefinisikan gereja terpisah dari misi Allah? Dalam memikirkan hal-hal ini dan masalah-masalah lain, kita harus cenderung melihat identitas gereja sebagai umat Allah yang dipanggil, "diutus", sebagai kerangka kerja yang menerangi agar bergulat dengan masalah-masalah penginjilan, pembinaan, dan pemuridan.

Misi dan tanggung jawab gereja mencakup proklamasi Injil dan peragaannya. Dari Yesus, kita belajar bahwa kebenaran harus diproklamirkan dengan otoritas dan hidup dalam anugerah. Gereja harus terus-menerus menginjili, menanggapi dengan penuh kasih kebutuhan manusia. Menghayati implikasi-implikasi Injil, gereja misi menawarkan pembelaan verbal dan contoh hidup. Amanat Agung menjadi catatan penting bagi gereja. Bagi Gelder, ${ }^{33}$ "Allah adalah seorang misionaris yang mengutus gereja ke dalam dunia; misi Allah di

${ }^{33}$ Ibid., 4. 
dalam dunia berhubungan dengan Kerajaan Allah; misi gereja adalah suatu tindakan pelayanan inkarnasional (lawan atraksional) untuk terlibat dalam dunia postmodern, postkristeendom, dan konteks global; fokus utama misi gereja adalah setiap orang percaya menjadi murid Kristus dan terlibat dalam dunia.

\section{Fokus Misi Gereja}

Pada umumnya, gereja-gereja, baik kecil maupun besar yang sering disebut "mega church" lebih fokus pada bangunan dan alat (sarana dan prasarana) untuk memuaskan (lebih menekankan sisi entertainitas) jemaatnya dalam pujian dan penyembahan (Praise and Worship) daripada menyenangkan hati Tuhan dengan bermisi dan menjangkau jiwa. Amanat Agung hanya digunakan untuk mengumpulkan dana namun tidak untuk bermisi.

Dengan kata lain, gereja menyuarakan nama Yesus hanya di empat sisi gedung. Minggu demi minggu, pembicara berkotbah, mengajarkan keselamatan kepada orang-orang yang telah selamat. Lebih jauh lagi, orang-orang percaya menghabiskan waktunya dengan sesama Kristen dan menghindari orang-orang yang disebut "orang dunia" yang dianggap sebagai orang yang tidak layak. Kita menolak dengan alasan yang bagus untuk bersentuhan dengan dunia, tetapi apa kata Yesus: bukan orang sehat memerlukan tabib, tetapi orang sakit. Jadi pergilah dan pelajarilah arti firman ini: yang Kukehendaki ialah belas kasihan dan bukan persembahan, karena Aku datang bukan untuk memanggil orang benar, melainkan orang berdosa (Mat. 9:12-13).

Tanggung jawab gereja di dalam dunia adalah diakonia, koinonia dan marturia. Kita semua mengerti tentang tugas gereja tersebut namun apakah ketiga tugas gereja tersebut dijanlankan dengan baik? Apakah gereja benarbenar fokus dengan ketiga tugas tersebut? Bila berbicara jujur, sesungguhnya gereja pada konteks kini hanya melaksanakan dua tugas gereja, diakonia dan koinonia. Bagaimana dengan marturia? Marturia tidaklah lebih dari urusan sosial belaka, memberi makan gratis kepada orang tidak mampu, membiayai 
pendidikan anak-anak yang tidak mampu secara finansial, mendirikan sekolah di tempat-tempat terpencil yang tidak memiliki sekolah, dan lain-lain. Ini berarti fokus gereja telah bergeser dari masalah "sorgawi" ke "sosial". Bila demikian, apa fokus gereja berkaitan dengan marturia? Setidaknya dalam buku ini, tercatat ada dua fokus gereja berdasarkan Alktitab.

Kita telah melihat bahwa Injil adalah fokus utama kehidupan Paulus. Dalam 1 Korintus 9:23 ia mengatakan bahwa ia melakukan "segala sesuatu demi Injil." Dalam Filipi 1, ia menggunakan kata "Injil" enam kali: ayat 5, 7, 12, 16, 27 (dua kali). Dia menyinggung hal itu dalam bahasa lain beberapa kali lagi: "untuk mengucapkan firman Allah" (1:14); "Memberitakan Kristus" (1:15); "Memberitakan Kristus" (1:17); "Kristus diberitakan" (1:18). Fokus Paulus harus menjadi fokus orang Filipi, dan tentu kita: Dia menuntut mereka untuk berdiri teguh dan berjuang bersama "untuk iman kepada Injil."

Untuk memahami misi ini, kita harus memahami dengan jelas tentang apa yang Paulus maksudkan dengan "iman kepada Injil." Dengan "iman," itu berarti iman Kristen, yang menunjuk pada isi Injil. Tanpa kebenaran esensial ini, Injil tidak lagi menjadi Injil. Dalam 1 Korintus 15: 3, 4, Paulus menyatakan isi Injil (15:1), "bahwa Kristus mati untuk dosa-dosa kita sesuai dengan Kitab Suci, dan bahwa Ia dikuburkan, dan bahwa Ia dibangkitkan pada hari ketiga sesuai dengan Kitab Suci. "

Pernyataan singkat ini mengandung banyak kebenaran esensial. Itu memberi kita tentang siapa Kristus, yaitu, Kristus yang dinyatakan dalam Alkitab. Jelas dari lebih dari 300 nubuat mengenai Yesus dalam Perjanjian Lama bahwa Dia adalah Allah yang kekal, yang dapat menebus dosa; dan, sepenuhnya manusia, dalam rupa manusia Ia mati, dan dengan demikian dapat menggantikan dosa kita. Pernyataan Paulus memberi tahu kepada kita kebenaran sentral tentang pekerjaan Kristus, bahwa Ia mati untuk dosa-dosa kita, sebagai pengganti kita. Siapa pun yang menyangkal sifat esensial dari karya substitusi Kristus adalah mengingkari Injil. 
Paulus juga menegaskan kondisi kejatuhan umat manusia, bahwa kita adalah orang berdosa yang membutuhkan seorang Juruselamat. Siapa pun yang mengajarkan kebaikan, sifat dasar manusia adalah mengingkari Injil, karena orang baik tidak membutuhkan Juruselamat. Mereka hanya membutuhkan contoh yang baik dan sedikit dorongan untuk memperbaiki diri. Jika kita tidak membutuhkan seorang Juruselamat, maka Yesus mati tanpa alasan. Injil juga menegaskan kebangkitan tubuh Tuhan Yesus Kristus yang historis dan jasmaniah. Sebagaimana Paulus melanjutkan dalam pasal yang sama untuk menyatakan, "Jika Kristus belum dibangkitkan, imanmu tidak berharga; kamu masih di dalam dosamu "(1 Kor. 15: 7). Kebangkitan adalah bukti bahwa Allah telah menjadikan Yesus sebagai Tuhan dan Kristus (Kisah Para Rasul 2:36), dan bahwa dalam kematian-Nya, Yesus menang atas dosa, maut, dan neraka. Injil datang kepada kita oleh kasih karunia melalui iman terlepas dari jasa atau pekerjaan manusia (Ef. 2: 8, 9).

Dengan kata lain, "iman kepada Injil" melibatkan kebenaran inti tertentu yang tidak boleh dikompromikan. Karena kebenaran ini sangat penting, musuh selalu berusaha membuat kita mempermasalahkannya dengan cara tertentu. Tetapi, untuk memenuhi misi Kristen kita harus berdiri teguh untuk iman Injil. “...Injil adalah kekuatan Allah yang menyelamatkan setiap orang yang percaya..." (Roma 1:16).

Tetapi, juga, untuk memenuhi misi kita, kita perlu mendapatkan fokus kita kembali pada misi itu sendiri, yaitu, berjuang bersama untuk Injil. Harihari ini gereja melakukan misi dengan anggapan misi merupakan bagian dari program gereja, tidak berbeda dengan pelayanan gerejawi lainnya. Padahal misi Amanat Agung adalah inti dan dasar dari gereja. Gereja ada karena pelayanan misi maka dari itu gereja harus bermisi.

"Hendaklah hidupmu berpadanan dengan Injil Kristus..." (1: 27a). Kata Yunani yang diterjemahkan "bersikap baik-baik" secara harfiah adalah, "hidup sebagai warga negara." Itu adalah kata yang sangat berarti bagi orang Filipi. Perlu diketahui bahwa Filipi adalah koloni Romawi, dan orang-orang di sana bangga dengan kewarganegaraan Romawi mereka. Mereka hidup sesuai 
dengan kebiasaan Romawi. Meskipun mereka berjarak sekitar 800 mil dari Roma, mereka tidak berada di bawah otoritas regional apa pun, tetapi menjawab langsung ke Roma, yang diatur oleh hukum Romawi. Mereka adalah pos terdepan Romawi. Paulus mengatakan bahwa orang-orang Kristen, di mana pun kita tinggal secara geografis, harus memandang diri kita sebagai warga negara dari negara lain, yaitu surga. Dengan demikian kita harus hidup secara berbeda dari orang-orang di sekitar kita yang adalah warga dunia ini. Hidup kita harus berpadanan atau sesuai dengan Injil Kristus. Kita berusaha untuk menyenangkan "kaisar" surgawi kita dan hidup dengan hukum-hukum-Nya sebagaimana dinyatakan dalam Firman-Nya. Kita berusaha menyesuaikan karakter dengan Kristus. Meskipun kita juga warga dunia ini, sebagaimana orang Kristen Filipi, kita harus berbeda karena kewarganegaraan utama kita adalah di surga.

Sebagai orang Kristen, kita harus terlibat atau berbaur dengan dunia dalam hal-hal yang tidak melanggar prinsip Alkitab, demi tidak menyinggung orang dan membuka pintu bagi Injil (1 Kor. 9:20-23). Tetapi, meskipun demikian, kewarganegaraan surgawi kita harus menandai kita sebagai berbeda. Kita hidup untuk tujuan yang berbeda. Alih-alih hidup untuk hal-hal dunia ini, kita hidup untuk kerajaan Allah. Kita harus ditandai oleh moral yang berbeda. Kita harus memperlihatkan kualitas karakter yang berbeda, buah Roh. Seperti yang dikatakan Paulus (2 Kor. 5:20), kita adalah duta besar untuk Kristus, yang mewakili kerajaan surgawi-Nya di bumi ini.

\section{E. Misi dan Misionaris}

Para rasul, dalam arti yang luas dari istilah misi, adalah mereka yang telah diutus. Secara kebahasaan, "diutus" juga merupakan hal pertama yang harus kita perhatikan sehubungan dengan istilah misionaris. Bagaimanapun, "ini adalah hal pertama yang Yesus perhatikan tentang misinya-bahwa Ia dikirim untuk mewartakan pesan kabar baik kepada orang miskin (Lukas 4:18). Berada "dalam misi" atau terlibat dalam pekerjaan misi menunjukkan 
intensionalitas dan gerakan"34. Misionaris adalah mereka yang telah diutus dari satu tempat, dan mereka dapat pergi ke tempat lain.

Setiap orang Kristen, jika taat kepada Amanat Agung, maka harus terlibat dalam misi, tetapi tidak setiap orang Kristen adalah seorang misionaris. Memang benar bahwa kita semua harus siap untuk memberikan jawaban atas harapan yang kita miliki, dan kita semua harus menghiasi Injil dengan perbuatan baik kita, dan kita semua harus melakukan bagian kita untuk membuat Kristus dikenal, kita harus tahu bahwa istilah "misionaris" adalah bagi mereka yang sengaja dikirim dari satu tempat ke tempat lain. Penting untuk diingat bahwa gereja (ekklesia) menurut definisi adalah kumpulan dari mereka yang telah dipanggil. Identitas dasar kita sebagai orang percaya bukan sebagai mereka yang diutus ke dunia dengan sebuah misi, tetapi sebagai mereka yang dipanggil dari kegelapan ke dalam terang-Nya yang ajaib (1 Ptr. 2: 9). Kisah Para Rasul, (sebagai tulisan dari Lukas) tidak pernah mencirikan 'gereja' sebagai lembaga yang 'dikirim' untuk mencapai kehendak Allah. Lukas melaporkan bahwa jemaat lokal 'mengirim' pengkhotbah dan pengajar terkemuka sebagai 'misionaris' ke daerah lain (Baca Kis. 13:1-4), tetapi gereja itu sendiri tidak digambarkan sebagai yang 'dikirim'. Karena itu, para misionaris adalah orang-orang unik, tekun, dan sabar, sebab mereka adalah orang-oran yang dipanggil oleh Allah dan diutus oleh gereja untuk pergi dan melanjutkan misi yang belum ditetapkan.

Kembali ke Kisah Para Rasul 14:19-28 untuk menjawab pertanyaan "apa yang dilakukan misionaris?" Harus dicatat bahwa, kitab Kisah Para Rasul adalah tempat terbaik untuk mencari jawaban atas pertanyaan ini, dan bahwa akhir Kisah Para Rasul 14 khususnya adalah tempat yang sangat membantu untuk menjawab pertanyaan ini.

Para Rasul adalah sejarah yang diilhami dari misi gereja. Ini dimaksudkan untuk mengetahui di mana Injil Lukas melalui perintah Yesus

34 Eckhard J. Schnabel, Paul the Missionary: Realitas, Strategis dan Metode (Illionis: Interversity Press, 2008), 27, 28. 
bahwa pertobatan dan pengampunan dosa harus dinyatakan dalam nama-Nya bagi semua bangsa dan dengan janji bahwa Ia akan mengirim Roh Kudus untuk memberikan "perlengkapan" kepada para murid dengan kekuatan dari tempat tinggi sehingga mereka dapat menjadi saksinya (24: 47-48). Narasi yang sama terlihat dalam Kisah Para Rasul 1 ketika gereja berkumpul di Yerusalem menunggu Roh Kudus yang dijanjikan (Kisah Para Rasul 1: 4). Kitab kedua dari Lukas akan menjelaskan apa yang ditugaskan pada akhir Kitab pertama (Injil Lukas) dikirim untuk diselesaikan.

Jangan lewatkan pentingnya Kisah Para Rasul 1: 1: "Dalam Kitab pertama, dikatakan "hai Teofilus yang mulia, saya telah membahas semua yang Yesus mulai lakukan dan ajarkan.” Dengan kata lain, Injil Lukas membahas permulaan pelayanan Yesus, dan sekarang kitab Kisah Para Rasul merupakan realisasi janji dan perintah, dan akan membahas semua yang Yesus terus lakukan dan ajarkan. Kita tidak boleh lupa bahwa kita tidak menggantikan Yesus di bumi, atau bahkan bermitra dengan-Nya dalam arti yang paling ketat. Pekerjaan misi tetap milik-Nya, dan Yesus masih tetap bekerja. Peran kita adalah untuk memberikan kesaksian tentang pribadi dan karya Kristus kepada "dunia. Ini adalah maksud dari Kisah Para Rasul: untuk menunjukkan bahwa para rasul merupakan saksi Kristus di Yerusalem dan di seluruh Yudea dan Samaria, dan sampai ke ujung bumi (1:8). Kisah Para Rasul 1:8 memberi kita daftar isi untuk 28 pasal dalam kitab Kisah Para Rasul. Para rasul akan memberitakan Kristus melalui wilayah-wilayah geografis yang luas, sampai ke bagian paling ujung bumi. Kisah Para Rasul secara eksplisit menjadi sebuah kitab (praktik misi) yang dirancang untuk menunjukkan kemajuan misiInjil di dunia.

Bagaimana dengan pertanyaan di atas? Kisah Para Rasul 14 adalah tempat yang sangat baik untuk mendapatkan jawaban atas pertanyaan itu. Pada awal Kisah Para Rasul 13 gereja di Antiokhia, didorong oleh Roh Kudus, memisahkan Paulus dan Barnabas "untuk pekerjaan yang telah Aku tentukan bagi mereka" (ayat 2). Ayat berikutnya mengatakan, "Kemudian setelah berpuasa dan berdoa mereka meletakkan tangan mereka di atas mereka 
dan mengutus (membiarkan) mereka pergi” (ayat 3). Ini bukan pertama kalinya Injil akan diberitakan kepada orang-orang yang tidak percaya dalam Kisah Para Rasul. Itu bukan pekerjaan Injil pertama yang akan dilakukan oleh Paulus dan Barnabas. Tetapi ini adalah pertama kalinya kita melihat sebuah gereja dengan sengaja mengirim pekerja Kristen dengan misi ke lokasi lain. Paulus dan Barnabas melakukan perjalanan ke Siprus, dan kemudian ke Antiokhia Pisidia, dan kemudian ke Ikonium, dan kemudian ke Listra, dan kemudian ke Derbe, dan dari sana kembali ke Listra, Ikonium, dan Antiokhia Pisidia, dan kemudian ke Perga, dan kembali ke Antiokhia di Suriah. Ini melengkapi perjalanan misi Paulus yang pertama. Jadi Kisah Para Rasul 14:19-28 tidak hanya menjadi ringkasan yang baik dari tugas misionaris Paulus, juga menjadi informasi yang Paulus akan bagikan kepada gereja di Antiokhia ketika ia kembali (ayat 27). Ayat-ayat ini seperti presentasi yang dibagikan oleh Paulus dan Barnabas dengan gereja yang mengutus mereka: "Beginilah cara kami melihat Allah bekerja. Di sinilah kami pergi dan apa yang kami lakukan. Jika ada ayat yang akan memberi kita gambaran yang ringkas tentang apa yang dilakukan misionaris, tentu ayat itu adalah ayat-ayat seperti ini di akhir perjalanan misi dalam Kisah Para Rasul 14.

Kisah Para Rasul 14 memberikan tiga hal yang perlu dicatat berkaitan dengan misi, yaitu:

- Orang yang baru bertobat, "ketika mereka memberitakan Injil ke kota itu dan mendapat banyak murid" (ayat 21).

- Komunitas baru, "Dan ketika mereka telah menunjuk penatua untuk mereka di setiap gereja" (ayat 23).

- Gereja yang dipelihara - "menguatkan jiwa para murid, mendorong mereka untuk terus dalam iman" (ayat 22).

Mungkin ada banyak pekerjaan yang dapat dilakukan oleh misionaris namun semua pekerjaan misi harus mengingat ketiga hal di atas. Jika para rasul dimaksudkan untuk menjadi teladan bagi kita tentang apa yang dilakukan misionaris dan sebagaimana yang diutus dengan Amanat 
Agung, dan kita memikirkan bahwa setiap alasan adalah benar maka kita harus mengharapkan misionaris kita terlibat dalam hal ini. Tujuan dari pekerjaan misi adalah untuk memenangkan orang-orang yang belum mengenal Kristus, mengajar mereka yang baru bertobat, membangun para murid muda ini dalam iman, dan menggabungkan mereka ke dalam gereja lokal.

Schnabel ${ }^{35}$ menguraikan tugas misionaris yang hampir sama dengan tiga hal misi di atas, yakni:

- Para misionaris mengomunikasikan berita tentang Yesus sang Mesias dan Juru Selamat kepada orang-orang yang belum mendengar atau menerima berita ini.

- Misionaris mengkomunikasikan cara hidup baru yang menggantikan, setidaknya sebagian, norma-norma sosial dan pola perilaku masyarakat di mana orang percaya baru telah bertobat.

- Misionaris mengintegrasikan orang-orang percaya baru ke dalam komunitas baru.

Ketiga hal tadi, penginjilan, pemuridan, penanaman gereja menjadi tugas pokok misi dari gereja di Antiokhia untuk dilakukan Paulus dan Barnabas, dan ini harus menjadi tujuan dari semua pekerjaan misi. Para misionaris dapat membidik salah satu komponen ini lebih dari dua komponen lainnya, tetapi ketiganya hendaknya ada dalam strategi misi keseluruhan kita. Pekerjaan pemuridan dan penanaman gereja tidak dapat terjadi kecuali beberapa orang yang belum percaya telah diinjili dan beberapa dari mereka bertobat. Pada saat yang sama, kita tidak dapat meninggalkan orang yang baru bertobat begitu mereka datang kepada Kristus. Mereka harus diajarkan tentang dasar-dasar iman Kristen sebagai fondasi iman dan mengajarkan apa artinya berbalik dari dosa, perbuatan "daging", dan bagaimana mengikuti Yesus. Sebaliknya jika pekerjaan misionaris (misi) kita hanya berfokus pada penginjilan dan pemuridan, tanpa visi untuk sentralitas gereja lokal dan penanaman gereja 
(church planting), kita tidak setia dengan pola yang kita lihat dalam Kisah Para Rasul di mana pertobatan selalu melibatkan penggabungan ke dalam komunitas. Pekerjaan misionaris meliputi ketiga hal tadi dan dapat kita katakan ketiga hal tersebut merupakan tugas pokok misionaris. Ketiga hal itu dapat kita analogikan seperti kursi atau meja berkaki tiga, jika kita kehilangan salah satu kaki maka tentu akan roboh. Demikian jika kita kehilangan salah hal dari ketiga hal misi di atas, maka pelayanan tidak akan sehat, stabil, atau kuat.

Jadi apa yang misionaris lakukan? Misionaris mengkhotbahkan Injil kepada mereka yang belum mendengar Injil. Missionaris memuridkan orang percaya baru dalam kehidupan dan doktrin Kristen. Dan misionaris membangun murid-murid yang baru bertobat menjadi gereja yang sehat dengan pengajaran yang baik dan pemimpin yang baik. Tidak hanya itu, mereka yang melayani sebagai misionaris harus mempertimbangkan apakah prioritas misi Paulus adalah prioritas mereka. Apakah gereja memberikan dukungan finansial bagi misionaris untuk mencapai tujuan misis seperti dalam Kisah Para Rasul 14:21-23? Kisah Para Rasul setidaknya menjadi alat diagnosa bagi pelaksanaan misi masa kini. 


\section{BAB TIGA}

\section{MISI DAN PEMURIDAN}

\section{A. Pendahuluan}

Pemuridan merupakan hal yang tidak terpisahkan dalam tugas pelayanan gereja. Sejak Perjanjian Lama, tugas misi telah ada dan dapat dilihat dari sudut pandang panggilan dan pengutusan Israel. Israel di panggil sebagai bangsa yang mengemban tugas menyatakan Allah kepada bangsa-bangsa lain. Sedangkan pemuridan, dalam konteks Perjanjian Lama harus dilihat sebagai proses keberlanjutan dari misi. Panggilan Allah atas Israel berkaitan dengan pemuridan (praksis pendidikan) dapat dilihat dalam perealisasian panggilan Allah atas bangsa Israel untuk hanya menyembah satu Allah, Allah yang Esa seperti yang ada dalam Ulangan 6:4. Jadi Pemuridan merupakan proses pendidikan (agama) yang bersumber dari Allah dan ditugaskan kepada Israel (PL: Allah kepada Israel), murid-murid Tuhan Yesus dan gereja (PB: Kristus kepada para rasul-Nya dan kepada gereja sebagai tubuh-Nya) ${ }^{36}$.

Perjanjian Lama mengungkapkan beberapa kisah tentang bimbingan satu dengan satu yang ada kemiripan dengan pola pemuridan, di antaranya Musa dan Yosua, Elia dan Elisa. Hubungan ini merupakan hubungan antara sesorang dalam otoritas (master) dan hambanya (disciple) yang menghasilkan proses transfer tanggung jawab kepemimpinan.

Alkitab menyebut Yosua sebagai abdi Musa (Kel. 24:13; 33:11; Bilangan 11:28; Yos. 1:1) dengan berbagai tanggung jawab seperti mendampingi dan menyediakan kebutuhan Musa dan menggantikan kepemimpinan Musa. Musa mengutus Yosua dengan mentransfer sebagian kewibawaannya (Bil. 27:18-23),

36 Bagian ini merupakan artikel yang telah dimuat di Jurnal Te Deum. Noh, Ibrahim, Boiliu, Kesinambungan Panggilan Misionaris Bangsa Israel dengan Panggilan Pelayanan Misi dan Pemuridan, 209-223," Jurnal Te Deum 4, no. 2 (Juni 2015). 
mengajar Yosua dalam berbagai situasi (Ul. 3:21; 31:7-8) dan juga menegurnya (Bil. 11:28-29). Sedangkan hubungan antara Elia dan Elisa lebih mirip hubungan antara guru dan murid (master-disciple relationship) yang mana Elia memanggil Elisa sebagai muridnya (I Raj. 19:16), Elisa mengikuti dan belajar dari Elia dan pada akhirnya Elisa menjadi serupa dengan Elia.Masih banyak contoh dan kisah pemuridan dalam PL namun disiniakan lebih difokuskan pada pemuridan dalam PB khususnya yang dilakukan dan yang diajarkan oleh Yesus. "Konteks rohani di dalam Alkitab praktik pementoran diidentikkan dengan discipleship atau pemuridan di mana Tuhan Yesus juga melakukan pementoran atau mentoring kepada kedua belas murid-Nya" ${ }^{37}$.

Pemuridan adalah metode Tuhan Yesus untuk membangkitkan dan membentuk para pemimpin di mana para pemimpin tidak dihasilkan secara masal, tetapi dibangun melalui sebuah pemuridan pribadi lepas pribadi secara secara kuat, mendalam dan berakar. Selama tiga tahun lamanya Tuhan Yesus memuridkan murid-murid-Nya yang disebut dengan para rasul yaitu Simon yang disebut Petrus dan Andreas saudaranya, Yakobus anak Zebedeus dan Yohanes saudaranya, Filipus, Bertolomeos, Tomas, Matius pemungut cukai, Yakobus anak Alfeus, Tadeus, simon orang Zelot dan Yudas Iskariot.

\section{B. Pemuridan sebagai Tugas Mengajar}

Misi dan pemuridan merupakan hal yang tidak terpisahkan dalam tugas pelayanan gereja. Sejak Perjanjian Lama, tugas misi telah ada dan dapat dilihat dari sudut pandang panggilan dan pengutusan Israel. Israel di panggil sebagai bangsa yang mengemban tugas menyatakan Allah kepada bangsa-bangsa lain. Sedangkan pemuridan, dalam konteks Perjanjian Lama harus dilihat sebagai proses keberlanjutan dari misi. Panggilan Allah atas Israel berkaitan dengan pemuridan (praksis pendidikan) dapat dilihat dalam perealisasian panggilan 
Allah atas bangsa Israel untuk hanya menyembah satu Allah, Allah yang Esa seperti yang ada dalam Ulangan 6:4.

Pemuridan merupakan proses pendidikan (agama) yang bersumber dari Allah dan ditugaskan kepada Israel (PL: Allah kepada Israel), murid-murid Tuhan Yesus dan gereja (PB: Kristus kepada para rasul-Na dan kepada gereja sebagai tubuh-Nya). Dalam Perjanjian Lama, sumber epistemolognya bersumber dari Allah di mana Allah sebagai hakikat pendidikan yang mana persoalan moralitas menjadi dasar dari pengajaran dimaksud. Dengan hanya merujuk kepada Allah, maka Allah menjadi rujukan sumber moral. Dengan demikian, misi bermuara kepada pemuridan dan pemuridan kepada misi. Tidak ada misi yang meniadakan pemuridan sebagai proses mendidik umat mengenal Tuhan secara pribadi dan mendalam yang pada akhirnya menyatakan kembali pribadi Tuhan kepada yang lain.

Dalam segi ini, gereja tidak boleh hanya menekankan misi dan meniadakan pemuridan atau menekankan pemuridan dan meniadakan misi atau tidak menekankan kedua-duanya. Gereja di panggil untuk tugas misi, seperti Allah memanggil Israel dan Kristus memilih para rasul dan membentuk gereja sebagai tubuh-Nya serta mengejawentahkan tugas misi dan pemuridan kepada para rasul dan gereja.

Tidak ada seorang pun yang dapat menafikan hubungan misi dengan pemuridan. Atau menekankan misi dan menolak pemuridan atau sebaliknya. Misi dan pemuridan merupakan dua unsur penting yang harus ada di dalam pergerakan gereja. Namun, kedua unsur ini seolah "mati suri" di tengah perkembangan zaman.

Gereja diperhadapkan dengan berbagai kompleksitas tantangan, terutama tantangan sosial, ekonomi dan politik. Persoalan sosial ekonomi membuat gereja hanya berputar pada misi sosial gereja, yakni memperhatikan orang yang lapar, terpinggirkan, tergusur, bencana alam, dan lain-lain. Bagaimana dengan pemuridan? Pemuridan pun bernasib sama. 
Menurut Greg Oden ${ }^{38}$ bahwa, ketika menghadapi milennium baru, kami mengakui bahwa pertumbuhan gereja saat ini sangatlah dangkal. Semangat kami untuk makin meluas tidak disertai dengan komitmen untuk bertumbuh makin mendalam. Bagaimana mungkin para pemimpin Kristen meratapi degradasi moral yang terjadi dalam masyarakat, padahal ada begitu banyak pribadi yang mengaku memiliki relasi mendalam dengan Yesus Kristus? Jika mereka ialah pengikut Yesus yang sejati, maka kita tidak akan menutup muka dengan rasa malu pada zaman yang telah berbalik dari Tuhan

Masalah kita terletak pada umat Tuhan yang tidak disiplin, tidak dimuridkan, tidak taat, dan yang mengabaikan Firman Tuhan. Bagaimana mungkin para pemimpin Kristen meratapi degradasi moral yang terjadi dalam masyarakat, padahal ada begitu banyak pribadi yang mengaku memiliki relasi mendalam dengan Yesus Kristus? Jika mereka ialah pengikut Yesus yang sejati, maka kita tidak akan menutup muka dengan rasa malu pada zaman yang telah berbalik dari Tuhan Masalah kita terletak pada umat Tuhan yang tidak disiplin, tidak dimuridkan, tidak taat, dan yang mengabaikan Firman Tuhan.

Persoalan-persoalan social yang dihadapi gereja seakan-akan menggiring gereja kepada hanya mencari jalan keluar atas persoalan-persoalan humanitas semata. Gereja harus menyadari hal ini bahwa kita harus taat kepada apa yang katakana Yesus. Yesus sudah mengatakan kepada gereja untuk mandat misi dengan pergi dan menjadikan semua bangsa murid, tetapi ini harus ditaati. J.D. Payne mengatakan bahwa "The commission for missionaries to make disciples of all nations begins with calling others to repentance and faith in Jesus. But, it does not end there. This commission also involves teaching these new Kingdom citizens to obey all of Jesus' commands (Matt 28:20)"39. Artinya, gereja tidak hanya tahu bahwa di dalam Alkitab atau Yesus pernah mengatakan bahwa pergi dan jadikan semua bangsa murid melainkan bagaimana mengajar orang untuk menerapkan apa yang telah Yesus perintahkan.

38 Greg Oden, Pemuridan yang Mengubahkan (Surabaya: PERKANTAS, 2014).

39 J. D. Payne, Discipleship in Church Planting: Some Guidelines to Move Us Forward (USA: Good News Publisher, 2011), 7. 


\section{Memuridkan sebagai Upaya Melahirkan Pemimpin dalam Gereja}

Pada point terakhir ini, saya memang hanya mengemukakan hubungan misi dengan pemuridan. Namun ketika kita memahami pentingnya permuridan maka kita tidak hanya berhenti pada pemuridan itu sendiri melainkan dapat melahirkan pemimpin-pemimpin dalam gereja. Jim Putman, ${ }^{40}$ mengatakan bahwa gereja membutuhkan pemimpin-pemimpin karena itu gereja harus menerapkan pemuridan untuk melahirkan pemimpin. Alasan Putman hanya sederhana berkaitan dengan pemuridan dan pemimpin yakni, setiap orang percaya yang telah dimuridkan dan dewasa secara rohani maka ia layak untuk dipercayakan tanggungjawab-tanggungjawab rohani. "I want the process of finding and developing good leaders to be simple and reproducible so that our church can become purposeful and effective at making disciples and leaders...and effective reproducing culture is created when leaders believe in something strongly enough to live out those principles..." ${ }^{41}$. Bahkan Putman memberikan contoh bahwa dalam pelayanannya di Real Life Ministry, para pemimpin-pemimpin (pastors and missionaries) dapat mengelola gereja karena memiliki kemampuan dan kepribadian yang kuat di dalam Kristus. Karena itu, discipleship is one who committed to Jesus mission to save people from their sin-God mission is our mission (hand); One who being changed by Christ (heart)-Mat. 7:17-20; One who following chirst (head)"42. Pemuridan adalah seseorang yang membagikan kehidupannya bagi orang lain yang baru percaya demi menolong mereka untuk mengenal dan memperkenalkan Kristus. Kristus membagikan hidupnya kepada murid-muridNya selam 3,5 tahun. Yesus tidak takut jika gereja tidak maju, bahkan mati. Yesus hanya mengerjakan pemuridan karena pemuridan bersifat reproducible.

Perintah Yesus dalam Matius 7:17-20, "Karena itu pergilah, jadikanlah semua bangsa murid-Ku dan baptislah mereka dalam nama Bapa dan Anak dan

\footnotetext{
40 Jim Putman, Building Churches that Make Disciples (Colorado: NavPress, 2010), 165168.

${ }^{41}$ Ibid.

42 Ibid., 32.
} 
Roh Kudus," dan ajarlah mereka melakukan segala sesuatu yang telah Kuperintahkan kepadamu." Sesuai struktur tata bahasa aslinya (Yunani), kalimat induk dalam Amanat Agung adalah "Jadikanlah semua bangsa muridKu. "Kata : pergilah... baptislah ... ajarlah merupakan kata kerja yang bergantung pada kata kerja utama jadikanlah ... murid-Ku.

Perhatikanlah, berdasarkan Matius 7:17-20, kita mendapati satu amanat, Jadikanlah semua bangsa ----- kuantitas muridKu -.-.-- kualitas dengan tiga tahap,

Baptislah --.-- Penginjilan
Ajarlah ------ Pembinaan
Pergilah --.--- Pengutusan

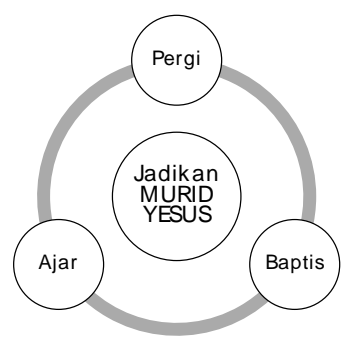

Jika kita memperhatikan dengan saksama perintah ini maka kata pergi berada di awal dan berada di akhir, yakni pergilah, baptislah, dan ajarlah, setelah itu harus pergi. Sebab itu, pemuridan memberikan dampak positif. Setidaknya dampak positif yang diperoleh adalah:

- Menyiapkan dan membangun suatu generasi yang kuat

- Menghasilkan Pemimpin-pemimpin Rohani yang dewasa dan berkarakter seperti KristusMengantisipasi Krisis Kepemimpinan

- Menciptakan Proses Multiplikasi atau Pelipatgandaan

- Kita sendiri akan mengalami pertumbuhan baik dalam kesetiaan, kesabaran, ketekunan, keuletan, hati Bapa, Hikmat Untuk menasehati, dll

Jika sebaliknya tidak menerapkan pemuridan maka para pemimpina diperhadapkan dengan krisis-krisis kepemimpinan dan krisis pemimpin dalam gereja.

Jadi, sejak di Perjanjian Lama saat Allah memilih Israel dalam kovenanNya sebagai umat pilihan-Nya, Allah juga telah menetapkan rencana-Nya di mana Israel tidak hanya menjadi bangsa yang menerima Kanaan sebagai negeri yang dijanjikan dengan berdiam diri melainkan menerima Kanaan dengan 
tanggungjawab memperkenalkan YHWH kepada bangsa-bangsa yang belum mengenalnya. Tugas ini merupakan inti berita dalam penetapan Israel sebagai umat pilihan.

Keberlanjutan tugas memperkenalkan Allah kepada bangsa-bangsa yang tidak mengenal Allah tidak semata-mata pada Israel (inipun karena kedegilan hati mereka). Penetapan dan pengutusan Israel ke Kanaan hanya merupakan langkah awal Allah dalam rencana-Nya. Sejak kehadiran Kristus di bumi, babak baru tentang tugas terbut pun terkuak. Pelayanan Yesus selama 3,5 tahun merupakan keberlanjutan dari rencana Allah dan bagaimana program Allah dapat berjalan dengan baik maka Yesus membangun system yang berkelanjutan yakni pemuridan yang bersifat reproducible. Dengan menunjuk pada Matius 7:17-20 Yesus memberikan perintah tentang keberlanjutan tugas dan tanggungjawab memperkenalkan Allah kepada bangsa-bangsa lain yang belum mengenal Allah. Tugas tersebut dalam catatan Matius berkesinambung dalam satu tema dengan Kisah para Rasul 1:8.

Yesus memperkenalkan prinsip pemuridan dan keberlanjutan misi sebagai langkah-langkah dalam membangun dan menciptakan sumber daya manusia untuk tugas dimaksud. Pemuridan kemudian menjadi "jiwa" dari pelayanan Yesus. Sebab selama 3,5 tahun Yesus memberikan teladan tentang bagaimana membangun gereja yang kuat dan berkelanjutan yakni "pergilah, baptislah dan ajarlah".

Pemuridan kemudian dilihat oleh beberapa orang pada masa kini sebagai jalan menciptakan pemimpin-pemimpin dalam misi dan pelayanan pastoral. Pemuridan pun kemudian dilihat sebagai jalan keluar atas "tekanan" yang dialami pemimpin-pemimpin gereja, jalan keluar atas krisis-krisis kepemimpinan dan krisis pemimpin. Tetapi mengapa banyak gereja yang meskipun pemuridan merupakan perintah Yesus namun tidak diterapkan? Dan membiarkan pemuridan "mati suri" atau dalam ungkapan Leroy Eims, Pemuridan, Seni yang Hilang. 


\section{BAB EMPAT}

\section{PERJUMPAAN MENUJU PERTOBATAN}

\section{(Perjumpaan Rasul Paulus Dengan Kristus Pneumatis Sebagai Titik Kulminasi Religiusitasnya ${ }^{43}$ )}

\section{A. Permasalahan dan Pendekatan Fenomenologi}

Bagian ini merupakan pendekatan fenomenologis terhadap perjumpaan rasul Paulus dengan Kristus pneumatis. Peran Rasul Paulus dalam misi Kristen tidak dapat dinafikan. Sebelumnya, Paulus yang adalah Saulus, memiliki kapasitas akademis yang mumpuni. Pengetahuannya yang mumpuni ternyata tidak berbading lurus dengan pengenalannya terhadap Tuhan. Paulus justru berada pada "jalan yang menentang Tuhan". Hingga akhirnya ia mengalami perjumpaan dengan Kristus, ketika dalam perjalanan menuju Damsyik (Damaskus). Juga ingin menfsirkan pengalaman pertemuan Paulus dengan Kristus melalui fenomenologi agama dan menggambarkannya secara biografis (historis). Metode yang dipakai adalah kepustakaan dengan pendekatan analisis fenomenologis historis-hermeneutis.

Perjumpaan itulah yang hendak dianalisis dengan pendekatan fenomenologis. Perjumpaan Paulus dengan Kristus itulah yang hendak dimaknai sebagai perjumpaan yang membawa kepada pertobatan. Sesungguhnya misi Allah adalah mencari dan menjumpai manusia yang berdosa atau "sakit". Paulus "dalam kondisi terhilang" dan Kristus "sebagai misionaris" menjumpainya.

Diharapkan setiap umat Tuhan dapat memiliki pemahan yang benar tentang imannya yang ditunjukkan dalam kemanunggalingan hidup dengan

\footnotetext{
43 Bagian ini sebelumnya dimuat di Jurnal Stulos. Noh Ibrahim Boiliu, "Perjumpaan Rasul Paulus Dengan Kristus Pneumatis Sebagai Titik Kulminasi Religiusitasnya", Jurnal Stulos 3, no. 13 (April 2014), 97-118.
} 
Kristus maka akan membawa dampak terhadap nilai dan kualitas spiritual yang dapat mewujud dalam pola laku keseharian di masyarakat seperti yang diteladankan Rasul Paulus. Bertolak dari hasil di atas maka penulis menyarakan agar setiap umat Tuhan membenahi, membangun dan memantapkan pemahaman keimanan tentang Kristus sehingga membawa perubahan bagi diri dan lingkungan masyarakat.

Fenomena perjumpaan Paulus dengan Kristus pneumatic seperti yang tercatat dalam Kisah para Rasul 9:1-9a menarik untuk diteliti. Sebab dalam waktu yang tidak lama pasca perjumpaannya, Paulus mengalami perubahan yang signifikan baik dalam cara pandangnya terhadap Kristus maupun terhadap agama Yahudi.

Penyelidikan ini difokuskan pada fenomena perjumpaannya dalam perjalanan ke Damaskus (Damsyik). Tujuannya adalah untuk mengungkap makna (verstehen) melalui fenomen-fenomen yang ada. Sehingga dari temuan makna terhadap fenomen-fenomen kita dapat menarik hubungannya dengan kehidupan spiritual kita. Baik yang bersifat reflektif spiritual maupaun terapan dalam konktes fenomenologi. Karena itu, saya akan mengawalinya dengan memaparkan pendekatan fenomenologis, kemudian penerapan metode fenomenologis dalam fenomena perjumpaan Paulus dalam perjalanan ke Damaskus (Damsyik). Dan diakhiri dengan hasil penerapan metode fenomenologis

Kata fenomenologi mengacu pada istilah Yunani phainomenon atau phainesthai yang artinya menampakkan atau memperlihatkan. Phainomenon memiliki arti "objek persepsi, apa yang diamati, apa yang tampak pada kesadaran kita, pengalaman inderawi, apa yang tampak pada panca indra kita dan peristiwa yang dapat diamati" 44 . Atau, "sesuatu yang menampilkan diri, sesuatu yang tampak, terlihat karena bercahaya dalam bahasa Indonesia

44 Save M. Dagun, Filsafat Eksistensialisme (Jakarta: Rineka Cipta, 1990), 37. Bandingkan dengan, Lorens Bagus, Kamus Filsafat (Jakarta: Gramedia, 2007), 234-239. 
biasanya disebut gejala. Gejala tersebut bisa dipertentangkan dengan kenyataan karena memang fenomena (gejala) bukanlah hal yang nyata”.

Peralihan fokus Husserl dari objek kepada kesadaran karena "kesadaran" merupakan "asal kenyataan”. Ini berarti yang ada hanya subjek yang sadar sehingga dengan demikian Husserl menolak bipolaritas dan fenomenologinya menjadi "fenomenologi transcendental". Peralihan ini sekaligus mendekatkan Husserl pada idealisme Hegelian. Ini juga merupakan suatu pembiasan, di mana fenomenologi berusaha menyusun langkah-langkah yang sistematis dan memberikan dasar yang tak terbantahkan oleh ilmu pengetahuan. Tujuannya adalah untuk mengangkat eksistensi manusia dan pengalaman asazi manusia dan melawan empirisme dan psikologisme. Inilah tujuan semula. Namun dalam perkembanganna, ada kecenderungan pada metode fenomenologi sehingga Husserl gagal mengangkat persoalan-persoalan eksistensial yakni persoalan antara ada dengan dunia yang nampak.

Untuk menangkap hal tersebut atau dengan kata lain untuk menganalisisnya maka diperlukan metode. Metode yang dipergunakan adalah metode fenomenologis. Joko Siswanto dalam bukunya "Metafisika Sistematik" mengatakan bahwa "untuk membongkar atau menganalisis struktur eksistensial ini metode yang digunakan adalah metode "fenomenologi eksistensial"45 yang baginya metode ini sama dengan atau identik dengan "lingkaran hermeneutis"46. Metode fenomenologi digunakan untuk mengungkap makna dan hakikat tetapi di manakah kita menemukan makna dan hakikat fenomena itu? Slogan yang biasanya diungkapkan oleh penganut paham fenomenologi adalah zu den sachen lebst artinya terarah pada benda itu sendiri. Dalam keterarahan kepada benda tersebut maka benda itu sendirilah yang akan mengungkapkan dirinya sendiri; yang terungkap melalui fenomen-fenomen.

Dalam konteks ini, tentu manusia tidaklah sama dengan benda. Tetapi metode yang digunakan untuk mengungkap eksistensi manusia adalah sama.

45 Joko Siswanto, Metafisika Sistematik (Yogyakarta: Taman Pustaka Kristen, 2004), 46.

46 Ibid., 46. 
Manusia adalah manusia yang tidak lepas dari dunia bahkan dari manusia lain. Dalam perkataan yang lain manusia terbuka bagi dunia dan manusia lain (sesamanya). Dengan adanya keterbukaan tersebut sangat diperlukan "kepekaan, pemahaman dan komunikasi" maka sangat memungkinkan bila muncul rasa senang, kecewa dan lain-lain. Ini merupakan suasana batin. Suasana batin tersebut diungkapkan melalui fenomen-fenomen untuk membangun pemahaman (verstehen) kita.

Karena itu, fenomenologi berangkat dari beberapa afirmasi berikut:

1. Pemerikaan Filosofis tidak bisa dimulai kecuali dari fenomena kesadaran, sebab hanya fenomena itulah yang tersedia bagi kita, dan hanya fenomena itulah bahan yang bisa digunakan segera oleh kita. Maka jelas bahwa fenomenologi menggunakan kesadaran sebagai titik acuan awal untuk melakukan segala sesuatu.

2. Hanya fenomena itulah yang membukakan kepada kita apa esensi sesuatu itu. Esensi yang dimaksudkan disini adalah hakikat dari sesuatu itu. Kesadaranlah yang kemudian melakukan identifikasi terhadap sesuatu itu mendapatkan hakikatny secara murni.

Husserl mengatakan bahwa pendekatan yang mungkin untuk mengetahui berbagai hal (fenomena) adalah dengan cara mengeksplorasi kesadaran manusia. Inilah yang sebetulnya menjadi inti (prinsip) fenomenologi yaitu eksplorasi yang sistematik dan penuh atas kesadaran manusia.

Kesadaran memiliki begitu banyak fenomena dan itu amatlah beragam. Apakah itu kejadian, manusia, pengalaman, ingatan, moods (suasana hati) dan lain-lain. Maka fenomenologi mencatat semua fenomena itu lalu mengeksplorasinya melalui suatu metode khusus yang disebut metode fenomenologis.

Sekalipun demikian untuk mengungkap sesuatu yang asali, kita harus sedikit tidak menghiraukan atau dengan perkataan lain tidak berhenti sampai pada apa yang kita tangkap dalam fenomena itu melainkan menerobos batasbatas fenomena sehingga di sana kita menemukan "apa adanya dalam dirinya" 
apa yang ada di hadapan kita. Keterarahan kepada benda itu sendiri tidak secara langsung membuat fenomena itu mengungkapkan hakikatnya. Edmund Husserl menyebut tahap ini sebagai the first look. Bagi Husser ${ }^{47}$, bila pengamatan pertama tidak sanggup membuat fenomena itu mengungkapkan hakikatnya maka diperlukan pengamatan kedua atau the second look. Pengamatan kedua ini disebut pengamatan "intuitif". Pengamatan intuitif sendiri harus melewati tiga tahap reduksi. Yakni reduksi fenomenologis, eidetic, dan transendental. Inilah metode pendekatan yang dikemukakan Edmund Husserl berkaitan dengan pendekatan dalam mengungkap hakikat fenomena. Pemikiran Husserl sendiri cukup mempengaruhi pemikiran para eksistensialis.

Dengan demikian maka ada tiga jenis reduksi yang digunakan, yakni:

- Reduksi fenomenologis. Melalui reduksi ini manusia mesti meninggalkan(menyaring) pengalaman-pengalamannya untuk mendapatkan fenomena dala wujud murni dan utuh. Hal ini perlu dilakukan supaya fenomena yang diselidiki bisa masuk kedalam kesadaran, tanpa terlebih dulu di-judge oleh pengalaman. Apabila reduksi ini berhasil maka manusia dapat menemukan fenomena atau gejala yang sebenarnya. Manusia akan mengenal gejala tersebut dalam dirinya sendiri.

- Reduksi eidetic. Merupakan tindakan pengurungan (penyaringan) segala hal yang bukan eidos atau intisari atau hakekat fenomena. Jadi disini bisa disebut sebagai penilikan hakekat. Disinilah manusia bisa memengerti sesuatu dalam konteks hakikatnya. Umpamanya kalau manusia menyelidiki fenomena rumah, maka haru dilakukan penyaringan, mana yang merupakan inti sari rumah dan mana yang bukan.

- Reduksi transcendental. Reduksi ini melakukan penyaringan terhadap eksistensi dan segala sesuatu yang tiada hubungan timbal balik dengan kesadaran murni, agar dari obyek itu akhirnya orang sampai kepada apa yang ada pada subyek sendiri atau dengan kata lain metode fenomenologi

47 Jan Hendrik Rapar, Pengantar Filsafat (Yogyakarta: Kanisius, 2005), 119. 
diterapkan kepada subjeknya sendiri dan kepada perbuatannya, kepada kesadaran yang murni.

\section{B. Fenomena Perjumpaan Paulus}

Paulus merupakan rasul Kristus (bukan langsung) yang "fenomenal". 48 Proses Paulus menjadi rasul tidak seperti dua belas rasul lainnya yang dipilih secara langsung oleh Kristus semasa dalam pelayanan-Nya di bumi. Paulus menjadi rasul diawali dari perjumpaannya dengan Kristus dalam perjalanan ke Damsyik.

Kisah perjumpaan Paulus (kala itu disebut Saulus) dengan Kristus terjadi secara personal. Perjumpaan itu mempertemukan dirinya dengan Kristus "pneumatis". Perjumpaan itu tidak diwakilkan oleh siapapun dan bersifat ekistensialistik.

Pasca-perjumpaan dalam perjalanan ke Damsyik, Paulus berada dalam satu dimensi spiritualitas yang baru dan saya menyebutnya sebagai berada dalam "religiusitas yang eksistensial" 49 . Henderick Copleston dalam Ostina Panjaitan, mengatakan bahwa "an existing individual is himself in process of

48 Fenomenalitas ini saya lihat dari kompleksitas padangan teolog maupun non teolog terhadapnya. Sehingga, Misalnya F.C Bauer dari aliran Tubingen dengan konsep Paulus Hegelian, H.J. Holtzman dari aliran Liberal dengan konsep Paulus liberal, Paulus mitis dari aliran sejarah agama dan Paulus eksistensialis dari Bultmanian yang berakar pada aliran Heidegerian. Metode-metode pendekatan yang ditawarkan di atas merupakan metode- metode bentuk modern yang lebih berorientasi metode sains. Lihat, Herman Riderbos, Paulus: Pemikiran Utama Theologinya (Surabaya: Momentum, 2008), 1-34.

${ }^{49}$ Noh Ibrahim Boiliu, "Religiusitas Eksistensial Manusia 247-261," Jurnal Te Deum 2, no. 2 (Juni 2013): 247-261, Wilfred Cantwell Smith mengatakan bahwa keyakinan eksistensial merupakan kemampuan untuk hidup pada suatu taraf yang tidak bersifat duniawi, kemampuan untuk melihat, merasakan dan bertindak dalam suatu dimensi transenden”. Sedangkan James Fowler dalam mengembangkan teori Faith Development Theory mengatkaan bahwa keyakinan ekistensial Suatu keyakinan yang bersifat personal. Personal bukan berarti lepas dari yang lain. Juga merupakan "suatu kualitas hidup manusia. Dalam situasi yang paling baik, kepercayaan eksistensial, terungkap dalam ketenangan hati dan keberanian, kesetiaan dan sikap melayani; kegembiraan yang tenang, yang menyanggupkan kita untuk merasa kerasan di tengah alam semesta dan menemukan makna hidup di tengah dunia serta dalam kehidupan kita sendiri ; suatu makna yang sangat dalam dan ultimo serta senantiasa stabil, apapun yang terjadi pada atas diri seseorang pada tingkat peristiwa-peristiwa actual.49 Iman atau keyakinan eksistensial, tidak hanya bersifat personal, tetapi merupakan suatu kehidupan spiritual yang mendalam, tenang dan teguh ketika dalam situasi apapun. Mencari dan 
becoming...in existence the watchword is always foreword"50. Bahwa keberadaan individu adalah proses yang terus menerus. Bahkan eksistensi adalah "the child that is born of the infinite and the finite, the eternal and temporal, and is therefore a constant striving"51. Eksistensi lahir dari yang tak terbatas, yang kekal (eternal) dan sementara (temporal) dan berlangsung terus-menerus. Dan Soren Kierkegaard mengatakan bahwa "hubungan sejati manusia dengan Allah akan membawanya mencapai eksistensinya yang sejati"52. Atau kesejatian eksistensi manusia sejauh manusia berada dalam hubungan yang sejati (eksistensial, personal, tanpa topeng, tanpa kemunafikan, atau ketenangan hati dan keberanian, kesetiaan dan sikap melayani; kegembiraan yang tenang)

Bahkan, Martin Heideger, memandang bahwa "esensi manusia terletak dalam eksistensinya"53 Dalam hal ini, Heideger memlihat manusia sebagai makhluk yang terus bergerak atau terus mengaktualisasikan diri. Aktualisasi diri manusia (self-actualisation) pun akan terungkap dalam cara beradanya (eksistensinya).

Dalam segi ini, Paulus sebagai orang yang mengalami perubahan pasca perjumpaannya dengan Kristus tentu menunjukkan aktualisasi dirinya sebagai manusia "bertuhan" maka esensi diri sebagai yang "ber-Tuhan" terlihat dalam cara "laku" atau cara berada. Bahkan dapat dikatakan bahwa ada "reaktualisasi keyakinan Paulus sebagai manusia ber-Tuhan". Yang dimaksudkan dengan reak tualisasi di sini adalah awalnya Paulus memang adalah manusia bergama (homo religion) yang giat dengan kegiatan keagamaannya namun pasca perjumpaan itu, ia mengalami perubahan paradigma dalam segi keberagamaannya dan ia tunjukkan melalui "laku" sikap diri, konsep diri (self consept), pengetahuan (knowledge). Hal ini kita tangkap dari ungkapan Paulus "semua yang dahulu adalah sampah". Inilah yang juga saya setujui dari

50 Frederick Copleston, Â History of Philosophy: Fichte to Niestzsche (London: Search Press, 1963), 348.

51 Ibid.

52 Ostina Panjaitan, Manusia sebagai Eksistensi. Menurut Pandangan Soren A. Kierkegaard (Jakarta: Yayasan Sumber Agung, 1996), 9.

${ }^{53}$ Ibid., 16. 
pernyataan Kierkegaard bahwa hubungan sejati manusia dengan Allah akan membawanya mencapai eksistensinya yang sejati.

Perjumpaan itupun kemudian tidak (melulu) menjadi pengalaman supranatural yang tidak dapat dimaknai dalam alam natural manusia. Pengalaman supranatural rasul Paulus dalam perjumpaannya dengan Kristus "pneumatis"54 dapat dimasuki dimensi spiritualitasnya melalui "sikap rasul Paulus terhadap Kristus" 55 dan tulisan-tulisan rasul Paulus. Dalam konteks perjumpaan Paulus yang kemudian membentuk konsep diri, konsep keagamaan dan teologinya inilah saya ingin membentangkannya meski singkat. Oleh karena dua pokok permasalahan ini, pengalaman religius Paulus dan tulisantulisan Paulus (yang telah dikanonkan menjadi tulisan yang berotoritas sebagai Firman Tuhan) berada dalam kajian fenomenologis. Saya memasukan kajian atas "lapangan pengalaman Paulus" dan "tulisan-tulisan Paulus" sebagai dua hal yang mengkristal dalam istilah "religiusitas" 56 baik "fenomenologi" 57

54 Saya menggunakan istilah ini dalam konteks membedakannya dengan situasi Kristus saat di bumi. Tujuannya adalah agar ketika mengatakan Paulus berjumpa dengan Kristus (tanpa pneumatic) maka pembaca masih harus berpikir dan menafsir apakah Paulus pernah berjumpa secara fisik dengan Yesus. Karena itu saya menggunakan istilah pneumatis untuk menunjukkan bahwa pengalaman bersama Kristus di Damsyik tidak fisis.

55 Bandingkan sikap Paulus pra dan pasca perjumpaan dengan Kristus pneumatis

${ }^{56}$ Istilah religiusitas: Bandingkan dengan, Wilfred C. Smith, Memburu Makna Agama (Bandung: Mizan, 2004). Dan, K. Prent, dkk, Kamus Latin-Indonesia (Yogyakarta: Kanisius, 1969), 733. Menerjemahkan kata religiusitas sebagai agama, kesalehan. Sedangkan dalam catatan kaki dari Smith, kata ini diturunkan dari kata relegare yang berarti yang cermat dan saksama dalam melaksanakan pemujaan...Smith juga menunjukkan kajian-kajian terbaru seputar itulah ini bahwa berdasarkan catatan Katzler bahwa bukan hanya kata relegarelligare, 'mengikat', dan bukan pula legere, 'menghimpun, mengkaji, membaca'. Namun ada akar kata ketiga yaitu lig yang memiliki hubungan dengan kata Yunani alego, 'memberikan perhatian, memberikan kepedulian'. Dalam hal ini, saya mengartikan religiusitas sebagai sikap iman. Yang mana sikap iman merupakan bagian dari religio yang oleh Smith dilhat sebagai yang memiliki sistem yang dapat diperiksa melalui ritus, konsep Tuhan, korban, dll. Meski istilah ini ditolak oleh Fowler (mengembangkan teori Faith Development Theory. Pendekatan Fowler adalah fenomenologi psikologis kepercayaan) yang lebih menerima istilah kepercayaan eksistensial ketimbang keagamaan. Lihat, Agus Cremers (Alih) dan A. Spratiknya (edit), Teori-teori Perkembangan Kepercayaan. Karya-karya Penting James W. Fowler, Yogyakarta: Kanisius, 1995. Karya Fowler ini juga yang memberikan inspirasi seputar religiustas eksistensial Rasul Paulus.

${ }^{57}$ Lihat, Mariasusai Dhavamony, Fenomenologi Agama, Yogyakarta: Kanisius, 2010, h. 544. Dalam pendekatannya, fenomenologi dapat digunakan pda bidang antropologi, sosiologi, psikologi, dan studi-studi agama (lihat halaman 6). 
"historis"58 maupun "hermeneutis"59. Dengan demikian, metode fenomenologis historis-hermeneutis digunakan sebagai metode pendekatan.

Penggunaan metode ini karena "metode ini mencoba menangkap dan menginterpretasikan setiap jenis perjumpaan manusia dengan yang suci". ${ }^{60}$ Karena itu "metode fenomenologis tidak hanya menghasilkan suatu deskripsi mengenai fenomena yang dipelajari, sebagaimana yang diperkirakan, tidak juga menerangkan hakikat filosofis dari fenomena itu; sebab fenomenologi agama bukanlah deskriptif atau normative belaka...metode ini memberikan kepada kita arti yang lebih dalam dari suatu fenomena religius, sebagaimana dihayati dan dialamai manusia-manusia religius". ${ }^{61}$

Interpretasi (hermeneutis) menjadi catatan penting kala berhadapan dengan pengalaman azasiah religius rasul Paulus. Perjumpaan rasul Paulus dan tulisan-tulisan rasul Paulus menjadi pengamatan (objek). Dunia kehidupan (lebenswelt) religius rasul Paulus menjadi realitas yang ditangkap dan dinyatakan dalam data teks bahkan pengalamannya menjadi realitas tersendiri

${ }^{58}$ Bandingkan dengan, Jan S. Aritonang, Berbagai Aliran di dalam dan di Sekitar Gereja (Jakarta: BPK Gunung Mulia, 2012). Profesor Aritonang, tepat menggunakan metode pendekatan fenomenologis historis pada kajian Sejarah Gereja. Karena benar bahwa yang hendak dikaji adalah fenomena gereja dalam sejarah. Karena memang Sejarah Gereja masuk dalam kajian fenomenologi historis agama (bandingkan dengan Dhavamoni, halaman 32). Yang hendak diungkap dengan metode pendekatan ini adalah (data) lapangan pengalaman manusia (fenomenon) untuk mengungkap realitas dibaliknya (noumenon). Bandingkan juga dengan, Anton Baker dan Achmad C. Zubair, Metodologi Penelitian Filsafat (Yogyakarta: Kanisius, 2005). Perhatikan halaman 41, "dalam pelaksanaan segala macam penelitian seorang peneliti akan berhadapan dengan kenyataan. Dalam kenyataan itu dapat dibedakan beberapa aspek. Bias berbentuk fakta dan data...kennyataan berbentuk gejala...sedangkan ilmu-ilmu sosial, si peneliti pertama dan terutama berhadapan dengan manusia hidup, dengan tingkah lakunya, agamanya, kebudayaannya, bahasanya, struktur sosialnya, kebaikannya dan dosanya. Saya lihat, saya dengar, atau meraba-raba suatu fakta namun fakta itu diketahui tidak hanya secara fisik: kulit, besar, sehat. Fakta itu saya tangkap sebagai suatu ekspresi manusia...dalam ekspresi itu dibaca dan ditangkap arti, nilai, maksud human.

59 Bandingkan dengan, Noh Ibrahim Boiliu, "Penerapan Hermeneutika Fenomenologis pada Penelitian Teologi: Diskursus tentang Metode Ilmiah Teologi”, Jurnal Stulos, 12, no. 2 (2013). Bandingkan dengan, F. Budi Hardiman, Melampaui Positivisme dan Modernitas. Diskursus Filosofis tentang Metode Ilmiah dan Problem Modernitas (Yogyakarta: Kanisius, 2007). Nah, berbeda metodologi bila melakukan kajian dalam ilmu naturwissenschaften dan Geistenswissenschaften. Wilhelm Dilthey membedannya dengan dua istilah Erklaren-penjelasan dan Verstehen-pemahaman. Karena itu, hermeneutika merupakan fenomena khas manusia. Dengan demikian, metode fenomenologis hermeneutis dapat digunakan untuk memahami pengalaman religious manusia yang Nampak dalam sikap dan tulisan.

${ }_{60}$ Mariasuasi Dhavamony, Fenomenologi Agama, 42

${ }^{61}$ Ibid., 43. 
yang meski sudah terungkap lewat data tekstual (surat-surat kirimannya) namun pengalamannya yang kita tangkap sebagai fenomena psikologis religius dapat kita ungkapkan tetapi "yang lainnya" mungkin kita hanya bisa memahaminya.

Langkah pertama, kita memeriksa terlebih dahulu fenomena keagamaan Paulus pada masa pra perjumpaan. Tujuannya adalah agar kita dapat melihat perbedaan fenomena antara pra dan pasca perjumpaan.

\section{Pra Perjumpaan}

Paulus yang semula bernama Saulus ${ }^{62}$ adalah pemuda yang berlatar belakang Yahudi. Ia berasal dari golongan Farisi atau salah satu partai nasionalis dalam Yudaisme yang terkenal sangat keras. Ia dilahirkan di kota Tarsus, daerah Kilikia; salah satu kota yang cukup terkenal di Asia kecil. Dan di Tarsus-lah Paulus kecil menghabiskan masa kanak-kanaknya. Sesuai tradisi Yahudi, setiap anak laki-laki harus belajar tentang tradisi-tradisi Yahudi dan kitab-kitab. Di samping itu, ia pun belajar membuat tenda, yang mana dalam (kemungkinan) kurikulum, siswa tidak hanya belajar menuntut ilmu melainkan juga keterampilan.

Ia kemudian pindah ke Yerusalem untuk menempuh studi di sana. Kepindahan Paulus dikarenakan, orang tuanya tidak ingin anaknya hidup di kota yang penuh dengan kekafiran. Bahkan, bagaimanapun juga fanatisme orang tua Paulus begitu kuat (orang Yahudi pada umumnya) di mana tidak juga menginginkan anaknya terkontaminasi dengan budaya dan pemikiran Yunani. ${ }^{63}$ Meskipun sulit memungkirinya, sebab Tarsus merupakan salah satu kota perdagangan, bisnis dan pendidikan tinggi, sehingga setiap anak yang berada di kota itu lambat laun terpengaruh ole hide-ide Yunani yang kafir.

62 Saulos (Greek), nama Yahudinya Saulus

${ }^{63}$ Bandingkanlah dengan Thomas Alfa Edison. Ia berlatarbelakang Yahudi. Orang tuanya meminta guru Yahudi untuk mengajarkan agama Yahudi kepadanya. 
Yerusalemn merupakan pusat dunia Yahudi. Karena itu, Paulus dikirim ke kota ini untuk belajar pada Raban"64 Gamaliel.65 "Gamaliel, cucu Hillel merupakan pengganti Rabi Hillel - 60 sM - M". Dalam tradisi Yahudi, ada dua aliran sekolah yang memiliki kredibilitas akademis yakni bet hillel dan bet syamai. Kedua aliran ini memiliki metode pendekatan yang berbeda. Pasca kehancuran Yerusalem tahun 70, banyak sekte-sekte yang ikut lenyep. Hanya bet hillel yang eksis. Eksistensi bet hillel nantinya akan berpengaruh terhadap keputusan-keputusan bagi hokum Yahudi dalam misynah yang mana menjadi fondasi dari Talmud. Bagaimanapun, Gamaliel memiliki pengaruh yang sangat besar secara raligius-politis. Hal ini dapat kita mengerti berkaitan dengan pengaruh Gamaliel pada masa pelayanan rasul-rasul Kristus seperti yang dicatat oleh Lukas dalam Kisah Para Rasul 5:34-38.

Paulus menyuruh keluar orang-orang (kemungkinan besar, orang-orang yang disuruh keluar adalah orang-orang yang hadir untuk menyaksikan jalannya pengadilan). Sesudah itu ia berkata "hai pria-pria Israel, berilah pertimbangan yang benar...". Mengingat posisi Gamaliel dalam masyarakat Yahudi, ia adalah seorang ahli Taurat - nomodidaskalos ${ }^{66}$. Robertson's Word Pictures Commentary "but there is no evidence of either position. Besides, he appears here as a loyal Pharisee and "a doctor of the law". ${ }^{67}$ Kemungkinan besar Yesus bertemu dengan Gamaliel di bait Allah ke ia datang bersama kedua orang tuanya (Luk. 2:47); juga tampil sebagai kritikus ketika Yesus melayani (Luk. $5: 17)$.

Dasar pertimbangan Gamaliel adalah berdasarkan kejadian-kejadian yang secara factual pernah terjadi dimana ada sekte-sekte yang melalukan hal serupa namun ahkhirnya lenyap. Atas dasar itulah, Gamaliel berkata kepada

${ }^{64}$ Raban adalah gelar tertinggi

65 Gamaliel atau Gamaliel I adalah seorang guru atau Rabi Yahudi pada zaman dahulu yang sangat terkemuka dan sangat disegani di antara tiga aliran Yahudi, yaitu Farisi, Saduki dan Essen. Pemikirannya turut memberikan kontribusi bagi terbentuknya cara hidup orangorang Yahudi pada akhir abad pertama hingga sekarang pada abad ke-21. Gamaliel juga adalah guru Rasul Paulus.

${ }_{66}$ Nomodidaskalos artinya a teacher of the law = ahli hokum Taurat

${ }^{67}$ Robertson's, Word Picture In the e-Sword 
laki-laki/pria-pria (kemungkinan petinggi-petinggi dalam Mahkamah Agama) untuk membuat suatu pertumbangan yang logis. Gamaliel mengungkapkan hipotesisnya berkaitan dengan kasus tersebut "sebab jika tidak, kamu tidak melenyapkan mereka melainkan melawan Allah". Tesisnya adalah "hal sekte/gerakan keagamaan yang berasal dari manusia akan lenyap sebaliknya hal ajaran yang berasal dari Allah akan tetap eksis. Tetapi jika dari Tuhan, kamu tidak mempunyai kekuatan untuk menghancurkan mereka.

Tetapi seorang Farisi dalam Mahkamah Agama itu, yang bernama Gamaliel, seorang ahli Taurat yang sangat dihormati seluruh orang banyak, bangkit dan meminta, supaya orang-orang itu disuruh keluar sebentar. Sesudah itu ia berkata kepada sidang: "Hai orang-orang Israel, pertimbangkanlah baikbaik, apa yang hendak kamu perbuat terhadap orang-orang ini! Sebab dahulu telah muncul si Teudas, yang mengaku dirinya seorang istimewa dan ia mempunyai kira-kira empat ratus orang pengikut; tetapi ia dibunuh dan ceraiberailah seluruh pengikutnya dan lenyap. Sesudah dia, pada waktu pendaftaran penduduk, muncullah si Yudas, seorang Galilea. Ia menyeret banyak orang dalam pemberontakannya, tetapi ia juga tewas dan cerai-berailah seluruh pengikutnya. Karena itu aku berkata kepadamu: Janganlah bertindak terhadap orang-orang ini. Biarkanlah mereka, sebab jika maksud dan perbuatan mereka berasal dari manusia, tentu akan lenyap, tetapi kalau berasal dari Allah, kamu tidak akan dapat melenyapkan orang-orang ini; mungkin ternyata juga nanti, bahwa kamu melawan Allah." Nasihat itu diterima (Kis. 5:34-39).

Keliberalan Gamaliel terlihat dalam pandangannya terhadap ajaran Yesus yang disebarluaskan melalui murid-murid-Nya. Ia dikenal karena sikapnya yang lebih toleran dan liberal dalam keputusannya dalam segi hukum keagamaan.

Sekolah yang ada dibawah asuhan Gamaliel merupakan salah satu sekolah terpandang. Hillel mengembangkan suatu ajaran agama Yahudi yang maju dan liberal bila dibandingkan dengan Syammai. Misalnya, ia mengajarkan bahwa seorang laki-laki dapat menceraikan isterinya jikalau istrinya tidak menyenangkan dalam hal apapun juga. Tetapi Syammai memberi pengecualian, 
hanya legal bila terjadi dosa moral yang berat. Ajaran Hillel ini, oleh sebagian orang dipandang sebagai dasar dan acuan Yesus tentang perceraian - Markus 10:1-12. Atau tentang penginjilan, Syammai berpandangan bahwa orang non Yahudi tidak memiliki tempat dalam rencana Allah, sebaliknya Hillel tidak demikian.

Paulus sangat fanatik terhadap agama Yahudi. Bahkan dari pengakuannya, ia sering menganiaya orang-orang Kristen bahka membunuh orang-orang kudus. Di hadapan raja Agripa, Paulus bersaksi bahwa "Hal itu kulakukan juga di Yerusalem. Aku bukan saja telah memasukkan banyak orang kudus ke dalam penjara, setelah aku memperoleh kuasa dari imam-imam kepala, tetapi aku juga setuju, jika mereka dihukum mati. Dalam rumah-rumah ibadat aku sering menyiksa mereka dan memaksanya untuk menyangkal imannya dan dalam amarah yang meluap-luap aku mengejar mereka, bahkan sampai ke kota-kota asing - Kisah para Rasul 26:10-11."

Paulus pra perjumpaan adalah Paulus yang masih dalam perspektif religiositas Yudaisme yang mana ia sendiri memandang hukum taurat sebagai yang dibuat manusia (Rom. 10:1-4). Bagi Paulus, pengalaman Damsyik merupakan suatu pengalaman batin yang bersumber dari wahyu Allah sendiri.

Paulus sendiri memberi kesaksian bahwa ia sangat rajin memelihara adat istiadat nenek moyang, ia adalah seorang Yahudi dari golongan Farisi - ini religiositas lama Paulus. Perjumpaan dengan Kristus merupakan peralihan dari religiositas lama kepada yang baru. Ia tidak lagi berada dibawah pengawasan hukum taurat melainkan dibawah hukum Kristus (Gal. 3:23-24). Sebelum pertobatan Paulus, Paulus digerakan oleh semangat hukum taurat namun setelah itu, ia lebih digerakan oleh semangat Roh Kudus yang bermula dari perjumpaan dan juga seperti ungkapan pokok yan boleh kita sebut mottonya "bagiku hidup adalah Kristus - Filipi 1:21 dan "Kristus hidup dalam aku Galatia 2:20".

Salah satu anti tesis Paulus tentang hukum taurat adalah tesis tentang pembenaran. Tesis Paulus tentang pembenaran adalah bahwa hukum taurat itu 
penuntun (Gal. 3:23,24) dan bahwa orang yang melakukan hukum taurat-lah yang akan dibenarkan (Rom. 2:13). Di Roma 3:20, Paulus menghadirkan anti tesis tentang hukum taurat bahwa tidak seorangpun yang dibenarkan karena melakukan hukum taurat justru karena hukum taurat orang mengenal dosa. Ini merupakan anti tesis Paulus untuk menghadirkan tesis baru soal pembenaran, yakni iman (Rom. 3:21-31; 5:1,2). Setelah itu, untuk membuktikan tesisnya, Paulus menghadirkan Abraham dan Daud sebagai tokoh sentral dalam Yudaisme, yang mana Abraham dipandang sebagai bapak segala orang beriman dan dibenarkan karena iman (Rom. 4:1-25); diulang kembali di Galatia 3.

Fenomena pada masa pra perjumpaan adalah

1) Berlatar belakang bangsa Yahudi (band. Kis. 22:3)

2) Menempuh pendidikan di bawah maha guru Gamaliel

3) Antusias untuk membunuh murid-murid Tuhan (band. Kis. 9:1)

Perhatikanlah, dari ketiga fenomena yang terdata di atas, maka ketiga fenomen di atas saling terkait. Antara fenomen pertama dan kedua membentuk sudut pandang dan kepribadian Paulus. Ia telah mempersiapkan diri dari segi agama (pengetahuan) dan mendapat dukungan dari pihak-pihak pemegang otoritas dalam agama Yahudi karena keyahudiannya. Dua fenomen pertama menjadi pemicu fenomen ketiga, yakni "berkobar-kobar hati Saulus untuk mengancam dan membunuh murid-murid Tuhan”. Untuk mendapatkan pengesahan tindakan sebagai tindakan yang legal maka ia meminta surat kuasa kepada Imam Besar.

Dari fenomena-fenomena yang ada maka tergambar bahwa "fenomena utama (membunuh murid-murid Tuhan) tidak muncul sendiri melainkan ditunjang oleh fenomen-fenomen lainnya (latar belakang keyahudiannya dan pendidikannya). 


\section{Perjumpaan Pneumatik dengan Kristus: Titik Kulminasi Religiusitas}

Kisah para Rasul 9:3-9 menyajikan fenomena perjumpaan Paulus dengan Kristus. Mengamati kisah perjumpaan Paulus, dalam pra anggapan saya, sangat kecil kemungkinannya Paulus bertobat melalui "perdebatan" teologis. Pra anggapan ini didasarkan pada argumentasi Paulus saat memberikan pledoi di hadapan raja Agripa (Kis. pasal 26) dan ucapan Festus kepada Paulus "engkau gila, Paulus! Ilmumu yang banyak itu membuat engkau gila (Kis. 26:24).

Fenomena kepribadian dan keagamaan Paulus pra perjumpaan mengarahkan kita untuk melihat fenomen lain pasca perjumpaan sebagai kemungkinan lain yang memungkinkan dia untuk bertobat yakni "perjumpaan dengan Kristus". Jika ini yang terjadi maka tidak ada perdebatan. Pandangan ini saya dasarkan pada kesaksian Paulus saat berada di hadapan raja Agripa. "Sebab itu, ya raja Agripa, kepada penglihatan yang dari sorga itu tidak pernah aku tidak taat (Kis. 26:19).

Perhatikanlah, fenomena perjumpaan Paulus memunculkan fenomena bawaan seperti berikut ini:

1) Cahaya memancar dari langit mengelilingi dia (terjadi secara tiba-tiba). Kisah para Rasul 9:3

2) Rebah ke tanah dan mendengar suara: Saulus, Saulus, mengapakah engkau menganiaya Aku?. Kisah Para Rasul 9:4, Saulus menjawab: siapakah Engkau, Tuhan? Katanya: Akulah Yesus yang kau aniaya itu. Bandingkan Kisah para Rasul 26:12-18

3) Tiga hari lamanya ia tidak dapat melihat

Dari fenomena-fenomena di atas tersaji "dialog" Paulus dengan seseorang yang teridentifikasi sebagai Yesus saat Saulus menjawab, siapakah engkau, Tuhan?. Dan Saulus dijawab: Akulah Yesus yang kau aniaya.

Dari fenomena ini, tertangkap fakta-fakta yang dapat ditelaah lebih jauh: 
1) Jika dibandingkan dengan kasus Samuel terpanggil (1 Sam. 3:1-14). Dalam kisah Samuel, Samuel tidak tahu siapakah yang memanggilnya. Namun ia menanyakannya kepada imam Eli. Di kasus Samuel pun, imam Eli tidak langsung menyimpulkan bahwa yang memanggil adalah Tuhan. Barulah ketiga kalinya Eli mengerti dan memastikan kepada Samuel bahwa apabila Ia memanggil engkau, katakanlah: berbicaralah Tuhan sebab hambamu ini mendengar (1 Sam. 3:8). Kasus Paulus, Paulus menjawab, siapakah engkau Tuhan.

2) Fenomena Paulus rebah ke tanah dan tiga hari lamanya tidak melihat merupakan fenomena temprorer personal. Artinya hanya pada waktu itu dan hanya kepada Paulus dan tidak dapat digeneralisasikan untuk konteks kini.

Dari fenomena perjumpaan ini, kita melepaskan diri dari fenomena yang muncul saat itu untuk maju pada fenomena bawaan (boleh kita katakan sebab yang diakibatkan) yakni pasca perjumpaan. Bagaimana tanggpan kita terhadap fenomena yang muncul di Kisah Para Rasul 9:3-9 (rebah, cahaya yang memancar dari langit, buta). Sebaiknya kita melepaskan fenomena ini sebab inti terdalamnya tidak ada di sana. Ini hanya penuntun untuk mengerti dan mengungkap yang lebih mendalam. Jika kita hanya sampai di sini saja maka kita cenderung menyimpulkan bahwa "kalau orang berjumpa dengan Tuhan harus rebah, ada cahaya, Tuhan bicara.

Marilah kita beralih kepada fenomena bawaannya. Perhatikan Kisah pada Rasul 26:19, "sebab itu ya Agripa, kepada penglihatan yang dari sorga itu tidak pernah aku tidak taat". Kesaksian Paulus ini, ia mengenang kembali perjumpaan itu (sejarah perjumpaannya. Namun ia tidak 'melongo' dan tinggal diam atau jumawa dalam perjumpaan itu). Dengan perkataan lain, perjumpaan itu menjadi alasan baginya memberitakan Injil. Fenomena pelayanan Paulus yang ia tunjukkan melalui kesungguhannya memberitakan Injil, bersedia menderita bagi Kristus (bagiku hidup adalah bagi Kristus dan mati adalah keuntungan), bersedia meninggalkan hal-hal yang dahulunya berarti namun saat berjumpa Yesus menjadi tidak berarti. 
Pengalaman Kristen dalam kelahiran baru adalah pengalaman langsung dengan Allah sendiri - 2 Korintus 5:7. Perjumpaan antara orang berdosa dengan Kristus akan mengubah perspektif si berdosa dari jalan kematian kepada realitas kehidupan kekal; perjumpaan Paulus dengan Kristus di Damsyik mengubah perspektif Paulus. Paca perjumpaan Damsyik membawa perubahan dalam paradigma Paulus.

Pengalaman ini "self authenticating (membuktikan sendiri akan keasliannya). Tak perlu bukti tambahan. Pengalaman ini mengatakan bahwa Allah yang benar dikenal hanya bila Ia mengambil inisiatif dan menyatakan diri-Nya kepada manusia (Mat. 11:27)... kebenaran ditemukan hanya bila manusia menanggapi inisiatif Allah. ${ }^{68}$

Mungkin kita bertanya, bagaimana pandangan Paulus tentang kebenaran pra kisah Damsyik? Kemungkinan besar hanya sebatas syariat. Pasca kisah Damsyik, Paulus berada dalam perspektif yang baru. Ia dicelikkan melalui pengalaman tersebut sehingga ia dapat melihat nilai-nilai kebenaran Allah yang hidup di dalamnya. Datang melalui ketaatan akan hukum taurat. Nilai-nilai kebenaran itu datang dari atas melalui suatu perjumpaan pribadi dan bukan dari bawah. Berbicara soal mistisisme di sini, bukan berarti pengalaman menggantikan Alkitab sebagai sumber utama epistemologi religius.

Tepat apa yang dikatakan Heath bahwa "orang Kristen tidak cukup hanya menunjukkan ayat-ayat yang membawa keselamatan kepada unbeliever, tetapi orang berdosa itu perlu bertobat (menanggapi kesaksian Roh Kudus atas firman itu). Pengalaman tidak menggantikan posisi otoritas, tetapi melengkapi posisi otoritas.

Perjumpaan di Damsyik menjadi titik kulminasi atau puncak karier Paulus dalam agama lamanya dan titik perangkat keagamaan baru Paulus. Sebab para perjumpaan Damsyik, Paulus masih dalam keagmaan Yahudi yang ketat, kaku dan keras. Namun pascaperjumpaan itu, Paulus memasuki tahapan 2007).

68 Stanley Heath, Filsafat Apologetika. Catatan Kuliah (Surakarta: STT Berita Hidup, 
baru dalam keberagamaannya. Ia memasuki dimensi baru dalam perjalanan religiositasnya dan rupa-rupanya perjumpaan tersebut menjadi titik berangkat ajaran dan teologia Paulus. Di mana bukan lagi hukum-hukum agama Yahudi yang kaku dan keras menjadi titik tolak melainkan Yesus dan ajaran-Nya menjadi titik berangkatnya. Hal ini dapat dijumpai dalam surat-suratnya; Yesus menjadi pusat berita dan ajarannya, bukan legalitas dan yuridis Yahudi yang utama.

Dari penerapan metode fenomenologi, setiap fenomen yang kita tangkap, kita harus menyaringnya (eidetic) sehingga kita dapat memilah dan memisahkan mana fenomena utama dan mana yang bukan fenomena. Kita dapat menemukan berbagai fenomena dari objek yang kita amati namun tidak semuanya dapat mengungkap tentang inti terdalam dari objek.

Seperti dalam kasus perjumpaan Paulus dengan Yesus, kita dapat menemukan gejala-gejala (rebah, cahaya yang memancar, tidak dapat melihat) namun tidak dapat mengungkap sesuatu dan kita tidak dapat menemukan makna hakiki. Kita harus membuang fenomena-fenomena yang tidak utama namun mengambil yang utama sehingga kita dapat memperoleh makna.

Bahwa orang yang berjumpa dengan Kristus harus mengalami pertobatan. Pertobatan dapat diartikan sebagai perubahan, baik perubahan paradigma, prinsip hidup, konsep diri, prinsip pelayanan, dll. Selanjutnya pemahaman yang benar tentang keimanan dapat membawa umat ke dalam perubahan sikap hidup atau yang dapat mewujud dalam pola laku keseharian di masyarakat seperti yang diteladankan Rasul Paulus. Bahwa tidak ada gap antara pemahaman dan pola laku keseharian orang percaya dalam masyarakat. 


\section{BAB LIMA}

\section{PLURALITAS KEYAKINAN DALAM KONTEKS KEINDONESIAAN69}

\section{A. Manusia dan Agama}

Agama, ${ }^{70}$ merupakan istilah yang kompleks dalam arti. Istilah yang sering mengacu pada istilah agama adalah religio. Kata religio sendiri, sulit untuk melacak maknanya. Kata ini sering dihubungkan, dalam makna, dengan kata religare, artinya mengikat kembali. Atau kata "relegare yang berarti terus menerus berpaling kepada sesuatu'.71 Arti relegare, berpaling terus-menerus berpaling kepada sesuatu, sesungguhnya selalu dalam tahap proses yang kontinua bukan distkontinua. Di sinilah manusia mamahami diri sebagai yang lemah dan sesuatu, yang kepadanya manusia berpaling dipandang sebagai yang memiliki kekuatan supra. "Sesuatu" dalam makna relegare, jangan dipikirkan melulu sebagai objek melainkan sebagai "subjek".

Dalam sejarahnya, agama muncul dengan empat factor lahiriah yang menandainya, yakni ritual, emosi, kesaksian iman dan pertanggungjawaban rasional (pikirkan bahwa, teologia sistematika merupakan bentuk pertanggungjawaban rasional). Atau dogma - ajaran, ibadat - kultus, moral etika, lembaga - organisasi.

Whitehead memberi catatan tentang agama bahwa "agama rasional yang kesaksian iman dan upacara-upacaranya sudah direorganisasi sedemikian rupa dengan maksud menjadikannya elemen sentral dalam menata hidup secara

69 Bagian ini merupakan tulisan saya yang sebelumnya diterbitkan di Jurnal Stulos STT Bandung. Noh Ibrahim Boiliu, "Manusia dan Pluralisme Keyakinan di Indonesia”, Jurnal Stulos 10, no. 1, (2011), 53-71.

70 Bandingkan dengan, Wilfred Smith, Memburu Makna Agama (Bandung: Mizan, 2004).

71 Agus M. Hardjana, Religiositas, Agama dan Spiritualitas (Yogyakarta: Kanisius, 2009), 29. 
koheren - penataan itu secara koheren, baik sewaktu menjernihkan pemikiran maupun sewaktu mengarahkan perilaku kepada suatu kesatuan perspektif yang memungkinkan persetujuan etis".72 Secara tidaklangsung, Whitehead, mengiyakan bahwa agama bergerak secara evolutif, dari tahap primitive hingga universal.

Memang demikian, karena dalam bukunya Religion in the Making, Whitehead mengkritik Emile Durkheim. ${ }^{73}$ Durkheim memandang agama sebagai suatu "fenomena sosial"sedangkan Whitehead memandangnya sebagai salah satu tahap perkembangan religiositas.

Dalam agama rasional, bahwa tidak hanya emosi (religiositas), ritual, dan upacara-upacara yang memainkan peran penting. Melainkan "rasio" juga ikut andil di dalamnya. Di sini Wheathead memberi tempat bagi rasio. Maksudnya adalah sewaktu-waktu, kita dapat dengan penuh kesadaran memeriksa kembali aspek-aspek agama temasuk ajarannya.

Alfred North Whitehead, dalam makna luas dari agama, berkata bahwa "dari sudut doktrin, agama dapat didefinisikan sebagai sistema kebenarankebenaran umum yang memiliki kekuatan untuk membentuk karakter, asalkan kebenaran-kebenaran itu dianut secara tulus dan sungguh-sungguh dihayati". ${ }^{74}$ Dari definisi agama yang diberikan Whitehead, Whitehead memberi catatan bahwa kebenaran-kebenaran dalam agama dapat membentuk karakter, dengan syarat kebenaran-kebenaran dihayati oleh umat.

Artinya, kebenaran dalam agama tidak menjadi persoalan, yang menjadi persoalan adalah para pemeluk. Dalam konteks ini, tentu kita memahami dalam konsep umum kebenaran agama-agama.

Sebuah catatan kritis bagi kita umat Kristen, mungkin kita menganggap atau meyakini bahwa, Kristus adalah satu-satunya kebenaran. Ya, itu benar,

${ }^{72}$ Alfred North Whitehead, Mencari Tuhan Sepanjang Zaman: Dari Agama- Kesukuan Hingga Agama Universal. Terj. Alois Agus Nugroho (Bandung, Mizan, 2009), 18.

${ }^{73}$ Catatan yang diberikan oleh Alois Agus Nugroho.

${ }^{74}$ Alfred North Whitehead, Mencari Tuhan Sepanjang Zaman, 4. 
tetapi kebenaran dalam Kristus, hanyalah tidak bermakna, ketika kita sebagai umat tidak membawanya dalam penghayatan. Maka kebenaran Kristus, tak ada bedanya dengan keyakinan lain, yang oleh kita, dianggap tidak benar (sesat).

Magnis Suseno berkata "tidak ada masyarakat di dunia ini yang tidak beragama".75 Artinya, sebagian besar menganut salah satu agama besar. Namun, agama-agama besar justru muncul pada masa manusia telah mencapai tingkat kebudayaan yang maju atau boleh kita sebut agama-agama modern. Bukan berarti masyarakat sebelumnya tidak beragama. Mereka telah beragama meskipun mungkin kita sebut masih dalam taraf primitif (arti ini tidak hanya sebatas kuno atau ketinggalan zaman).

Diberbagai belahan dunia telah ditemuakan bangunan-angunan, lukisanlukisan, cerita-cerita kuno, mitos-mitos dan ritus-ritus yang melukiskan tentang penghormatan dan penyembahan suatu masyarakat kepada The holy one. Tidak dalam ajaran yang tersusun secara sistematis. Sedangkan Alfred dalam bukunya The Divine Succession A Science Of Gods Old And New berkata bahwa agama adalah aktifitas manusia yang otonom bahkan merupakan suatu fakta eksistensi - "Religion is an autonomous human activity, a fact of existence". ${ }^{76}$

Dalam kepercayaan-kepercayaan primitive atau suku harus kita terima bahwa mereka takut, gentar (tremendum) namun yang menggetarkan hatinya penuh emosi (fascinans). Mareka melihat-Nya sebagai personalisasi dari yang numinous dibalik apa yang terjadi.

\section{B. Kekristenan dan Pluralitas Keyakinan di Indonesia}

Ultim, demikianlah istilah yang berkaitan dengan hal yang terakhir. Akhir dari realitas manusia sebagai manusia adalah kematian. Kematian merupakan ultim dari manusia. Dan memanglah demikian ditemui sebagai argumentasi dalam agama-agama. Namun kematian manakah yang menjadi

\footnotetext{
75 Dapat membacanya dalam bukunya Frans Magnis Suzeno, Menalar Tuhan, (Yogyakarta: Kanisius, 2007).

76 Alfred de Grazia, The Divine Succession: A Science Of Gods Old And New (New York: Multiprint Company, 1983), 4.
} 
ultim manusia apakah merupakan ultim yang berakhir atau sebagai proses menuju yang tak berakhir?

Mengapa orang berpikir tentang suatu "situasi" yang belum pasti secara rasional namun telah terlampau percaya "bahwa memang akan terjandi demikian”. Seolah-olah hal atau kejadian sudah ada didepan mata atau sedang dirasa. Yang percaya bahwa hal atau suatu kejadian akan terjadi seperti yang dipercayai kita sebut golongan orang spiritualis sedangkan yang mempertanyakan dan mempersoalkan akan apa yang terjadi kelak dan mencari jawabannya diluar "agama" kita sebut "rasionalis non-agamis". Tetapi ada juga yang berdiri di atas tiang "agama" dan memandang ke depan mengenai hal-hal yang akan terjadi setelah kematian atau nasib dunia yang akan datang boleh kita sebut golongan "raionalis agamis atau rasionalis spiritualis". Manusia oleh beberapa orang disebut sebagai Das Problema Des Menschen (Buber).

Manusia? Sebagai Das Problema Des Menschen dan sebagai animal rationale/ logos anthropos, manusia mempertanyakan tentang Tuhan, kehidupan, dan sesudah kehidupan. Dalam lingkup manusia sebagai problema (kata Buber), manusia kemudian merefleksi diri dan menemukan diri sebagai makhluk yang bergantung pada ratio sui (peletak dasar) dan causa sui (penyebab utama) atau Causa Prima (penyebab tunggal). Di dalam merefleksi diri, manusia sadar akan diri dan eksistensinya tentang suatu "situasi" yakni "kehidupan sesudah kematian". Atau hal-hal apa saja yang akan terjadi kelak. Manusia, sedang berjalan menuju suatu kehidupan yang to apeiron ( Anaximadros) atau berjalan dalam kenyataan menuju kosmos noe'tos (dunia yang tidak kelihatan) namun real ketika mengalami thanatos.

\section{Pluralisme Sebagai Suatu Perubahan}

Pluralisme muncul sebagai suatu bentuk perubahan baik perubahan budaya maupun paradigma. C.A. van Peursen dalam bukunya "Strategi Kebudayaan" mencatat tiga tahap perubahan, yakni alam pikiran mitis, 
ontologis dan fungsionil. ${ }^{77}$ Ketiga tahap ini dalam sudut pandang filsafat (budaya) memberi kontribusi pemikiran dan perenungan sebagai jalan ke pluralisme dan pluralitas agama.

Di alam pikiran mitis ${ }^{78}$, manusia menyusun suatu strategi, mengatur hubungan-hubungan antara daya-daya kekuatan alam dan manusia. ${ }^{79}$ Sebab mitos memainkan peran penting dalam masyarakat primitif dan berfungsi untuk "menyadarkan manusia bahwa ada kekuatan gaib, membantu manusia menghayati daya-daya tersebut sebagai suatu kekuatan yang mempengaruhi dan menguasai sukunya."80 Artinya mitos menampakan kekuatan-kekuatan, menjamin kekinian dan memberi pengetahuan tentang dunia dan memberi weltanschauung. Prinsipnya adalah "ada sesuatu" yang mana dapat di "raba" melalui lambang-lambang yang oleh M. Eliade, lambang (pohon kehidupan, air tirta, topeng, dll) mengarah ke kekuatan yang ada di atas atau transenden sehingga "sesuatu" itu menimbulkan rasa hormat dan rasa takut penuh kegentaran. Mitos tidak berfungsi untuk memberi informasi.

\section{Dari Pikiran Mitis Hingga Fungsional}

Dari alam pikiran mitis yang ditandai dengan rasa takut terhadap dayadaya yang manusia belum mengambil distansi terhadap segala sesuatu. Peralihan dari mitis ke ontologis ditandai dengan pengambilan distansi terhadap segala sesuatu yang mengitarinya. Dengan pengambilan distansi, manusia keluar dari kungkungan mitos dan mempertanyakan keberadaan "daya-daya" yang menggerakan manusia dan alam, tujuannya adalah untuk mengerti.

Tradisi Yunani klasik (kuno) peralihan dari mitis ke ontologis sangat penting, di mulia dari ketertakjuban akan alama raya (para filsuf alam) yang

77 C. A. van Peursen, Strategi Kebudayaan (Yogyakarta: Kanisius, 2001), 34-109. Tentang tema-tema tersebut dapat di baca dari halaman 34-109.

${ }^{78}$ Mitis mengarah pada sifat dari mitos yang berarti cerita yang memberikan perdoman dan arah tertentu kepada sekelompok orang yang dapat dturunkan melalui metode cerita atau pementasan tari atau wayang.

79 Ibid., 36.

${ }^{80}$ Ibid. 
mencari arkhe dari setiap realits dan peralihan tersebut mempengaruhi masyarakat dalam wadah ilmu pengetahua, baik Barat, Timur, Utara maupun Selatan. Dalam perkembangan selanjutnya, Plato, misalnya dengan konsep filosofis "ide-ide".

Di kemudian hari di dunia Barat (Eropa) kembali mempertanyakan hakekat segala sesuatu, yakni pertanyaan tentang "Ada-nya", tak pelak Ada-nya Tuhan pun dipertanyakan, apakah monis ataukah pluralis? Pertanyaanpertanyaan tersebut, sebagai jalan untuk meretas pengetahuan tentang Ada-nya Tuhan.

Alam "pikir" ontologis merupakan suatu bentuk titik terang di mana manusia mencoba mengurai "mitis" yang oleh Max Mueller di sebut "bayangan gelap"81 dalam konteks bahasa kebudayaan. Manusia tidak hanya hendak mengetahuai tentang "Ada" sesuatu melainkan sesuatu itu dipertanyakan, yakni "apa"nya para dewa yang menyangkut kodrat dan keberadaan para dewa. Pertanyan tentang "apa"nya para dewa bukan dalam segi "arogansi" manusia melainkan pertanyaan yang disertai rasa hormat. Van Peursen lalu menegaskan bahwa "hakekat kodrat para dewa disimpulkan melalui jalan argumentasi, sambil terus memeras otak dan ilmu ini pada jaman klasik pun dinamakan theologia". ${ }^{2}$ Dengan mempersoalkan "apa"nya merupakan hal metafisis yang problematik. Sekali lagi van Peursen mengingatkan bahwa dalam mempersoalkan hakekat atau apa-nya para dewa, telah menimbulkan, “...teoriteori theologis yang berbelit-belit. Istilah-istilah yang dipergunakan jelas menonjolkan apa-nya, misalnya "kodrat" (dalam Kristus diri Kristus terdapat dua kodrat) dan "hakekat" (dalam Trinitas terdapat tiga pribadi dalam satu hakekat. Dalam filsafat Tuhan disebut Pengada Tertinggi, yang meliputi segala sesuatu, sebab pertama, dan dasar dunia"83.

Catatan bagi "hal besar" yang hendak dibahas, yakni pluralitas agama (teologia agama-agama) maka hal tersebut masuk dalam ranah filsafat agama

\footnotetext{
${ }^{81}$ Lorens Bagus, Kamus Filsafat, 661.

82 C.A. van Peursen, Strategi Kebudayaan, 36.

83 Ibid.
} 
dan dan filsafat ketuhanan. Filsafat ketuhanan, istilah van Peursen "filsafat Tuhan" memandang Tuhan sebagai Pengada Tertinggi, Causa Prima atau Penggerak yang Tak Tergerakan. Hal ini nantinya lambat laun akan ditemukan sebagai titik sentral dari pluralisme agama - melepas setiap keunikan agama atau sebutan-sebutan, simbol-simbol masing-masing agama (ada reduksi) sehingga hanya memandang pada Sang Pengada Tertinggi.

Kembali pada tiga alam pikir yang sedang dibahas. Kini kita masuk pada tahap fungsionil. Berkaitan dengan istilah ini, van Peursen memang menegaskan bahwa kata ini digunakan khusus untuk kebudayaan modern.

Tahap ontologi merupakan tahap pembebasan dari magi ${ }^{84}$ dan tahapan fungsionil membebaskan dari substansialisme - Ada. Aspek dari pemikiran fungsionil adalah bagaimana memberi dasar kepada masa kini. Di tahap mitis, daya-daya adikodrati menjamin suksesnya perbuatan-perbuatan namun di tahap fungsionil hal-hal tersebut tidak dihiraukan. Maka masa kini setiap hal harus dipertanggungjawabkan dan harus memberi manfaat. Baik bidang apa saja termasuk teologi erat kaitannya dengan aspek fungsionil yakni apakah memberi arti atau tidak. "Dulu kata-kata seperti "Tuhan", "kepercayaan", "kesusilaan", "kebenaran", "keindahan" tidak perlu lagi dijelaskan; arti dan daya untuk meyakinkan dengan sendirinya sudah terkandung dalam kata-kata tersebut. Kini kepastian-kepastian serupa rupanya lenyap ... isi kata-kata itu perlu dibuktikan nilainya bagi kita, ... lepas dari diri kita sendiri - "apa”nya tidak diutamakan lagi, melainkan caranya bagaimana arti itu lambat laun nampak dalam hidup kita sehati-hari - bagaimana-nya". ${ }^{5}$

\section{E. Manusia dan Pluralitas Keyakinan}

Dalam kaitannya dengan pluralisme agama, pemikiran ini mengetengahkan suatu prinsip bahwa "apa"nya termasuk teologi tidak diutamakan melainkan bagaimana refleksi (teologis) nampak dalam kehidupan

${ }^{84}$ Ibid.

${ }^{85}$ Ibid. 
sehari-hari. Artinya hal eksklusivitas tidak lagi menjadi hal utama melainkan kehadiran masyarakat (beragama) memberi dampak. Penghalang-penghalang teologis disingkirkan.

Perubahan budaya (antropologi budaya) dimaksud di dalamnya terdapat pula perubahan kepercayaan (antropologi agama). Agama tidak hanya dilihat pada tataran mitisnya, ontologisnya melainkan juga dalam tataran fungsionialnya, yakni bagaimana agama dan penganutnya memberi dampak bagi bumi yang didiami yang seyogyanya sangat plural dalam budaya dan keyakinan.

Tema pluralisme agama muncul seiring dengan problem pluralitas masyarakat dan juga pluralitas kepercayaan atau agama di bumi seperti yang nyatakan dalam buku Satu Bumi Banyak Agama karangan Paul Knitter. Di tingkat pluralitas masyarakat dan dengan berkembangnya masyarakat, maka dalam suatu kelompok masyarkat yang dahulunya "homogen" kini berangsur tidak homogen lagi melainkan "heterogen". Hal ini disebabkan oleh derasnya arus pasar bebas dan turisme sehingga dalam masyarakat yang heterogen (dari berbagai suku dan ras) maka heterogen pula kepercayaan atau agama. Hal ini ditegaskan oleh Waolfhart Pannenberg dalam "Pluralisme Keagamaan dan Klaim Kebenaran yang Saling Bertentangan” bahwa pluralitas dan pergolakan agama merupakan akibat dari komunikasi modern dan pertukaran serta mobilitas antar-budaya ${ }^{86}$ dan terjadinya perubahan budaya atau culture change yang mana perubahan itu tidak terjadi secara mendadak dan siknifikan melainkan perlahan dan siknifikan.

Pluralitas atau kemajemukan agama merupakan faktor muncul pluralisme meski tidak menafik kenyataannya dalam alkitab. Fakta tentang keberagaman agama dan kemajemukannya adalah satu hal yang tidak bisa dipungkiri oleh siapapun juga. Dan secara otomatis tiap-tiap agamapun akan bersentuhan dengan agama-agama yang lain. Hans Kung seorang teolog katolik yang radikal dalam tulisan Pinnock mengemukakan,"Untuk pertama kali

${ }^{86}$ Gavin D'Costa Peny., Mempertimbangkan Kembali Keunikan Agama Kristen (Jakarta: BPK Gunung Mulia, 2002),167. 
dalam sejarah dunia adalah sesuatu yang mustahil bagi satu agama untuk eksis dalam isolasi yang sangat baik dan mengabaikan yang lain.” Kesadaran akan kemajemukan itu tidak hanya sampai pada tingkat mengalami keberadaan agama lain, tetapi juga dituntut untuk membangun hubungan yang baik dan toleransi yang lebih luas. Maka tak terhindarkan lagi seruanseruan untuk dialog dan membuka hubungan yang lebih luas mulai diperdengungkan.

\section{F. Kepelbagaian Keyakinan dalam Negara Pancasila}

Di Indonesia, secara defakto baik dalam tingkat masyarakat kecil (keluarga) maupun pada tingkat masyarakat luas, realitas fenomena pluralitas agama mudah ditemui. Contohnya, di salah satu gereja di daerah Kabupaten Grobogan - Jawa Tengah, terdapat sebuah keluarga yang berbeda-beda keyakinan (agama) dapat hidup rukun. Ayahnya berkeyakinan Muslim yang soleh sedangkan anaknya berkeyakinan Nasrani; di Jakarta, rekan saya, ayah dan ibunya berkeyakinan Kong $\mathrm{Hu} \mathrm{Cu}$ sedangkan anaknya berkeyakinan Nasrani, juga dapat hidup rukun.

Dari kedua contoh di atas, memang mereka hidup bersama dalam perbedaan. Namun masing-masing tetap berada pada posisi klaim keabsolutan, ke-eksklusivan maupun kefinalitas Tuhan dalam keyakinan masing-masing.

Berkaitan dengan heterogenitas keyakinan tadi, klaim keabsolutan, keeksklusivan maupun kefinalitas Tuhan dalam keyakinan masing-masing memang di satu sisi "sungguh indah" karena dalam satu keluarga dapat hidup rukun dalam kepelbagaian keyakinan" namun tidak menutup kemungkinan munculnya konflik atau "percikan-percikan api" sehubungan dengan heterogenitas keyakinan tadi. Bahkan mungkin tidak dalam tingkat keluarga melainkan tingkat masyarakat luas.

Klaim-klaim terkadang mengarah pada sikap radikalisme yang mana mudah digerakan dan melahirkan perang saudara yang bernuansa agama dan dapat ditunggangi kepentingan-kepentingan politis. Di samping de fakto, secara yuridis, Pancasila dan Undang-undang Dasar 1945 menjamin hak memeluk 
agama (meski tumpul dalam tataran praksis). Sila I, Ketuhanan Yang Maha Esa, menjadi dasar pemahaman manusia ber-Tuhan dalam keberagaman kepercayaan. Suatu pengakuan adanya Tuhan. Di sini Tuhan sebagai dasar penalaran moral. Maka harus mengiyakan pandangan Drijarkara bahwa Pancasila tidak bertentangan dengan Religi. Sebaliknya "menjadi dukungan pengakuan bagi religi yang dipahami tak terpisah dari Tuhan". ${ }^{87}$ Dasar yang diletakan di Sila I, "bukan dasar yang monis eksklusivistis melainkan plural inklusivistis. Artinya Pancasila menjamin keberadaan masing-masing agama sebagai agama pendatang di luar kepercayaa-kepercayaan primitif" 88 seperti bagan berikut:

87 Dalam pemahaman Drijarkara, Drijakara memahaminya sebagai potensi ke Religi. Bahkan Pancasila merupakan dukungan bagi Religi. Di celah itulah saya kemudian memahaminya sebagai suatu pengakuan adanya Tuhan.

88 Bukan terkebelakang dalam IPTEK melainkan masih melestarikan dan mempertahankan keyakinan-keyakinan tradisional. 


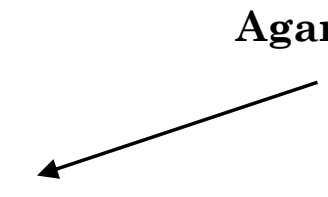

Pribumi

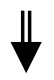

Tidak terpisahkan dari adat

dan budaya setempat

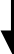

Non-pribumi

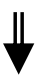

Dari luar:

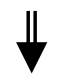

Agama suku atau keluarga Islam, Kristen, Hindu, Budha

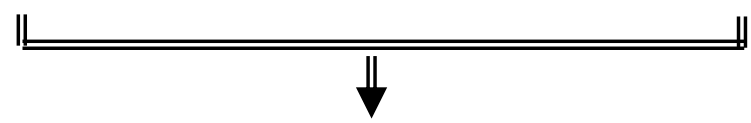

Berbeda dlm pelaksanaan ritual,upacara-upacara $\rightarrow$ fenomena

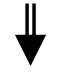

SATU DALAM HAKEKAT $\longrightarrow$ nomenon

Theis

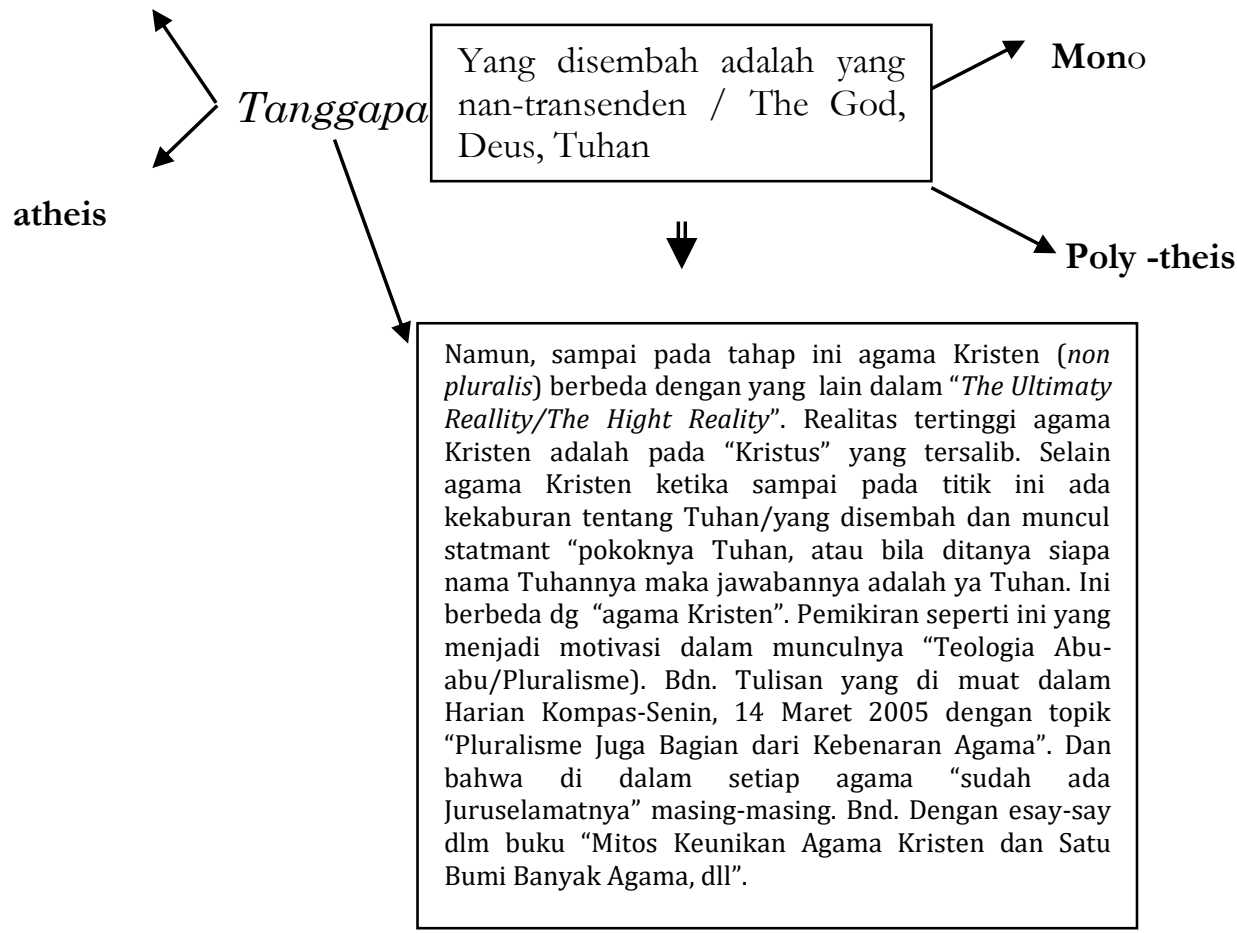


Sila I, Ketuhanan Yang Maha Esa, "menjadi dasar pemahaman manusia ber-Tuhan dalam keberagaman kepercayaan. Suatu pengakuan adanya Tuhan".89 Di sini Tuhan sebagai dasar penalaran moral. Maka harus mengiyakan pandangan Drijarkara bahwa Pancasila tidak bertentangan dengan Religi. Sebaliknya menjadi dukungan pengakuan bagi religi yang dipahami tak terpisah dari Tuhan.

Dasar yang diletakan di Sila I, "bukan dasar yang monis inklusivistis melainkan plural eksklusivistis. Artinya Negara tidak di dasar pada pemahaman kepercayaan tertentu. Sehingga terbuka bagi teori subordinansi" ${ }^{90}$ Teori ini boleh dikata sarat konflik, sebab salin mensubordinasi. Mungkin di negara - negara yang mengenal 'agama negara-negara agama' atau yang lazim disebut dengan 'state religion' dan 'religion state', tidak menjadi masalah.

Ketidaksetujuan berkaitan dengan asaz bangsa Indonesia. Indonesia memiliki lebih dari satu agama yang berasazkan Pancasila dan UUD 1945 sebagai dasar dan tolak ukur maka antara yang satu dengan yang lain tidak boleh disubordinasikan. Di sini, "negara tidak boleh memberikan pilihan kepada suatu agama atas pihak lainnya. Hal ini merupakan prinsip tentang tidak memihak. Prinsip tersebut tidak hanya mengatur tentang pendirian gereja-yang keberadaannya mungkin memunculkan argumentasi logis agar sesuai dengan prinsip kebebasan-tetapi juga melarang praktek-praktek demikian sebagai persyaratan yang sah suatu afiliasi agama tertentu sebagai suatu persyaratan bagi instansi-instansi umum". ${ }^{91}$

Artinya negara tidak boleh memihak pada salah satu agama yang pada akhirnya mengoyakan karpet demokrasi. Hal senada juga diungkapkan oleh Rober Audi bahwa "dominasi kekuasaan dalam kelompok-kelompok suatu

89Dalam pemahaman Drijarkara, Drijakara memahaminya sebagai potensi ke Religi. Bahkan Pancasila merupakan dukungan bagi Religi. Di celah itulah saya kemudian memahaminya sebagai suatu pengakuan adanya Tuhan.

${ }^{90}$ Departemen Agama RI, Bingkai Teologi; Kerukunan Hidup Umat Beragama Menurut Pandangan (Kristen) Protestan) (Jakarta: Departemen Agama RI, 1997).

${ }^{91}$ Robert Audi, Agama dan Nalar Sekuler dalam masyarakat Liberal (Yokyakarta: UII Pres, 2002), 49. 
agama dengan mudah merusak demokrasi". ${ }^{92}$ Sebab negara Pancasila bukan state religion atau religion state.

Sedangkan Sila II-V menjadi landasan pemahaman bagi kehidupan berkemanusiaan, berpersatuan, berkerakyatan dan berkeadilan. Ini harus dipahami dengan baik oleh manusia realitas Ada untuk dirinya dan ada bersama. Dalam ada bersama itulah, manusia mengusahakan dirinya dan yang lain selalu dalam ber-perikemanusiaan, ber-perikeadilan, ber-kerakyatan dan ber-keadilan social (social selalu dalam homo homini sosius bukan homini lupus) yang diikat oleh cinta kasih.Di situ, manusia memandang sesamanya sebagai Aku-Engkau bukan Aku-Itu dan juga bukan Aku-Dia (salah satu pemikiran Martin Buber).

\section{G. Pancasila yang Hirarkis Piramidal ${ }^{93}$}

Gambar di bawah ini menunjukkan suatu pemikiran terhadap pancasila sebagai pancasila yang hirarkis pyramidal. Alur pikirnya adalah memahami sila-sila pancasila sebagai satu kesatuan yang saling mendasari.

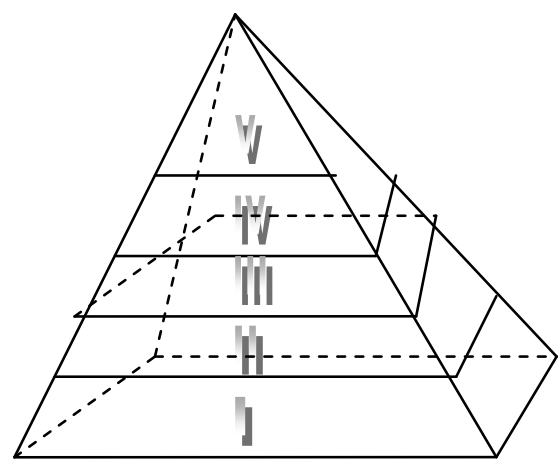

\section{Penjelasan}

a. Sila Pertama mendasari sila II, III, IV, V

b. Sila II didasari sila I mendasari sila III, IV, V

c. Sila III didasari sila I dan II mendasari yang IV dan V

92 Ibid., 54.

93 K.H. Soekamta, Filsafat Manusia. Catatan Kuliah (Surakarta: STT Berita Hidup. Program Pascasarjana, 2006). 
d. Sila IV didasari sila I, II, III mendasari sila V

e. Sila V didasari sila I, II, III, IV

Bagaimana memandang Pancasila yang hirarkis pyramid? Ketuhanan Yang Maha Esa mendasari realitas, sehingga:

Ketuhanan Yang Maha Esa yang berkemanusiaan, ber-persatuan, berkerakyatan dan berkeadilan sosial bagi seluruh rakyat Indonesia.

Kemanusiaan yang adil dan beradab yang berketuhanan, ber-persatuan, berkerakyatan dan berkeadilan social.

Persatuan Indonesia yang berketuhanan, berkemanusiaan, berkerakyatan dan berkeadilan sosial

Kerakyatan yang dipimpin oleh hikmat kebijaksanaan dalam permusyawaratan perwakilan yang berketuhanan, berkemanusiaan, berpersatuan dan berkeadilan sosial

Keadilan sosial bagi seluruh rakyat Indonesia yang berketuhanan, berkemanusiaan, berpersatuan dan berkerakyatan.

Dengan demikian secara ontologis, kesatuan sila-sila Pancasila sebagai suatu sistem yang bersifat hirarkis dan berbentuk pyramidal. Indonesia sebagai negara dengan beragam keyakinan dari agama-agama modern disamping agama-agama suku menjadi tantangan keyakinan yang pluralistik. Sehingga ya atau tidak "prinsip toleransi" beragama menjadi suatu keharusan sebagai jalan menuju kerukunan keragaman beragama.

\section{H. Kepelbagaian dalam Realitas Praksis Bernegara}

Suatu pemikiran awal bahwa gereja harus membangun hubungan yang harmonis dengan Negara.

Harmonius relationship between Religion communities and the government is veri much dependent upon the correct understanding and arrangement of the relationship between state and religion. Namely, how the interrelation of both is formulated Indonesia suc a way that it wiil enable for each to 
perform its funcation as best as possible. Namely, where the State funcation as state, and religion funcations as religion ${ }^{94}$

Bahwa keharmonisan antara agama dan pemerintah adalah sangat dependen dan saling pengertian. Jika ada saling pengertian maka tidak ada masalah yang tidak dapat diselesaikan di antara kedua lembaga ini atau dengan kata lain "agree and disagreement" (setuju dalam ketidaksetujuan)." Dalam hal apa keduanya setuju untuk berjalan bersama - sama dan dalam hal apa tidak saling menyetujui tetapi perlu diketahui bahwa ketidaksetujuan tidak berarti bahwa konflik melainkan dalam asaz.

Kedudukan gereja terhadap Pancasila dipahami berkaitan dengan anggota gereja yang mana sekaligus menjadi warga Negara dan Calvin menyebut keduanya Civita Dei dan Civita Terena. Masyarakat sipil dan negara adalah dua domain yang berbeda dan juga bahwa masyarakat sipil menjadi ajang arena perebutan hegemoni. Masyarakat sipil merupakan wilayah institusi privat yang mencakup gereja, serikat dagang, dan lembaga pendidikan. Di sisi lain, Negara merupakan masyarakat politik, yang di dalamnya terdapat institusi-institusi public seperti pemerintah, pengadilan, polisi dan tentara. Perebutan ini dapat dilihat pada dua wilayah:

Pertama, masyarakat politik dan masyarakat sipil. Sebagai contoh, Franz Magnis Suseno95melalui esay-nya "Antara Pluralisme dan Primordialisme", Romo Magnis mengatakan "setelah 30 tahun Pemerintahan Orde Baru yang tidak lelah berbicara tentang persatuan dan kesatuan, persatuan suku-suku, umat-umat beragama, etnik-etnik dan ras-ras itu nampak rapuh". ${ }^{96}$ Kerapuhan itu berujung pada konflik-konflik komunal, huru-hara dan kerusuhan. Sehingga “jahitan-jahitan karpet nusantara nampak mulai sobek”. Sudah disebutkan bahwa konflik-konflik itu bukan hanya sentiment agama, penduduk asli dan pendatang sebagai konflik horizontal melainkan konflik vertical. Romo Magnis menyebut konflik vertical ini sebagai "konflik antara rakyat dengan the haves,

\footnotetext{
${ }^{94}$ Departemen Agama RI, Bingkai Teologi, 90.

95 Franz Magnis Suseno, Kuasa dan Moral (Jakarta: Gramedia, 2001), 24.

96 Ibid.
} 
antara masyarakat dan mereka. Mereka itu tentu bukan rakyat, tetapi yang kaya dan berkuasa". ${ }^{97}$ Tentu Kedua entitas ini, diperhadapkan dengan perebutan (harus ada yang menjadi lawan - masyarakat sipil versus masyarakat politik) hegemoni.

Kedua, masyarakat politik dan masyarakat agama. Sebagai contoh. Dalam era pertengahan, ada banyak pandangan yang berbeda-beda, tetapi semuanya merupakan variasi-variasi yang menekankan pada dua tema pokok ... Tema yang pertama adalah Dua Pedang (Two Sword), yaitu adanya dua kekuasaan atau dua ruang lingkup pengaruh yang masing-masing mandiri dalam kenyataan hidup ini. "Dua Pedang" ini adalah Gereja dan Kekaisaran, yaitu kekuasaan batin dan kekuasaan lahir. Paus Gelasius I (Paus 492-496) adalah orang yang pertama kali memunculkan ide Dua Pedang ini. Tetapi juga kedudukan Gereja dianggap lebih di atas Negara dalam arti martabat atau nilai dan kedudukan negara dianggap lebih di atas dari Gereja dalam arti kekuasaan fisik dan paksaan walaupun tingkat kekuasaan tepat sama". 98 Baik gereja dan negara merasa berhak, bahkan berkewajiban untuk menuntut kepatuhan dari warganya.

Padahal warga dari kedua lembaga ini adalah sama. Dikatakan dilema karena bila negara mengeluarkan suatu perintah yang pada hakekatnya bertentangan dengan Firman Tuhan maka sikap ketidakpatuhan akan ada dan sebaliknya. Hal senada juga diungkapkan oleh Suzeno mengenai dilema agama dan negara bahwa "Dilema kepatuhan antara agama dan negara dapat menjadi tajam apabila negara diselenggarakan berdasarkan sebuah idiologi yang harus dianut oleh semua anggota masyarakat. Karena idiologi adalah sesuatu yang disamping kepatuhan juga mau menuntut kepercayaan. Padahal kepercayaan adalah wewenang khas agama. "Maka masalah idiologi juga merupakan masalah hubungan antara negara dan agama”. ${ }^{99}$

${ }^{97}$ Ibid.

98 Wenata Sairin dan J.M. Pattiasina, Hubungan Gereja dan Negara dan Hak-hak Asasi Manusia (Jakarta: BPK Gunung Mulia,199), 28.

${ }^{99}$ Franz Magnis Suseno, Kuasa dan Moral, 103. 
Dalam membahas sikap orang Kristen terhadap pemerintah maka perlu diketahui bahwa masalah pokok yang terdapat dalam Roma 13:1-7 adalah apakah orang Kristen harus tunduk kepada pemerintah? Hal ini akan menjadi problem tersendiri bagi orang Kristen sebab jika tidak tunduk maka akan disebut sebagai musuh negara atau pemberontak. Injil atau perkataan Tuhan akan menjadi patokan atau titik tolak bagi orang Kristen di dalam mengambil sikapnya terhadap pemerintah sebab Firman Tuhan merupakan otoritas tertinggi. Roma 13:1 berkata "setiap orang harus tunduk kepada pemerintah sebab pemerintah adalah hamba Allah atau wakil Allah di bumi untuk membalaskan murka Allah kepada setiap orang yang melakukan kejahatan.” Berarti setiap orang tunduk kepada pemerintah sebab pemerintah merupakan wakil Allah di bumi.

Di atas telah disebutkan bahwa Firman Tuhan merupakan patokan bagi orang Kristen di dalam menentukan sikapnya terhadap pemerintah. Oleh karena Firman Tuhan menjadi patokan maka ketundukkan orang Kristen terhadap pemerintah adalah "sejauh tidak bertentangan dengan iman Kristen yang bersumber pada perkataan Yesus atau Firman Tuhan.” Sikap ini oleh Eka Darmaputera disebut sebagai 'ketidaktaatan yang bertanggung jawab'100. Memang orang yang tidak tunduk disebut sebagai orang yang tidak taat namun ketidaktaatan orang Kristen adalah ketidataatan yang bertanggung jawab. Mengapa? Karena orang Kristen tidak tunduk kepada pemerintah jika hal atau aturan yang dikeluarkan oleh pemerintah bertentangan dengan imannya. Misalkan, dalam sejarah gereja, tepatnya pada masa pemerintahan kaisar Caligula, Caligula memerintahkan agar semua orang termasuk orang Kristen menyembah dewa-dewa dan mengikuti ritual-ritual agama kafir pada waktu itu. Hal seperti ini jelas harus ditolak. Tidak tunduk kepada pemerintah itu salah baik secara hukum maupun etika tetapi memberi perintah atau aturan yang melarang atau sesuatu yang bertentangan dengan kepercayaan orang lain pun salah, baik hukum dan etika. Seperti yang terdapat di dalam Undang-undang 
Dasar 1945 pasal 29 ayat 2 "Negara menjamin kemerdekaan tiap-tiap penduduk untuk memeluk agamnya masing-masing dan untuk beribadat menurut agamanya dan kepercayaan itu."Ini merupakan jaminan agar hal itu tidak terjadi. Secara etika pun sebenarnya tidak boleh. Sebab cara seperti itu merupakan cara pembatasan terhadap kebebasan prang lain. Pembatasan kebebasan dapat dilakukan "melalui pewajiban dan larangan."101 Sekalipun seperti apa yang disebut oleh Darmaputera sebagai ketidaktaatan yang bertanggung jawab, namun ketidaktaatan ini pun menyisakan dilema. Dilema ketaatan atau kepatuhan ini akan muncul bila gereja berusaha untuk membatasi diri dengan tujuan agar pesan ilahi tidak dipalsukan oleh unsurunsur dunia. Magnes Suzeno menyebutnya dengan istilah puritanisasi 102

Dilema ini bukan hanya terjadi di dalam gereja namun diluar gereja, yakni agama-agama besar lainnya juga mengalami hal yang sama. Apabila ini yang terjadi maka keloyalitasan terhadap negara akan semakin melemah. Baik gereja dan negara merasa berhak, bahkan berkewajiban untuk menuntut kepatuhan dari warganya. Padahal warga dari kedua lembaga ini adalah sama. Dikatakan dilema karena bila negara mengeluarkan suatu perintah yang pada hakekatnya bertentangan dengan Firman Tuhan maka sikap ketidakpatuhan akan ada dan sebaliknya. Hal senada juga diungkapkan oleh Suzeno mengenai dilema agama dan negara bahwa : Dilema kepatuhan antara agama dan negara dapat menjadi tajam apabila negara diselenggarakan berdasarkan sebuah idiologi yang harus dianut oleh semua anggota masyarakat. Karena idiologi adalah sesuatu yang disamping kepatuhan juga mau menuntut kepercayaan. Padahal kepercayaan adalah wewenang khas agama. "Maka masalah idiologi juga merupakan masalah hubungan antara negara dan agama.”103

Pada kalimat terakhir dari Covenant on Civil and Political Rights pasal 18 ayat 1 disebutkan bahwa setiap anggota masyarakat baik secara individu atau kelompok secara terbuka atau pun tertutup menyatakan kepercayaannya

${ }^{101}$ Franz Magnis Suseno, Etika Dasar (Yokyakarta: Kanisius, 2002), 37.

102 Franz Magnis Suseno, Kuasa dan Moral, 102.

103 Ibid. 
melalui ibadah, ketaatan bahkan di dalam tindakan dan ajaran. Artinya bahwa warga gereja secara terbuka menyatakan ketidaktaatannya bila itu tidak sesuai dengan ajaran agamanya atau jika kebebasannya terancam atau dirampas.

\section{Pluralitas Keyakinan dan Tanggapan}

Problem-poblem cros religion dirasakan sebagai suatu tantangan yang disebut tantangan pluralisme. Dalam tantangan ini, ada satu keinginan yang boleh kita sebut "keinginan luhur" dari beberapa teolog yakni "hidup berdamai atau berdampingan dalam kepelbagaian atau heterogenitas keyakinan" dan berusaha mencari akar permasalahan serta mencarikan solusi atas tantangan pluralisme.

Oleh beberapa teolog pendukung, masalah pluralisme kenyataan kemajemukan agama-agama tidak hanya dilihat sebagai kenyataan sosial belaka ${ }^{104}$ melainkan sebagai masalah serius yang mengancam unitas agamaagama. Ancaman tersebut adalah ancaman eksklusivitas atau dalam metafor yang digunakan Martin Lukito Sinaga adalah metafor "penari" dan "tarian". Dalam metafor ini, penari harus menari sedemikian rupa dengan temantemannya sehingga menghasilkan gerak tari yang indah dalam kekompakan dan kebersamaan. Ada kesepakatan gerak dalam tari agar tidak ada yang bergerak diluar gerak tari atau bergerak berlawanan sebab dampak yang muncul dari gerak tari yang berlawanan adalah kekacauan. Prinsip metafor dalam "penari" dan "tari" adalah tidak ada yang menganggap diri superior atau yang terbaik dalam kelompok tari tersebut. Artinya agama-agama harus bergerak bersama-sama, tidak menganggap agamanya sebagai agama yang superior alias paling benar atau dalam metafor lain "anak tunggal " dan "anak sulung". Khususnya dalam Kekristenan, pengakuan akan Kristus tidak harus mengenyahkan dan mengeleminir realitas keyakinan agama lain. Pemikiran ini

104 Martin Lukito Sinaga, Meretas Jalan Teologi Agama-agama di Indonesia (Jakarta: BPK Gunung Mulia), 1. 
bersumber pada buku dari Paul Knitter No Other Name?105. Disamping itu John Hick dan Paul Knitter bersama-sama menyunting "Mitos Keunikan Agama Kristen".

Dalam usaha tersebut, tidak hanya bergerak pada tingkat praksis melainkan pada tingkat akademis. Di tingkat akademis teologis disebut studi Teologi Agama-agam atau Teologia Religionum bahkan ada yang mengusulkan bahwa Teologi Agama-agama seyogyanya dimengerti terpisah dengan Ilmu Agama-agama. Sebab teologi Agama-agama di dalamnya memuat refleksi teologis yakni untuk menerima dan mengakui keyakinan lain seperti yang diungkapkan oleh Martin Lukito Sinaga bahwa dalam hubungan dengan agama lain kaum kristiani menerima dan mengakui agama lain dengan seluruh ajarannya selaku agama atau jalan yang benar dan menjadi bagian penting dalam rencana Allah bagi seluruh ciptaan-Nya dengan dasar iman Kristen.

Teologi yang mendasari anggapan itu adalah, kurang lebih, dan dengan rincian berbeda, anggapan bahwa agama-agama merupakan ekspresi religiositas umat manusia. Para pendiri agama, seperti Buddha, Yesus, dan Muhammad merupakan genius-genius religius, mereka menghayati dimensi religius secara mendalam. Mereka, mirip dengan orang yang bisa menemukan air di tanah, berakar dalam sungai keilahian mendalam yang mengalir di bawah permukaan dan dari padanya segala ungkapan religiositas manusia hidup. Posisi ini bisa sekaligus berarti melepaskan adanya Allah personal.

Berbicara tentang teologi agama-agama atau pluralitas keyakinan dari agama-agama tidak terlepas dari rancang bangun teologi agama-agama yang telah dibangun oleh para teolog pluralis yakni bagamana memahami keyakinan agama lain. Dalam memahami keyakinan agama lain ada harapan untuk betemu dalam ruang dialog yang tentunya bersedia melepas keyakinan tradisional/historis/ortodoks.

Teologi agama-agama/religionum merupakan bentuk keprihatinan dari teolog seperti John Hick, Paul Kniter dan teolog lainnya mengenai kekerasan yang bermotifkan agama atau karena radikalisme dan bentuk anggapan bahwa 
agama-kulah yang paling benar dan yang lain tidak. Dalam catatan sejarah agama-agama, kekerasan menjadi momok dalam perkembangannya sebab sejarah agama-agama warnai oleh pertumpahan darah, perang, pengorbanan dan pengkambinghitaman ... fakta brutal dari sejarah agama-agama yang brutal menunjukkan bahwa antara agama dan kekerasan jalin-menjalin. Kekerasan dengan "pakaian agama" berulangkali mempesona agama dan kebudayaan, memikat masyarakat "santun", kaum akademisi dan rohaniawan ke dalam tarian yang menghancurkan. ${ }^{106}$ Sebab kekerasan merupakan "suatu usaha individu atau kelompok untuk memaksakan kehendaknya terhadap orang lain melalui cara-cara non verbal, verbal atau fisik yang menimbulkan luka psikologis atau fisik. ${ }^{107}$ Ini tentu agama dengan sifatnya yang luhur "ternodai" oleh "nafsu dan keserakahan manusia", manusia mengatasnamakan agama sebagai jalan menuju primordialisme, pemaksaan dan kekerasan.

Mengenai kekerasan, menyetujui pemikiran Rene Girard yang dikutip oleh Lefebure108 pada bagian "Penyataan Allah sebagai Penyingkapan Kedok Kekerasan”. Dalam penyelidikan Girard, Girard menemukan hubungan saling pengaruh antara agama dan kekerasan. Bahwa "akar-akar semua agama, kecuali Yudaisme dan kekristenan, adalah pengaturan kekerasan ke dalam langkah-langkah yang dapat dikembalikan. Ia mengusulkan teologi orisinal tentang penyataan yang di dalamnya terdapat pokok sentral mengenai mimesis (imitasi) dan kekerasan ... agama-agama membenarkan dan mensakralkan kekerasan atas nama Allah atau dewa-dwa. Hanya pernyataan alkitabiahlah yang berpihak kepada korban dan menyingkapkan mekanisme kekerasan sehingga dapat diatasi. 109 Contoh dari konsep mimetis Girard adalah catatan Biblis tentang Hamba Tuhan yang menderita dalam Deotero Yesaya yang menampilkan drama mitologis purba di mana "orang banyak mengelilingi korban (manusia) yang takbersalah dan tak henti-hentinya mencaci-maki

${ }^{106}$ Leo De Lefebure, Penyataan Allah, Agama dan Kekerasan (Jakarta: BPK Gunung Mulia), 2009.

107 Ibid., 20.

108 Ibid.

109 Ibid. 
korban. Namun ada perubahan titik pandang. Penulis alkitab menolak tuduhan; korban tidak bersalah dan dibenarkan oleh Allah - Yesaya 52:13-53:12.

Dari keprihatinan tersebut maka ada kerinduan dan harapan luhur dari para pencetus teologi agama-agama. Benarkah demikian? Dari literaturliteratur tentang tema tersebut ada kesan yang muncul yakni kesan "keinginan keadilan sosial religius" dari para pencetus. Artinya juga bahwa para pemuluk dari berbagai keyakinan juga tentu harus melakukan rethinking terhadap ajaran-ajaran dan bersedia melepas keunikan sebab keunikana sebagai dasar persoalan. Misalnya, dalam Kekristenan, Yesus tidak dipandang sebagai sentra kebenaran dan sebagai yang unik.

Di alinea ini dan selanjutnya, kita akan mencoba mengerti pergumulan para pencetus teologi pluralisme agama, yang dinyatakan oleh Th. Sumartana. Pertanyaan yang hendak kita pergumulkan bersama adalah, tantangan pokok macam apakah yang dihadapi oleh agama-agama sekarang ini? Dan bagaimana tantangan tersebut telah memberi dampak pada agama-agama; serta bagaimana agama-agama memberi respons terhadap tantangan tersebut? Perubahan-perubahan apakah yang telah terjadi, dan bagaimana perubahan itu mempengaruhi pola pikiran, institusi dan kegiatan agama-agama? Bagaimana pula tantangan tersebut akan mewarnai masa depan dari agama-agama serta hubungan antaragama?

\section{J. Kesimpulan}

Tantangan keagamaan yang mendasar yang kita hadapi sekarang ini bisa kita ungkap dengan satu kata, yaitu pluralisme. Tidak ada maksud untuk mengatakan bahwa pluralisme merupakan satu-satunya tantangan, akan tetapi bila tantangan tersebut tidak diperhatikan dengan sungguh-sungguh maka agama-agama akan kehilangan persepsi yang benar tentang dunia dan masyarakat di mana mereka hidup. Pluralisme telah menjadi ciri esensial dari dunia dan masyarakat sekarang. Dunia telah menjadi satu dan menjadi sebuah kampung kecil di mana umat manusia hidup bersama di dalamnya. Kelompokkelompok masyarakat hidup saling berhubungan, saling tergantung satu 
terhadap yang lain. Jaringan komunikasi telah menembus tembok-tembok yang tadinya mengisolasi kelompok-kelompok agama di masyarakat.

Pluralisme bukan sekadar multiplikasi kepelbagaian, bukan hanya ekstensif, akan tetapi kualitatif. Pluralisme masa sekarang, jenis, bentuk dan isinya berbeda dengan pluralisme yang kita alami di masa lampau. Pluralisme masa lampau menuntut suatu respon kerukunan, ko-eksistensi, dan keserasian hidup dari kelompok-kelompok agama di masyarakat. Corak kepelbagaian itu bersifat pasif, kalau kita mendatanginya kita baru mengalaminya; akan tetapi pluralisme sekarang ini bersifat sangat aktif, kalau kita tidak mempedulikannya maka kita akan digilasnya.

Pluralisme di masa sekarang terjadi karena tiap-tiap kelompok itu sudah mengalami proses emansipasi sedemikian rupa, sehingga setiap bagian itu sudah melakukan emansipasi bersama, dan tampil bersama secara setara. Tidak ada orang bisa bilang bahwa sesuatu pihak tak punya hak untuk tampil. Dengan demikian bisa dikatakan, bahwa pluralisme jenis yang sekarang ini tampil bersama dengan kesadaran emansipatoris dari setiap kelompok yang ada di masyarakat. Kenyataan semacam ini melahirkan urgensi baru untuk memahami serta menanggapinya secara baru.

Juga secara kuantitatif, pluralisme di masa sekarang jumlahnya lebih banyak dan lebih kompleks dibanding dengan yang ada di masa lampau. Ini yang disebut multiplikasi kepelbagaian. Muncul kombinasi-kombinasi serta berbagai bentuk campuran dari berbagai agama yang muncul yang menambah jumlah kelompok-kelompok agama tersebut, baik secara intern maupun ekstern. Di satu pihak kita melihat jumlah denominasi gereja bertambah, teapi jumlah agama bertambah pula. Ada gejala yang kita sebut "New Age", ada begitu banyak "sekte-sekte" sempalan yang merupakan campuran dari berbagai macam agama, dan juga kombinasi agama dengan berbagai bentuk ideologi.

Ia berada diluar jangkauan pikiran manusia namun Ia terbuka untuk dipahami. Dengan Ia membuka diri berarti Ia meretas jalan bagi manusia untuk memahami diri-Nya. Di tahap ini manusia mulai mengekspresikan emosi religiusitasnya dalam berbagai rupa dan bentuk. Hal ini dapat kita tangkap 
melalui ritus-ritus. Seperti apa manusia memahami Sang Absolut demikianlah ia akan mengekspresikan keyakinannya yang terbalut emosi. 


\section{BAB ENAM}

\section{ISU PLURALISME DAN TANTANGAN MISI}

\section{A. Pendahuluan}

Melihat kilas balik sejarah agama agama di masyarakat Indonesia, sebelum agama-agama dari luar masuk dan masyarakat Indonesia menjadi pemeluk agama non pribumi, semua beragama animisme. Ketika Hindu dan Budha masuk ke nusantara, yang dibawa dari India dan negara Asia lainnya, penetrasi dan interaksi secara alami terjadi. Asimilasi dengan budaya lokal Indonesia membuat agama Hindu dan Budha bertahan sampai hari ini. "Kekeristenan mendarat pertama di Indonesia abad ke 7, dan menghilang tanpa ada kejelasan detail, sampai akhirnya muncul kembali di Abad 11 di mana Islam mulai merambah nusantara. Kekeristenan mulai hadir dan mulai melakukan misi nya kembali di abad ke 16".110 Islam masuk ke Indonesia sekitar abad ke 10 atau ke 11 yang dibawa oleh pedagang dari Gujarat India. Islama kala itu berinteraksi baik dengan masyarakat lokal dan budaya lokal, diterima dengan baik oleh penduduk setempat. Tetapi ketika Islam telah menjadi dominan dan pemerintah dikuasai, penduduk lokal "terpaksa" dan di paksa untuk memeluk agama”. ${ }^{111}$ Kemudian di abad 18 dan 19, ketika Timur Tengah mengalami kebangkitan dan pemurnian Islam, kegerakkan ini juga sampai ke Indonesia. Keterbukaan Islam terhadap agama lain semakin terbatas". 112

Ketika kekristenan kembali bangkit di awal abad ke tujuh belas (17), bersamaan dengan datangnya penjajahan Portugis dan Spanyol, kekuatan

110 Jan S. Aritonang, A History of Christianity in Indonesia:Studies in Christian Mission, ed. Jan S. Aritonang dan Karel Steenbrink (Boston: Brill, 200), 3.

111 Jan S. Aritonang, A Glimpse of plurality of Religious and Faiths in Indonesia, (Asian Society of Misiology, 2018), 30.

112 Jan S. Aritonang, Sejarah Perjumpaan Kristen dan Islam di Indonesia (Jakarta: BPK Gunung Mulia, 2004), 137-228. 
imperialisme dan kolonialisme tidak bisa menyentuh masyarakat etnik atau setempat, juga penduduk yang sudah bergama Islam. Begitu juga ketika Belanda mengambil alih penjajahan di bumi Nusantara.

Sejak awal abad ke sembilan belas (19), gerakan misionari Barat yang dimotori oleh Protestan dan Katolik, yang dimotori kebangunan Rohani di Eropa, juga merambah indonesia. Tetapi sejak Belanda masuk ke Indonesia yang di motori oleh VOC, orientasi dagang menjadi tujuan utama membuat penekanan dan penjangkauan terbatas.

Setelah Indonesia mendekati kemerdekaan dan persiapan merdeka 1945, dan pergumulan mempertahankan kemerdekaan, membuat semua agama dan semua etnik penduduk bersatu padu hidup dalam harmoni. Tetapi ketika pemerintahan mulai mengkonsep dasar dan fondasi ideologi bangsa, terjadi tarik ulur untuk menentukan dasar konstitusi. Sebagian mengingini menjadi negara Islam dan yang lain tidak menghendaki. Menurut Muhjiburahhman, dalam tulisannya "Feeling Threatened", "perasaan terancam umat Muslim sebenarnya terjadi sejak abad ke 11 sampai abad ke 13, di mana terjadi perang salib di semenanjung Iberia dan perebutan kekuaasaan dan pengaruh, dan perasaan terancam itu terbawa-bawa sampai abad kini. ${ }^{113}$

Untuk mengatasi isu yang berkembang, Pachuau mengatakan bahwa, "whereas on a grassroot level believers of different faith often live peacefully together, the situation changes when in such context a religious group identity becomes a political factor, as in Indonesia where Christians and muslim clash".114 Jonathan Fox, ${ }^{115}$ menganalisa tulisan Samuel Huntington dalam bukunya "The Clash of Civilizations" didahului hipotesis bahwa identitas budaya dan agama orang akan menjadi sumber utama konflik di dunia pascaperang dingin. Fox berpendapat bahwa perang di masa depan akan terjadi

113 Mujihburrahman, Feeling Threatened Muslim-Christian in Indonesia New Osrder (Amsterdam: Amsterdam University Press, 2006).

114 Pachuau Lalsangkima dan Jørgensen Knud, Witnessing to Christ in a Pluralistic World Christian Mission among Other Faiths (Edinburg: Regnum, 2010), 18.

115 Jonatahan Fox, Ethnic Minorities and the Clash of Civilizations: A Quantitative Analysis of Huntington's. Thesis (Cambridge: Cambridge University Press, 2002), 257-258. 
bukan antar negara, tetapi antar budaya, dan bahwa ekstremisme akan menjadi ancaman terbesar bagi perdamaian dunia.

\section{B. Perlunya Teologi Pluralisme}

Masyarakat Indonesia memiliki berbagai latar belakang yang berbeda satu dengan yang lainnya. Adanya keberagaman atau perbedaan itu mempengaruhi bahasa, budaya, kepercayaan. Secara sosiologis, masyarakat Indonesia adalah masyarakat religius dan mudah menerima kebudayaan yang membawa nilai-nilai spiritual.

Membangun pluralisme merupakan imbauan menerima kemajemukan merupakan sebuah tatanan masyarakat yang saling mengerti bahwa pada hakekatnya mereka merupakan kesatuan dalam kepelbagaian. Pluralisme adalah suatu kondisi dimana adanya keberadaan sesuatu yang beragam. Pluralisme agama berarti "semua agama berhak untuk ada dan hidup". Secara sosial, kita harus belajar untuk toleran dan bahkan menghormati iman atau kepercayaan dari penganut agama lainnya. Oleh karena itu, Penulis memandang bahwa faktor-faktor di bawah ini setidaknya dapat membawa pengaruh buruk terhadap upaya membangun teologi pluralisme.

\section{Sensasionalisme Agama-Indoktrinasi Pikiran}

Pikiran adalah bagian terpenting dari manusia, dan hidup kita hanyalah luapan dari pikiran kita. Pikiran kita menjadikan kita apa adanya. Sikap mental kita adalah faktor penting yang menentukan nasib kita. Sebuah pepatah lama menyatakan, "Pikiran menghasilkan tindakan, tindakan menghasilkan kebiasaan, dan kebiasaan menghasilkan karakter." Filsuf Romawi, Marcus Aurelius, berkata, "Hidup kita adalah apa yang dipikirkan oleh pikiran kita (Our life is what our thoughts make it). ${ }^{116}$ Apa yang terjadi di banyak belahan dunia, khusunya tempat-tempat yang rawan konflik agama, maka media massa menjadi alat paling ampuh yang digunakan oleh kaum oportunis untuk 
memanipulasi massa dengan mengubah fakta. Ini membentuk opini dan sikap serta mendefinisikan apa yang normal dan dapat diterima. Penekanan berlebihan pada sisi negatif agama dan tindakan ekses agama menimbulkan ketakutan dan permusuhan antar agama. Terlebih lagi, media menggambarkan isu-isu agama dengan cara yang sensasional sehingga membingungkan daripada memberi informasi, menghasut dan menimbulkan kemarahan. Hal itu dilakukan dengan salah memahami tujuan dan aliansi antar agama, sehingga memperburuk polarisasi. Skenarionya diperburuk oleh media sosial seperti WhatsApp, Facebook, Twitter dan lain-lain. Di mana pengguna cenderung menabur benih kebencian dan ketidakpuasan. Penangkal koeksistensi di antara pengikut agama yang berbeda sebagai orang percaya yang taat beragama yang takut akan Tuhan dan menghormati Tuhan, kita ingin menjadi saleh dan religius. Namun banyak dari kita memiliki bentuk kesalehan, penampilan lahiriah yang religius, tidak benar-benar memanifestasikan kebenaran dari Pengajaran Suci. Kita harus mengakui bahwa bentuk tanpa kekuatan, agama tanpa realitas adalah kesombongan. Tidak heran Mahatma Gandipernah berkata "agama tanpa pengorbanan, ilmu pengentahuan tanpa karakter, yang dapat membuat suatu isu begitu cepat berkembang dan merugikan pengikut atau ajaran agama tertentu". ${ }^{117}$

Oleh karena itu, komunitas agama perlu memikirkan kembali tanggung jawab agamanya untuk bekerja sama, dan bahkan dalam beberapa hal bertindak sebagai agen rahmat umum Tuhan dalam mempromosikan hidup berdampingan secara damai dan harmonis di antara orang-orang dari semua agama. Mengutip Kim Kong mengingatkan kita tentang "faktor-faktor superioritas dapat membuat orang bisa menjadi intoleran terhadap orang kepercayaan orang lain". 118

\footnotetext{
117 Mahatma Gandhi, Seven Deadly Sins. //http.www.mkgandhi.org di akses, Juli 2018.

118 Wong Kim Kong, Human Rights in Religion Coexistence among followers of Different Religion. (DOHA: Interfaith Dialogue Conference, 20-21 February.2018).
} 


\section{Dogmatisme Agama - Sumber Laten Intoleransi}

Penganut agama yang taat akan hidup dan menjalankan agama mereka sesuai dengan ajaran Kitab Suci mereka. Meskipun tidak harus demikian, ada beberapa aspek dari ajaran agama yang dapat menyebabkan orang-orang percaya rentan terhadap dogmatisme. Doktrin atau ajaran secara sadar atau tidak sadar mengembangkan keyakinan yang kuat, suatu keadaan menjadi percaya diri dan yakin akan kebenaran dan kepercayaan agama mereka. Keyakinan akan Kata-Kata Suci mereka menjadi indeks absolut untuk seluruh hidup mereka - iman dan praktik. Ini adalah kata yang datang dari Tuhan mereka, mau tidak mau, tidak hanya mereka tidak dapat mengkompromikan kepercayaan mereka, tetapi dapat menyebabkan ketidakfleksibelan dan intoleransi di hadapan kepercayaan lain. Jadi, orang-orang percaya cenderung membawa keyakinan mereka. Dengan demikian menjadi sumber konflik.

\section{Ekstremisme Agama atau Fanatisme - Kekuatan Agresi yang Jelas}

Ekstremisme agama sedang meningkat. Agama dan fanatisme berasal dari keyakinan agama yang kuat dan dogmatisme dari kepercayaan mereka. Mereka percaya langkah-langkah radikal dan tanpa kompromi diperlukan untuk memenuhi mandat atau perintah Tuhan. Ekstremis agama memegang posisi bahwa jika orang lain yang tidak mengikuti cara mereka atau menentang mereka, mereka akan dikutuk. Jika ada pilihan antara yang baik dan yang jahat, Tuhan dan dunia, para ekstremis agama akan merasa sulit untuk membenarkan atau berkompromi dengan dunia dan kejahatan. Tanda-tanda moderasi dapat dikecam sebagai penjualan habis, yang lebih penting, meninggalkan kehendak Tuhan. Sebagai hasil dari keagresifan dan kegigihan pandangan mereka, para ekstrimis ini sering mengajarkan intoleransi terhadap semua yang tidak setuju dengan pandangan mereka sendiri. Sehingga menimbulkan konflik. 


\section{Agresi Agama - Akhir dari Konfrontasi Agama}

Manifestasi keagamaan bisa menular. Dogmatisme agama mengarah pada keyakinan agama yang tidak kenal kompromi; keyakinan agama mengarah pada agresi agama biasanya disebabkan atau dibenarkan karena dianggap melanggar hak; ancaman terhadap agama mereka; oposisi terhadap kehendak ilahi Allah; dan tindakan atau kebijakan diskriminatif lainnya dari pemerintah. Ketika penganut agama merasa hak kebebasan berkeyakinan mereka dibatasi atau didiskriminasi, di mana tidak ada proses konstitusional atau hukum yang sah untuk mengekspresikan pandangan mereka atau untuk membela hak-hak mereka, mereka mungkin lebih cenderung menggunakan kekerasan. Dengan demikian menghasilkan bentuk kuat nasionalisme non-liberal yang secara berkala mengarah pada intoleransi dan diskriminasi.

\section{Dakwah Agama - Semangat Perang di Tempat Kerja}

"Bagaimana kita menyelesaikan konflik agama sebagai akibat dari dakwah?" Jelas, dia merujuk pada Islam dan Kristen. Jawaban saya adalah: "Penganut agama yang taat beragama akan berkhotbah tentang agama mereka. Orang-orang percaya dipanggil untuk menyebarkan firman Tuhan dan menambah jumlah iman. Pengabdian seperti itu wajar dan netral. Tindakan proselitisasi menjadi tidak sensitif, koersif, agresif, dan tidak bermoral, maka bisa menimbulkan konflik. Demikian pula, segala upaya untuk memaksakan agama mereka kepada orang lain terutama melalui cara politik bisa menjadi perdebatan". Semua contoh ini berasal dari kurangnya rasa hormat terhadap agama lain.

6. Fundamentalisme Agama- Reaksi Antagonistik terhadap Postmodernisme

Asumsi postmodern, yang sebagian besar tidak dipertanyakan, adalah bahwa kepercayaan pada dasarnya adalah masalah preferensi; bahwa tidak ada realitas pamungkas; bahwa oleh karena itu semua pernyataan keyakinan yang 
penuh keyakinan harus dianggap sombong. Bersama-sama dengan kemunculan pluralisme dan materialisme yang mencolok dalam masyarakat dan pendukung sekularisme militan, mereka menjadi penghinaan terhadap fundamentalis agama. Mereka melihat liberal yang menopang pikiran modern mengancam kepercayaan dan praktik keagamaan mereka. Masalah aborsi, permisif seksual, pernikahan sesama jenis, bahkan teori evolusi menjadi perdebatan.

Para fundamentalis agama terutama didorong oleh ketidaksenangan dengan mengejar postmodernitas. Termotivasi oleh marginalisasi agama dalam masyarakat modern, mereka bertindak untuk mengembalikan iman ke tempat sentral. Ada kebutuhan untuk pemurnian agama di mata kaum fundamentalis.

Memahami aspek pluralisme yang sejalan dengan Bhineka Tunggal Ika ada beberapa hal yang menjadi isu, hal yang harus ditelaah ulang adalah mengapa nilai-nilai toleransi muncul juga dengan mendekonstruksi pemahaman dan kadangkala sering bercampur dengan pengecilan nilai akan keselamatan Kristus.

Membangkitkan dan menghargai Pluralisme, yang diperlukan adalah perubahan menyeluruh dari orientasi sikap dan perilaku kita terhadap agama satu sama lain dan untuk berusaha membangun koeksistensi yang damai dan harmonis di antara orang-orang dari semua agama. Komunitas agama perlu semakin ditantang untuk mengembangkan jenis pikiran dan sikap yang radikal yang mau menghitung biaya hubungan koeksistensi yang berkelanjutan. Orangorang percaya dari semua agama harus dilihat dalam promosi dan praktik perdamaian dan harmoni; menunjukkan rasa kebersamaan dan kesatuan yang dalam di suatu negara. Ada tembok perlawanan di pikiran dan sikap penganut agama. Pikiran dan sikap tidak hanya membangun tembok perlawanan Pikiran adalah poros umum dan dasar dari keberadaan kita. Itu adalah dasar dari tindakan kita, inti dari kemanusiaan kita. Pikiran kita adalah hal terpenting tentang kita, dan hidup kita hanyalah luapan dari pikiran kita, sebagaimana Alkitab katakan dalam Filipi 4:8 Jadi akhirnya, saudara saudara, semua yang benar, semua yang mulia, semua yang adil, semua yang manis, semua yang 
sedap didengar, semua yang disebut kebajikan dan patut di puji, pikirkanlah semuanya itu.

\section{Pluralisme Agama dan Konflik}

Para pelaku konflik agama adalah orang-orang percaya yang pikiran dan sikapnya begitu sibuk dengan dogmatisme, fanatisme, dan ekstremisme sehingga mereka menjadi disengaja, keras kepala, dan dominan. Proses rekonsiliasi dan membangun hubungan dimulai dengan para pemimpin agama. Ada kebutuhan untuk menjauh dari kecenderungan dan mentalitas ini. Kita harus berhasrat untuk menembus penghalang di dalam dan di sekitar kita, pada saat yang sama dapat mendengarkan dan memahami satu sama lain, tidak menyangkal nilai dan pentingnya masing-masing agama. Tugas mempromosikan koeksistensi religius adalah tugas yang membutuhkan kerja sama antar agama dan salah satu rintangan terbesar untuk kerja sama itu adalah pengertian agama yang sempit yang tidak jauh dari batas agama.

Pluralisme agama berarti bahwa "semua pandangan moral dari masingmasing agama bersifat relatif dan sah menurut penganutnya". Jika kita menganut pluralisme agama dalam nuansa etis, kita didorong untuk tidak menghakimi penganut agama lain yang memiliki pandangan moral berbeda.

Menghindari konflik horizontal antar agama, pemeluk agama harus bersedia untuk mengarahkan kembali pikiran dan sikap dan berani mengakui:

- Ketidakcukupan pengetahuan tentang agama lain. Keyakinan dogmatis tentang iman tidak hanya mengarah pada ketidak fleksibelan dan intoleransi di hadapan kepercayaan lain, menjadi lebih unggul secara agama. Rasa bangga menghalangi penganut keyakinan seseorang untuk mencari pengetahuan dan pemahaman tentang agama lain. Perhatian yang perlu diambil adalah bahwa mendekati masalah apa pun dari sudut pandang pengetahuan superior saja tidak memadai, dan berbahaya. Karena masingmasing pihak dalam argumen iman akan memiliki setidaknya pemahaman tentang kebenaran Allah. Tetapi jika hanya menekankan pengetahuan 
tentang kebenaran, pasti akan mengembangkan kesombongan rohani, kesombongan yang tahu lebih banyak dan lebih baik dari pada yang lain. Tetapi pada kenyataannya pemahaman manusia mana pun tentang kebenaran tidak lengkap dan oleh karena itu, perlu mengakui ketidak cukupan pengetahuan kita, kita perlu mengetahui dan memahami keyakinan agama-agama lain untuk memfasilitasi promosi koeksistensi. Dialog agama diperlukan.

- Kita semua adalah manusia yang tidak sempurna dan lemah dalam karakter kita. Rasa superioritas spiritual memunculkan pembenaran diri. Itu adalah sikap bahwa menganngap diri lebih baik dari yang lain, bahkan dosa, karakter diri lebih baik daripada yang lain. Kebanggaan murni dan pemuliaan diri ini cenderung mengangkat diri sendiri dan meyakini kesempurnaan karakter. Sikap orang-orang Farisi secara langsung, puas dengan kebenaran mereka. Standar subyektif yang ditentukan sendiri ini memisahkan komunitas, sehingga menakutkan koeksistensi yang damai dan harmonis. Alkitab berkata, "Karena semua orang telah berbuat dosa, dan telah kehilangan kemuliaan Allah." "Mengapa engkau melihat selumbar yang ada di mata saudaramu, sedangkan balok di dalam matamu tidak engkau ketahui. Kccenderung fokus pada dosa orang lain, kita tidak memperhatikan dosa sendiri. Jangan sampai kita dibutakan oleh kelemahan karakter dan perilaku kita sendiri. Secara sadar, sikap membenarkan diri sendiri ini akan membangun tembok secara langsung, ketika kita merendahkan orang lain karena kesalahan mereka ketika saya harus fokus pada diri saya sendiri daripada mereka. Itu membangun tembok secara tidak langsung bahkan jika kita tidak mengatakan apa-apa karena sikap hati kita akan disampaikan oleh perlakuan kita terhadap orang lain, karena kesombongan diri saya sendiri yang benar. Untuk hidup dengan rendah hati dan anggun menerima satu sama lain, kita perlu mengenali kelemahan manusia dari karakter kita dan juga kegagalan dalam praktik keagamaan kita.

- Memperbaiki kesalahpahaman antar agama dan praktik masing-masing; Kesalah pahaman tentang keyakinan dan praktik keagamaan mengarah pada 
pemahaman dan persepsi salah tentang iman satu sama lain. Dengan demikian, konsepsi yang salah tidak hanya menciptakan ketidakpercayaan, tetapi juga menghakimi satu sama lain. Penyimpangan atau pendapat yang tidak berdasar ini bisa merupakan hasil dari pemalsuan kebenaran, miskomunikasi, kurangnya pemahaman atau informasi yang salah. Banyak yang salah informasi tentang niat satu sama lain, dan ketika mereka mendengar fakta mereka menjadi lebih ramah dan menerima. Karena itu, kita harus siap untuk berkomunikasi secara terbuka dengan anggota agama lain. Kita tidak tahu bagaimana mengatakan hal yang benar dengan cara yang benar. Jika kita adalah pemimpin agama, kita harus berusaha untuk berdialog satu sama lain. Kita harus siap untuk mendengarkan, mengajukan pertanyaan, terlihat bodoh, dan rentan terhadap pertanyaanmenyelidik orang lain. Kita harus belajar melangkah keluar dari kehidupan religius arus utama. Tetapi apakah orang menerima atau tidak, kita harus belajar menerima kritik dengan patuh, mengetahui bahwa dengan melakukan itu kita menghilangkan kerentanan kesalahpahaman. Kita dapat bereaksi secara melindungi diri sendiri atau dengan keterbukaan yang pada kenyataannya satu-satunya cara menuju kedalaman realitas yang lebih besar.

- Menerima peran saling melengkapi kebaikan dan kekuatan satu sama lain. Isolasi sosial dan individualisme memunculkan disintegrasi dan fragmentasi sosial. Mereka memisahkan interaksi peran dan fungsi kontribusi keagamaan kepada masyarakat. Dengan demikian, mereka memengaruhi keegoisan dan keterpusatan pada keterlibatan diri. Karena itu kita perlu mendengarkan dan belajar dari satu sama lain sehingga masing-masing agama dapat memberikan kontribusi yang khas untuk kesejahteraan kerukunan beragama. Untuk memberikan beberapa contoh nyata, mungkin kita bisa belajar untuk:

- Orang-orang Muslim dapat mengajari kita tentang puasa satu bulan mereka selama "Ramadhan." Praktek keagamaan yang saleh ini penting bagi umat Islam yang sulit dilakukan atau dipraktikkan oleh agama lain. 
- Orang-orang Kristen membawa spiritualitas pribadi yang mendalam di mana penekanan pada pertobatan dan kekudusan pribadi, bersama dengan kepedulian sosial, dan nyanyian pujian dan nyanyian pujian yang agung. Umat Budha tidak percaya pada kehidupan kekal (surga) sebagai tempatbersama Allah. Budhisme percaya pada Nirwana dan Reinkarnasi. Nirwana adalah Keadaan Damai yang membahagiakan, yang merupakan kepadaman segala perpaduan yang bersyarat. Bagi Budhisme, tidak ada neraka dalam definisi "tempat dan kondisi dimana Allah menghukum manusia". Yang ada adalah reinkarnasi bagi mereka yang belum mampu memadamkan keinginan-keinginan duniawinya.

- Hindu menunjukkan diri sejati seorang individu yang tidak dapat diidentifikasi dengan fenomena, esensi dari seorang individu. Untuk mencapai pembebasan, seorang manusia harus memperoleh pengetahuan diri, yaitu menyadari bahwa diri sejati seseorang identik dengan diri Brahman yang transenden. Taoisme, Taoisme adalah tradisi keagamaan atau filosofis yang berasal dari Cina yang menekankan hidup selaras dengan Tao "Jalan". Tao adalah gagasan mendasar yang menunjukkan prinsip yang merupakan sumber, pola, dan substansi dari segala yang ada.

Meskipun tidak ada salahnya mempertahankan atau menjaga keyakinan agama kita secara agama, adalah tidak etis atau tidak bermoral untuk mengutuk atau menilai kepercayaan atau praktik kepercayaan lain. Kita juga harus bertobat dari perasaan superioritas dan pembenaran diri kita. Perlu disadari bahwa betapapun benarnya doktrin kita, kita sering melewatkan kebajikan sejati dari keyakinan kita; betapapun menariknya praktik kita, kita kadang-kadang terlalu sibuk dengan pembicaraan kita tetapi kita hanya di jalan di tempat.

Membangun hubungan yang kuat dan tulus dengan penganut agama lain memungkinkan perhatian individu dan juga kemampuan untuk mengembangkan kepercayaan. Dengan berinteraksi dengan mereka, kita dapat belajar memahami dan menerima satu sama lain dengan cara yang bermakna dan konstruktif. Untuk meningkatkan hubungan antar agama yang berbeda, 
sangat penting, kita saling mengenal. kita harus mengambil setiap kesempatan untuk bertemu bersama, terlibat dalam dialog satu sama lain, dan dengan sopan mengedepankan bentuk kepercayaan yang benar-benar religius.

\section{Pluralisme dan Tantangan Misi}

Pluralisme: peluang ataukah tantang bagi misi menjadi judul makalah ini. Pokok pluralisme diangkat dalam konteks misiologi dalam tindakan bermisi dilatarbelakangi oleh ketersediaan bahan berkaitan dengan pluralisme, yang mana, penulis pernah mengangkatnya dalam Jurnal Stulos dengan judul "Pluralisme Keyakinan dalam Konteks Ke-Indonesiaan". Karena itu, penulis kemudian memahami kembali pokok pluralisme dalam konteks teologia Misiologi.

Penulis berpendapat bahwa, pluralisme keyakinan dapat menjadi tantangan bagi gereja dalam bermisi, namun bisa saja menjadi peluang. Tantangan, karena, pertama, persoalan historis, kedua, SKB tiga menteri tentang kerukunan umat beragama, ketiga, radikalisme agama yang melahirkan ormas-ormas Islam yang ditengarai berkaitan dengan pendekatan terhadap teks kitab suci.

Peluang, karena, di tingkat elit tokoh agama atau cendikiwan khususnya NU dan sebagian Muhammadiyah juga memiliki pandangan yang pluralis. Misalnya, Gus Dur (alm), Nur Colis Madjid (alm), Komarudin Hidayat, Ulil Abshar Abdalla, Lakpesdam NU, JKT ( Tokoh muda dari NU yg banyak nulis di koran-koran, Koordinator JIL). ${ }^{119}$

Konflik-konflik lintas agama seakan berbicara bahwa "tanda dari sebuah perbedaan keyakinan adalah konflik atau perang". Benar bahwa kita tidak dapat menafikan pluralisme keyakinan di bumi Indonesia. Komarudin Hidaya dalam "Agama dalam Dialog", berkata bahwa, "secara sosiologis kita sekarang ini berada dalam lingkaran globalisme dan pluralisme etnis, dan agama, suatu

119 Ust. Hartono Ahmad Jaiz, Aliran \& Paham Sesat di Indonesia (Jakarta: Pustaka AlKautsar, 2002), 235-236. 
keniscayaan sosial antropologis yang harus kita terima". ${ }^{120}$ Benar bahwa ini fakta yang tidak dapat ditepis. Bahkan Komarudian Hidayat memandang hal ini sebagai yang harus direnungkan kembali oleh para teolog, baik Yahudi, Kristen dan Islam dalam mengkaji kembali konsep misionarisme dan konsep monopoli keselamatan eskatologis di luar iman mereka masing-masing.

Pemikiran Komarudin Hidayat di atas itulah yang setidak-setidaknya membuat penulis untuk berpandangan bahwa Pluralisme keyakinan bisa menjadi tantang dan bisa juga menjadi peluang. Tantangan karena, atas azas kerukunan dan sikap ketidakmonopolian soteriologitas yang telah dirintas teolog pluralis maka penginjilan diredefinisikan kembali. Peluangnya adalah dalam hubungan yang dialogis tersebut 'kemungkinan' untuk memperdengarkan berita keselamatan tersebut, terbuka.

Perkembangan gerakan theologi religionum di Indonesia yang pesat ini bukan begitu saja berkembang. Tetapi sudah melalui proses waktu 15-20 tahun terakhir ini. Apalagi semakin gencar-gencarnya konflik antara agama yang terjadi di Indonesia, yang menuntut adanya pertemuan-pertemuan antara para pemimpin agama di Indonesia. Membuat para pemikir kristiani untuk mencoba merefleksikan ulang tentang teologi yang tepat pada konteks Indonesia yang majemuk ini.

\section{E. Misi dan Dialog Antar Agama}

1. Definisi dan Tujuan Dialog Antar Agama

Pluralitas masyarakat ditandai dengan adanya pluralitas agama, budaya, suku dan bahasa. Kehidupan masyarakat yang pluralistis sarat atau rentan konflik baik antar suku, agama maupun ras. Di Indonesia, keteganganketegangan karena agama seringkali terjadi.

120 Komarudin Hidayat, Agama dalam Dialog: Pluralitas Agama dan Masa depan Indonesia (Jakarta: BPK Gunung Mulia, 2001), 204. 
Pemerintah, seperti yang telah diatur dalam Undang-undang Dasar 1945 tentang kebebasan beragama (meskipun dalam tataran praksis masyarakat sering terjadi kebuntuan), toleransi dan dialog antar agama. Dialog merupakan jalan penyelesaian konflik. Karena itu penting untuk membahas dialog sebagai salah satu bagian penting dalam menjaga keharmonisan dalam kemajemukan. Leonard Swidler mendefinisikan dialog sebagai pembicaraan tentang pokok yang dilakukan oleh dua atau beberapa orang yang berbeda pandangan dengan tujuan utama peserta dialog belajar dari yang lainnya sehingga ia dapat berubah sikap dan bertumbuh. ${ }^{121}$

Definisi dialog memang tidak menjadi persoalan. Yang menjadi persoalan adalah bagaimana menyatukan persepsi demi tercapainya tujuan dialog. Di kalangan orang kristiani, perbendaan persepsi tentang dialog sudah tentu terjadi. Bagi Gereja Roma Katolik tujuan dialog adalah untuk belajar saling menghargai kebenaran-kebenaran yang terdapat dalam penganut agama lain dan ditegaskan oleh Banawiratma bahwa bukan hanya sikap saling menghormati melainkan juga untuk mengakui kebenaran dalam agama lain. ${ }^{122}$

Sedangkan bagi gereja Protestan, tujuan dialog adalah untuk memecahkan masalah-masalah sosial sekaligus sebagai penghargaan terhadap eksistensi agama-agama lain demi terciptanya toleransi antar umat beragama. ${ }^{123}$ Berbeda dari Gereja Katolik Roma dan Protestan yang memiliki hakekat dialog yang sama, kaum Injili memahami dialog sebagai saling memahami dan mendengar kepercayaan agama lain. Tujuannya membangun jembatan untuk mengkomunikasikan Injil dengan kasih secara persuasif dan efektif dalam konteksnya. Dalam pemahaman Injili, dialog tidak harus mengorbankan keunikana dalam hal ini finalitas Kristus.

121 Marulak Pasaribu, Agama Suku. Modul Kuliah (Surakarta: STT Berita HidupProgram Pascasarja, 2006), 64.

122 Ibid.

${ }^{123}$ Ibid 
2. Jenis-jenis Dialog

Eric J. Sharpe dalam Netland seperti yang dikutip oleh Marulak Pasaribu, mengklasifikasikan dialog ke dalam empat model dialog, yaitu discursive dialogue, human dialogue, secular dialogue, dan interior dialogue. ${ }^{124}$

1) Discursive Dialogue

Discursive dialogue adalah dialog yang bertujuan untuk belajar tentang agama dan tradisi-tradisi agama lainnya dan sebagai ruang mengklarifikasi hal-hal yang memiliki potensi konflik.

2) Human Dialogue

Human dialogue adalah dialog yang bertujuan bukan hanya mengetahui doktrin-doktrin agama lain dan praktek-prakteknya melainkan sebagai bentuk kepedulian untuk membangun relasi kemanusiaan dengan agama lain

3) Secular Dialogue

Secular dialogue adalah dialog yang menekankan pada pemahaman dan pengenalan ajaran dan praktek-praktek agama lain dengan tujuan membangun persahabatan dengan fokus masalah-masalah kemanusiaan: sosial, ekonomi, dll. Di sini doktrin dan praktek tidak menjadi fokus melainkan asas keadilan. Secara bersama-sama bekerja menuntaskan masalah-masalah sosial yang dihadapi masyarakat.

4) Interior Dialogue

Interior dialogue adalah dialog yang bertujuan untuk terlibat dalam pengalaman-pengalaman yang dimiliki agama lain, misalnya doa bersama dengan menggunakan prakte-prakte berdoa semua agama.

Bahwa teolog-teolog non pluralis (Evangelical) tentu juga telah melakukan evaluasi-evaluasi teologis terutama teologi misi baik metode maupun praktek misi. Dengan tujuan tidak mengulangi kesalahan misi pada masa Zendeling.

124 Ibid 


\section{F. Tanggapan Terhadap Teologi Pluralisme}

Berteologi dalam memandang pluralisme secara berbeda bukan berarti menjadikan ikatan-sejati. Pluralisme agama memang "toleran" karena ingin membangun teologi yang terdengar bersahabat, "semua agama sama-sama benar. Semua agama menyelamatkan". Walaupun demikian teologi pluralisme agama pada dasarnya menyangkali iman Kristen sejati yang kembali pada Alkitab.

Secara kritis pluralisme agama merupakan pendangkalan iman. Orang yang percaya pada teologi pluralisme agama biasanya tidak benar-benar mendasarkan pandangannya atas dasar kitab suci agama yang dianutnya atau tidak benar-benar berteologi berdasarkan sumber utama (kitab suci). ${ }^{125}$ Konsep Kristen yang percaya surga dan neraka, yang percaya akan kelahiran baru dan setiap manusia di selamatkan dengan menerima yesus sebagai Tuhan dan juruselamat, dengan mulut mengaku dan hati menerima Roma 9:10, bahkan perbuatan baik tidak dapat menyelamatkan (Titus 3;5), tentu bertentangan dengan pemeluk islam yang mempercayai surga dan neraka, tetapi terdapat perbedaan konsep dalam melakukan amal.

Bagaimana seharusnya orang Kristen menanggapi pluralism dan menjalankan misi amanat Agung? Sebagai pengikut Kristus, Tuhan Yesus adalah model master pluralism, merespon dengan hikmat sekalipun dalam kesulitan. Yesus sepenuhnya sadar akan semua yang melibatkan salib, penganiayaan, penderitaan, pertentangan, kekacauan, kekerasan dan kerusuhan. Karena itu, ketika muridnya "menghunus pedangnya dan menampar hamba imam besar, memotong telinganya", Ia dengan tenang memerintahkannya untuk mengembalikan pedangnya (Mat. 26:51). Dalam konflik, manusia secara alami cenderung bereaksi agresif tetapi Yesus

${ }_{125}$ Bedjo, Pluralisme Agama dalam perpektif Kristen. Seminar bagi guru-guru Pendidikan Agama Kristen Se-Surabaya di GKI Darmo Satelit, Surabaya pada tanggal 24 Februari 2007. 
mengambil pendekatan radikal - Dia memerintahkan pengikutnya sebagai pembawa damai (Mat. 5:9). Pengikut Kristus harus menjaga kedamaian, antara manusia dan Tuhan dan antara mereka yang berselisih satu sama lain.

Menjadi problem besar bagi kaum Injili yang oleh mereka disebut kaum ekslusivistis ${ }^{126}$ dengan pendekatan eksklusiv konservatif yang berpandangan bahwa "Kristus adalah sumber kebenaran; Kristus adalah Alfa dan Omega kebenaran dan bahwa keselamatan hanya diperoleh di dalam Kristus". Artinya mengenyahkan keyakinan lain sebagai keyakinan yang absurd. Juga kaum inklusivis liberal yang mengakui kekayaan kebenaran agama lain namun memandang kekayaan tersebut sebagai hasil karya penebusan dari Kristus.

Dasar paradigma pluralis yang dibangun dan diperjuangkan Knitter dan rekan-rekannya adalah sebagai langkah menaiki anak tangga eksklusivistis (istilah yang diberikan oleh kaum pluralis kepada kelompok pendukung keunikan Kristen) yang mana Kristus diletakkan sebagai puncak kenyataan atau sebagai the Ultimate Reality dengan The Highst God tanpa nama. Sukseskah Knitter dan rekan-rekannya dalam misi tersebut? Tujuannya menghadirkan bumi yang penuh damai, hidup berdampingan dengan pemeluk keyakinan lain versi Knitter dan rekan-rekan? Mungkinkah mereka masih mengingat realitas yang lain, yakni dosa sebagai penyebab dan bukan soal superioritas berkenaan dengan Kristus sebagai dasar keyakinan? Atau dapatkah "jembatan teologis Rubicon"127 menghantar heterogenitas keyakinan berada di jalan damai? Maksud saya di sini adalah ada kekhawatiran dengan jembatan teologis versi Knitter yang ditawarkan. Ini sebuah harapan utopis manusia yang membangun "teologi kerajaan Allah" dari bawah atau sebuah basilealogi dari bawah yang utopis sebab telah menanggalkan Kristus sebagai Sang Raja. Ini basilealogi yang nihil.

126 Gavin D'Costa, peny., Mempertimbangkan Mitos Keunikan Agama Kristen (Jakarta: BPK Gunung Mulia, 2002).

127 Ibid 
Bukan hanya itu, Knitter dan rekan-rekannya, juga mecoba membangun sebuah soteriosentris dalam agama-agama. Artinya mereka menolak soteriosentris tunggal atau soteriosentris yang ekslusivistis. Tanpa mengurangi rasa kagum pada kaum pluralis yang telah meretas sebuah jalan teologi agamaagama, namun usaha ini sangat antroposentris yakni berpusat pada menyenangkan manusia dengan membangun "shalom" ala manusia.

Seharusnya Knitter menyeberang dari "jembatan teologis Crusis". Memang mungkin sangat metafisis tetapi ini sebuah prinsip dasar bagi basilealogi dan sebagai syarat bila mau membangun teologi kerajaan Allah dari bawah baik dalam tingkat studi teologi maupun dalam tataran praksis teologis yang alkitabiah (bukan menuduh tidak alkitabiah. Karena toh, tetap menggunakan Alkitab).

Dalam pandangan Pluralisme Kristus bukanlah satu-satunya jalan kebenaran atau kebenaran tunggal tidak hanya ditemukan dalam "agama Kristen" dengan dasar kebenaran "Kristus". Pemikiran Pluralisme memang dipengaruhi oleh filsafat "pluralisme" yang menganggap bahwa "kenyataan kebenaran bukanlah tunggal melainkan plural/jamak/banyak". Ini berarti menghapus "absolutisitas kebenaran" dan menekankan "relativitas kebenaran/kebenaran yang relatif". Asumsi yang muncul dari "relativisasi kebenaran" adalah bahwa "tidak semua kebenaran itu harus mutlak benar. Dan semua yang ada di alam "kenyataan/realitas" adalah relatif.

Apakah manusia itu sendiri relatif atau mutlak? Mungkinkah yang relatif bisa menemukan yang mutlak? Jadi bagaimana yang mutlak benar itu dapat diperoleh? Apakah memang kebenaran mutlak itu tidak dapat diketahui dan dicari?. Bila memperhatikan asumsi dari paham relativisme maka "kebenaran dalam iman Kristen" adalah relatif. Dalam hal ini "Kristus yang menjadi dasar kebenaran - Yohanes 3:16 adalah relatif. Dengan demikian Kristus yang dipercayai adalah Kristus yang relatif (Kristologi Relatif); tidak ada lagi Kristus yang unik, Kristus yang eksklusif, agama yang eksklusif, dan iman yang 
eksklusif. Dengan Kristologi Relatif tentu kita sampai pada doktrin Soteriologi Relatif.

Praksisnya, hal-hal dogmatis-eksklusif (agama) yang menimbulkan konflik direduksi dan memandang pada suatu realitas universal, yakni hanya pada Pengada Tertinggi. Hal dogmatis seperti "Kristus jalan satu-satunya kebenaran menuju keselamatan" harus dipikirkan kembali. Kita menyambut baik konsep tersebut dengan teologinya yang memberi pencerahan dan pemikiran baru berkaitan dengan "kesalingpengertian dalam kepelbagaian keyakinan". Namun di sisi lain dan bersamaan, "iman” yang dipegang dengan ciri dan keunikan dari masing-masing penganut agama harus dipikirkan kembali bahkan direduksi. Di tahap ini ada sikap "setuju dalam ketidaksetujuan". Maksudnya, setuju dengan pluralitas agama dan teolog-teolog pluralisme agama telah mengerjakan proyek besar dengan melakukan reinterpretasi tehadap teks biblis untuk menciptakan sebuah teologi baru yang bermanfaat bagi semua orang dan semua umat di segala tempat.

Ketidaksetujuan, dogma-dogma yang sudah ada merupakan ciri khas kristianitas dan menjadi tugasnya untuk menyatakannya. Tugas tersebut adalah tugas perwartaan-kerigmata. Sikap yang berlebihan dari pendukung pluralisme agama cukup riskan. Boleh diumpamakan, menyediakan salib untuk menyalibkan diri sendiri. Dan apakah proyek ini telah menyentuh masa akar rumput umat - tataran praksis? Ataukah hanya proyek akademis teologis semata?

Pusat metafisika Kristen adalah pada Allah di dalam Kristus. yakni untuk mencari dan mengenal realitas Ter- tinggi dan terakhir, yakni Tuhan (yang saya tuju adalah TUHAN dalam Alkitab. Namun, ada yang mempertanyakan apakah Tuhan orang Kristen adalah Tuhan yang universal. Mengenai hal ini masih ada pro dan kontra antara teolog-teolog Pluralis, dengan teologi agama-agama/teologi abu-abu/teologia religionum mereka, yang 'kontra' dengan teolog-teolog Injili yang memegang Inerensi Alkitab). Para teolog 
Pluralis mencoba menghadirkan suatu teologi agama-agama dengan sistem dialogis. Adanya kepincangan (fatal) dalam teologi agama-agama yakni tidak diakuinya finalitas Yesus. Jika tidak mengakui finalitas Yesus maka kepercayan / iman Kristen sama dengan "kepercayaan" yang lain. Kekristenan berakar pada kematian dan kebangkitan Kristus. Seperti esay-esay dalam buku Mitos Keunikan Agama Kristen, kaum pluralis mencoba menempatkan Yesus di luar wacana teologi mereka. Jika Yesus tidak lagi menjadi central teologi Kristen maka teologi atau ajaran-ajaran Kristen tidak menjadi unik lagi sebab keunikan agama Kristen (teologi Kristen) justru ada pada kematian dan kebangkitan Kristus; bahkan tidak mengakui finalitas Alkitab. Artinya bahwa ada kebenaran-kebenaran lain di luar Alkitab (kanonitas). Sehingga sistem hermeneutika para teolog pluralis selalu berangkat dari konteks kepada teks (Alkitab) tidak lagi berangkat dari teks (Alkitab) kepada konteks. Dapat dibayangkan bila kajian kita tidak berangkat dari teks Alkitab. Padahal Alkitablah yang harus menjadi bahan bacaan dan pokok kajian pertama.

Pluralisme agama dalam pengertian teologi agama-agama harus dimengerti dan di hayati masing masing pemeluk, tetapi di lihat dari segi iman kristiani dan berdasarkan epistemologi Alkitab, Orang Kristen perlu berani mengakui perkataan Yesus "Akulah jalan dan kebenaran dan hidup. Tidak ada seorangpun yang datang kepada Bapa, kalau tidak melalui Aku." Konsisten iman perlu di pertahankan tetapi pengertian pluralisme agama secara sosial bisa di terima. 


\section{DAFTAR PUSTAKA}

Aritonang, Jan S. A Glimpse of plurality of Religious and Faiths in Indonesia. Asian Society of Misiology, 2018.

Aritonang, Jan, S. Berbagai Aliran di dalam dan di Sekitar Gereja. Jakarta: BPK Gunung Mulia, 2012.

Aritonang, Jan S. A History of Christianity in Indonesia: Studies in Christian Mission. Ed. Jan S. Aritonang dan Karel Steenbrink. Boston: Brill, 2008.

Aritonang, Jan S. Sejarah Perjumpaan Kristen dan Islam di Indonesia. Jakarta: BPK Gunung Mulia, 2004.

Audi, Robert. Agama dan Nalar Sekuler dalam Masyarakat Liberal. Yokyakarta: UII Pres, 2002.

Aurelius, Marcus. https://www.goodreads.com/author/quotes/17212

Bagus, Lorens. Kamus Filsafat. Jakarta: Gramedia, 2007.

Baker, Anton dan Achmad C. Zubair. Metodologi Penelitian Filsafat. Yogyakarta: Kanisius, 2005.

Bavink, J.H. An Introduction to the Science of Missions. New Jersey: P\&R Publishing, n.d.

Becker, Dieter. Pedoman Digmatika-Suatu Kompendium Singkat. Jakarta: BPK Gunung Mulia,2001.

Bedjo. Pluralisme Agama dalam Perpektif Kristen. Seminar bagi guru-guru Pendidikan Agama Kristen Se-Surabaya di GKI Darmo Satelit, Surabaya pada tanggal 24 Februari 2007.

Boiliu, Noh, Ibrahim. "Kesinambungan Panggilan Misionaris Bangsa Israel dengan Panggilan Pelayanan Misi dan Pemuridan.” Jurnal Te Deum 4, no. 2 (Juni 2015): 209-223.

. "Perjumpaan Rasul Paulus Dengan Kristus Pneumatis Sebagai Titik Kulminasi Religiusitasnya", Jurnal Stulos 3, no. 13 (April 2014), 97-118.

"Religiusitas Eksistensial Manusia." Jurnal Te Deum 2, no. 2 (Juni 2013): 247-261.

"Penerapan Hermeneutika Fenomenologis pada Penelitian Teologi: Diskursus tentang Metode Ilmiah Teologi.” Jurnal Stulos 12, no. 2 (2013): 245-266.

"Manusia dan Pluralisme Keyakinan di Indonesia." Jurnal Stulos 10, no. 1, (2011), 53-71.

Copleston, Frederick. Â History of Philosophy: Fichte to Niestzsche. London: Search Press, 1963.

Cremers, Agus (Alih) dan A. Spratiknya (edit). Teori-teori Perkembangan Kepercayaan. Karya-karya Penting James W. Fowler, Yogyakarta: Kanisius, 1995.

Dagun, Save, M. Filsafat Eksistensialisme. Jakarta: Rineka Cipta, 1990. 
Dana, John, S. Teologi Perjanjian Lama 1. Catatan Kuliah. Surakarta: STT Berita Hidup, 2005.

D’Costa Gavin. Peny. Mempertimbangkan Kembali Keunikan Agama Kristen. Jakarta: BPK Gunung Mulia, 2002.

Dhavamony, Mariasusai. Fenomenologi Agama. Yogyakarta: Kanisius, 2010.

Enns, Paul. The Moody Hand Book of Theology. Diterjemahkan oleh Rahmiati Tanudjaja. Malang: Literatur SAAT, 2003.

Fox, Jonatahan. Ethnic Minorities and the Clash of Civilizations: A Quantitative Analysis of Huntington's. Thesis. Cambridge: Cambridge University Press, 2002.

Gandhi, Mahatma. Seven Deadly Sins. www.mkgandhi.org. Diakses, Juli 2018.

Gelder, Craig, van dan Dwight J. Zscheile. The Mission Church in Perspective: Mapping Trends and Shapping the Conversation. USA: Baker Academi, 2017.

Grazia, Alfred de. The Divine Succession: A Science Of Gods Old And New. New York: Multiprint Company, 1983.

Harold, Kock. An Introduction to Christian Missions. USA: Moody Press, 1974.

Hadiwiyono, Harun. Iman Kristen. Jakarta : BPK Gunung Mulia, 1992.

Hardiman, F. Budi. Melampaui Positivisme dan Modernitas: Diskursus Filosofis tentang Metode Ilmiah dan Problem Modernitas. Yogyakarta: Kanisius, 2007.

Hardjana, Agus, M. Religiositas, Agama dan Spiritualitas. Yogyakarta: Kanisius, 2009.

Heath, Stanley. Filsafat Apologetika. Catatan Kuliah. Surakarta: STT Berita Hidup, 2007.

Hidayat, Komarudin. Agama dalam Dialog: Pluralitas Agama dan Masa depan Indonesia. Jakarta: BPK Gunung Mulia, 2001.

Kane J. Herbert. The Christian World Mission. Today and Tomorrow. Michigan: Baker Book House, 1986.

Jaiz, Hartono, Ahmad. Aliran \& Paham Sesat di Indonesia. Jakarta: Pustaka AlKautsar, 2002.

Knitter, Paul. Satu Bumi Banyak Agama. Jakarta: BPK Gunung Mulia, 2006.

Kong, Wong, Kim. Human Rights in Religion Coexistence among followers of Different Religion. DOHA: Interfaith Dialogue Conference, 20-21 February 2018.

Lalsangkima, Pachuau dan Jørgensen Knud. Witnessing to Christ in a Pluralistic World Christian Mission Among Other Faiths. Edinburg: Regnum, 2010.

Lefebure, Leo, De. Penyataan Allah, Agama dan Kekerasan. Jakarta: BPK Gunung Mulia, 2007.

Mujihburrahman. Feeling Threatened Muslim-Christian in Indonesia New Order. Amsterdam: Amsterdam University Press, 2006.

Oden, Greg. Pemuridan yang Mengubahkan. Surabaya: PERKANTAS, 2014.

Ostina, Panjaitan. Manusia sebagai Eksistensi: Menurut Pandangan Soren A. Kierkegaard. Jakarta: Yayasan Sumber Agung, 1996.

Payne, J. D. Discipleship in Church Planting: Some Guidelines to Move Us Forward. USA: Good News Publisher, 2011. 
Peursen, C. A. Van. Strategi Kebudayaan. Yogyakarta: Kanisius, 2001.

Putman, Jim. Building Churches that Make Disciples. Colorado: NavPress, 2010.

Rad, Von. The Old Testament Library. Philadelphia: Wesminister Pres, $1956 .$.

Rapar, Jan, Hendrik. Pengantar Filsafat. Yogyakarta: Kanisius, 2005.

Renckens, Henry. The Religion of Israel. New York: Seed and Ward, 1965.

Riderbos, Herman. Paulus: Pemikiran Utama Theologinya. Surabaya: Momentum, 2008.

Ryrie, Charles, C. Teologi Dasar. Panduan Populer untuk Memahami Kebenaran Alkitab. Yogyakarta: Yayasan Andi, 1991.

Sairin, Wenata, dan J.M, Pattiasina. Hubungan Gereja dan Negara dan Hakhak Asasi Manusia. Jakarta: BPK Gunung Mulia,1999.

Schnabel, Eckhard, J. Paul the Missionary. Realitas, Strategis dan Metode. Illionis: Interversity Press, 2008.

Simanjuntak, Togi. The Art Of Mentoring. Jakarta: Metanoia, 2012.

Sinaga Martin, Lukito. Meretas Jalan Teologi Agama-agama di Indonesia. Jakarta: BPK Gunung Mulia.

Siswanto, Joko. Metafisika Sistematik. Yogyakarta: Taman Pustaka Kristen, 2004.

Smith, Morton. The Church and covenant Theology. https://www.apuritansmind.com. Diakses, 26 Juni 2016.

Smith, Ralph, A. The Covenantal Structure of the Bible: Introduction to the Bible. http://www.berith.org/essays/bib/. Diakses 26 Juni 2016.

Smith, Wilfred C. Memburu Makna Agama. Bandung: Mizan, 2004.

Suseno, Franz, Magnis. Kuasa dan Moral. Jakarta: Gramedia, 2001.

Suseno, Franz, Magnis. Etika Dasar. Yokyakarta: Kanisius, 2002.

Tomatala, Yakub. Penginjilan Masa Kini. Jilid 2. Malang: Gandum Mas, 1998.

Tong, Stephen. Teologi Penginjilan. Surabaya: Momentum, 2007.

Whitehead, Alfred, North. Mencari Tuhan Sepanjang Zaman: Dari AgamaKesukuan Hingga Agama Universal. Diterjemahkan oleh Alois Agus Nugroho. Bandung, Mizan, 2009.

Departeman Agama RI, Bingkai Teologi: Kerukunan Hidup Umat Beragama Menurut Pandangan Kristen Protestan. Jakarta: Departemen Agama RI, 1997. 


\section{TENTANG PENULIS}

Fransiskus Irwan Widjaja adalah Doctor of Theology Konsentrasi Misi STT Real Batam, PhD candidate dari BIU Singapore, Alumni Oklahoma State University, 1989, Stillwater USA, penulis juga pengajar Pasca Sarjana (S2 \& S3), menggembalakan GBI My Home Rawasari di Tanjung Pinang, Pastor in Charge untuk gereja-gereja misi di Kepulauan Riau dan Asia Tenggara, World Mission Director dari BCS Singapore (2001-sekarang), SEACPN (South East Asia Church Planting Network) Fasilitator 2013-2015, Executive Committee GCPN London (Global Church Planting Network), 2014 - sekarang, Haggai Institute Faculty, dan sekarang menjabat Ketua Yayasan Transformasi Indonesia Cerdas (2017- sekarang).

Noh Ibrahim Boiliu menyelesaikan pendidikan Sarjana Teologi dari STT Sangkakala Salatiga (2004), Magister Theologi Konsenterasi Filsafat Agama dari STT Berita Hidup Solo (2007), dan sedang studi lanjut Program Doktoral di STT Cipanas dengan konsenterasi Pendidikan Agama Kristen. Ia juga menjadi dosen tetap untuk mata kuliah Perjanjian Lama dan Filsafat pada Program Studi Pendidikan Agama Kristen, Fakultas Keguruan dan Ilmu Pendidikan Kristen, Universitas Kristen Indonesia Jakarta. Juga menjadi dosen tidak tetap untuk mata kuliah Filsafat dan Filsafat Ilmu di STT Bethel The Way Jakarta dan STT Real Batam. Buku-buku yang telah diterbitkan antara lain: Tuhan dan Manusia dalam Pemaknaan Hidup (STTB The Way, 2012), Teologia Perjanjian Lama: Kejadian-Ester (STT Bethel Samrinda, 2015), Filsafat Pendidikan Kristen (UKI Press, 2017), dan Menjadi Manusia Otentik (Hegel Pustaka, 2018). 